INTERNATIONAL MONETARY FUND

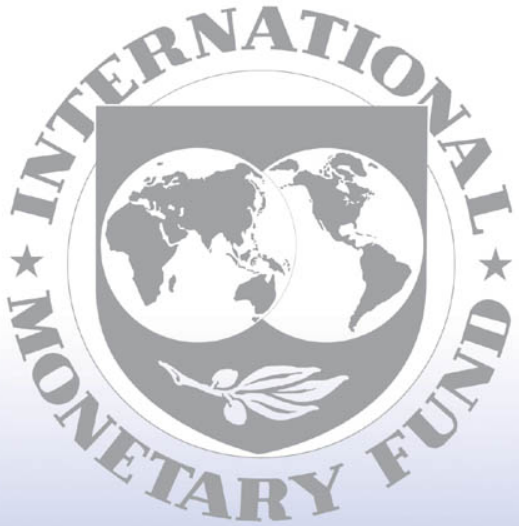

Staff

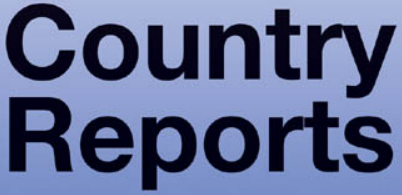




\section{Haiti: Enhanced Initiative for Heavily Indebted Poor Countries- Completion Point Document}

This paper was prepared by staffs of the International Monetary Fund and the World Bank in connection with the Executive Board's consideration of Haiti's progress under the Enhanced Initiative for Heavily Indebted Poor Countries. It is based on the information available at the time it was completed on June 15, 2009. The views expressed in this document are those of the staff team and do not necessarily reflect the views of the government of Haiti or the Executive Board of the IMF.

The policy of publication of staff reports and other documents by the IMF allows for the deletion of market-sensitive information.

Copies of this report are available to the public from

International Monetary Fund • Publication Services

700 19th Street, N.W. • Washington, D.C. 20431

Telephone: (202) 623-7430 • Telefax: (202) 623-7201

E-mail: publications@imf.org • Internet: http://www.imf.org

\section{International Monetary Fund Washington, D.C.}


INTERNATIONAL DEVELOPMENT ASSOCIATION AND

THE INTERNATIONAL MONETARY FUND

HAITI

Enhanced Heavily Indebted Poor Countries (HIPC) Initiative

Completion Point Document and

Multilateral Debt Relief Initiative (MDRI)

Prepared by Staffs of the International Monetary Fund and the International Development Association

Approved by Pamela Cox and Otaviano Canuto (IDA)

Gilbert Terrier and Dominique Desruelle (IMF)

June 15, 2009

(CInternational Monetary Fund. Not for Redistribution 


\section{Table of Contents}

Abbreviations and Acronyms

Executive Summary .$\underline{5}$

I. Introduction $\underline{8}$

II. Assessment of Requirements for Reaching the Completion Point ..................................... 9

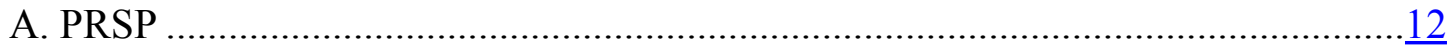

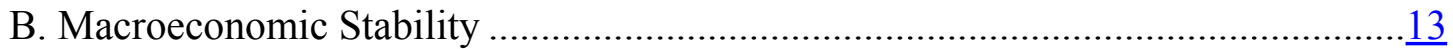

C. Public Expenditure Management and Governance ……………….......................

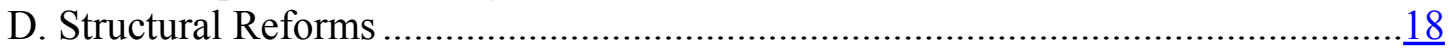

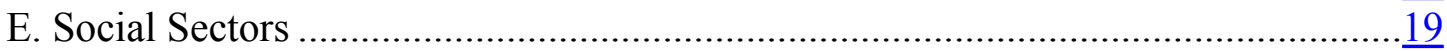

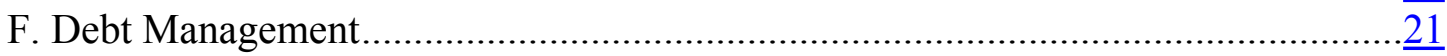

III. Debt Sustainability After HIPC and MDRI Assistance...........................................22

A. Updated Data Reconciliation and Revision of Assistance......................................22

B. Status of Creditor Participation in the Enhanced HIPC Initiative...........................23

C. Debt Outlook after HIPC Assistance and Consideration for Exceptional

Topping-Up of HIPC Assistance ………………….................................................

D. Creditor Participation in the Multilateral Debt Relief Initiative ............................27

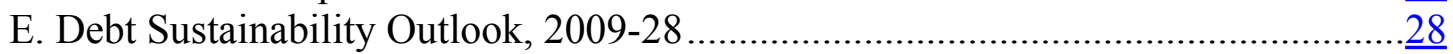

F. Sensitivity Analysis and Long-Term Debt Sustainability ………………………...

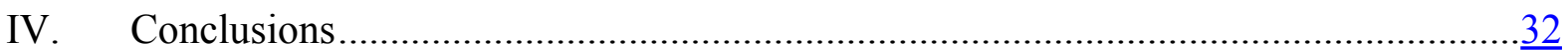

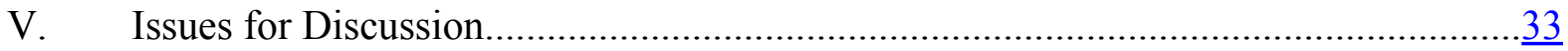

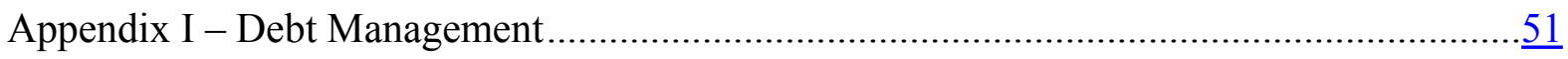

Appendix II - Debt Sustainability Analysis (LIC DSF Methodology) ………………….......

Text Tables

1. Selected Macroeconomic Indicators, 2002-09...........................................................

2. Breakdown in the increase of NPV of Debt-to-Export Ratio (end September-2008) ......27

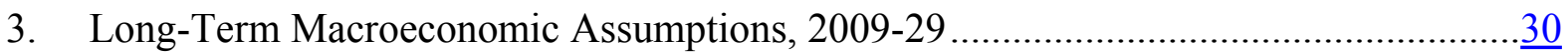

Figures

1. Composition of the Stock of External Debt by Creditor Group .......................................

2. External Debt and Debt Service Indicators for Medium- and Long-Term Public Sector

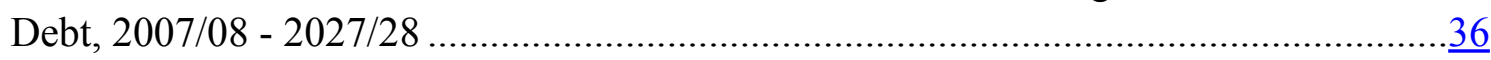

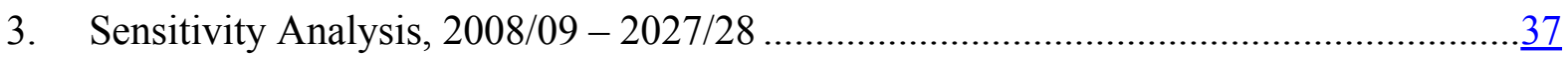


Boxes

1. Status of Floating Completion Point Triggers …........................................................

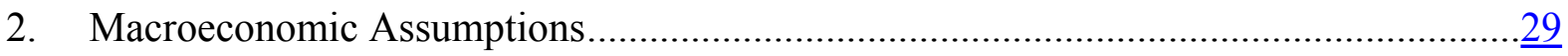

Tables

1. Revised Nominal Stocks and Net Present Value of Debt at Decision Point by Creditor

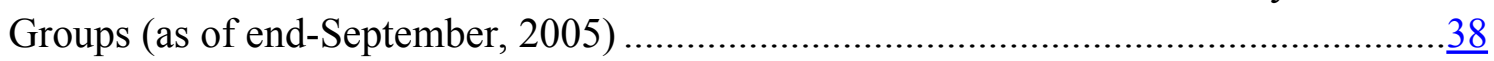

2. Estimated Assistance at Decision Point (Amended) .......................................................39

3. Comparison of Discount Rate and Exchange Rate Assumptions ................................... 40

4. Status of Creditor Participation Under the Enhanced HIPC Initiative .............................41

5. Nominal and Net Present Value of External Debt outstanding at End-September 2008. $\underline{42}$

6. Net Present Value of External Debt, 2007/08 - 2027/28 …….....................................

7. External Debt Service After Full Implementation of Debt-Relief Mechanisms, 2008/09 2027/28

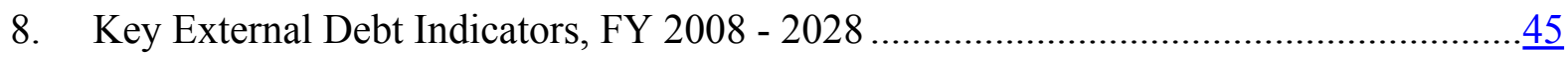

9. Sensitivity Analysis, 2008/09 - 2027/28 ……....................................................

10. Delivery of IMF Assistance under the Enhanced HIPC Initiative, 2006/07 - 2016/17 ..4 $\underline{47}$

11. Delivery of World Bank HIPC Assistance and MDRI, 2005/06 - 2044/45 …….............48

12. Paris Club Creditors' Delivery of Debt Relief Under Bilateral Initiatives Beyond the HIPC Initiative

13. HIPC Initiative: Status of Country Cases Considered Under the Initiative, March 31, 2009 


\section{Abbreviations ANd ACronyms}

\begin{tabular}{|c|c|c|c|}
\hline AIDS & $\begin{array}{l}\text { Acquired Immune Deficiency } \\
\text { Syndrome }\end{array}$ & I-PRSP & $\begin{array}{l}\text { Interim Poverty Reduction Strategy } \\
\text { Paper }\end{array}$ \\
\hline APN & Ports Authority & JSAN & Joint Staff Advisory Note \\
\hline APR & Annual Progress Report & LIC & Low-Income Countries \\
\hline ART & Anti-Retroviral Therapy & MDB & Multilateral Development Bank \\
\hline ASYCUDA & Automated System for Customs Data & MDG & Millennium Development Goal \\
\hline BCG & Bacillus Calmette-Guérin & MDRI & Multilateral Debt Relief Initiative \\
\hline BRH & $\begin{array}{l}\text { Banque de la République d'Haïti } \\
\text { (Central Bank of Haiti) }\end{array}$ & MEF & Ministry of Economy and Finance \\
\hline CEMLA & $\begin{array}{l}\text { Center for Latin American Monetary } \\
\text { Studies }\end{array}$ & MENJS & $\begin{array}{l}\text { Ministry of Education, Youth, and } \\
\text { Sports }\end{array}$ \\
\hline CIDA & $\begin{array}{l}\text { Canadian International Development } \\
\text { Agency }\end{array}$ & MINUSTAH & $\begin{array}{l}\text { United Nations Stabilization Mission in } \\
\text { Haiti }\end{array}$ \\
\hline CNMP & $\begin{array}{l}\text { National Commission for Public } \\
\text { Procurement }\end{array}$ & NPV & Net Present Value \\
\hline CPI & Consumer Price Index & OPEC & $\begin{array}{l}\text { Organization of Petroleum Exporting } \\
\text { Countries }\end{array}$ \\
\hline CSCCA & $\begin{array}{l}\text { Cour Supérieure des Comptes et du } \\
\text { Contentieux Administratif (Supreme } \\
\text { Audit Institution) }\end{array}$ & PAHO & Pan-American Health Organization \\
\hline DSA & Debt Sustainability Analysis & PEM & Public Expenditure Management \\
\hline DHS & Demographic and Health Survey & PEMFAR & $\begin{array}{l}\text { Public Expenditure Management and } \\
\text { Financial Accountability }\end{array}$ \\
\hline DMFAS & $\begin{array}{l}\text { Debt Management Financial and } \\
\text { Analysis System }\end{array}$ & PRGF & Poverty Reduction and Growth Facility \\
\hline DPT & Diptheria, Pertussis and Tetanus & PRSP & Poverty Reduction Strategy Paper \\
\hline GDP & Gross Domestic Product & SDR & Special Drawing Rights \\
\hline GNI & Gross National Income & SYSDEP & $\begin{array}{l}\text { Automated System for Budget } \\
\text { Management }\end{array}$ \\
\hline EDH & Electricity Utility & ULCC & Anti-Corruption Unit \\
\hline FER & Road Maintenance Fund & UNDP & $\begin{array}{l}\text { United Nations Development } \\
\text { Programme }\end{array}$ \\
\hline GF & $\begin{array}{l}\text { Global Fund to Fight AIDS, } \\
\text { Tuberculosis and Malaria }\end{array}$ & & \\
\hline HIPC & Heavily Indebted Poor Countries & UNAIDS & $\begin{array}{l}\text { United Nations Programme on } \\
\text { HIV/AIDS }\end{array}$ \\
\hline HIV & Human Immune-deficiency Virus & UNCTAD & $\begin{array}{l}\text { United Nations Conference on Trade and } \\
\text { Development }\end{array}$ \\
\hline HOPE Act & $\begin{array}{l}\text { Hemispheric Opportunity through } \\
\text { Partnership Encouragement Act }\end{array}$ & & \\
\hline IBRD & $\begin{array}{l}\text { International Bank for Reconstruction } \\
\text { and Development }\end{array}$ & UNGASS & $\begin{array}{l}\text { United Nations General Assembly } \\
\text { Special Session }\end{array}$ \\
\hline IDA & International Development Association & UNICEF & United Nations Childrens Fund \\
\hline IADB & Inter-American Development Bank & WHO & World Health Organization \\
\hline IMF & International Monetary Fund & & \\
\hline
\end{tabular}




\section{EXECUTIVE SUMMARY}

In November 2006, the Executive Boards of the International Development Association (IDA) and the International Monetary Fund (IMF) agreed that Haiti had met the requirements for reaching the decision point under the Enhanced Heavily Indebted Poor Countries (HIPC) Initiative. The amount of debt relief to be committed at the decision point was US\$140.3 million in end-September 2005 net present value (NPV) terms (US\$212.9 million in nominal terms) in order to bring the NPV of debt to 150 percent of exports. This relief represented a common reduction factor of 15.1 percent for all creditors.

- In the opinion of IDA and IMF staffs, Haiti has made satisfactory progress in implementing the reforms specified for reaching the completion point. The first full PRSP was presented to the IDA and IMF Boards in November 2007 and the first Annual Progress Report was submitted in April 2009. Implementation has been satisfactory, as indicated in the Joint Staff Advisory Note (JSAN). Despite a series of adverse exogenous shocks in 2008 (high commodity prices and four back-to-back hurricanes and tropical storms), Haiti has maintained a stable macroeconomic environment, as evidenced by performance under its PRGF-supported program. IMF staff will recommend completion of the fifth PRGF review in conjunction with consideration of the HIPC completion point. The implementation of other triggers has been mostly satisfactory. Overall, the authorities have implemented 11 out of 15 triggers and are requesting waivers for the remaining four, based on the good progress achieved so far.

- Substantial advances have been made toward meeting the four triggers not fully implemented, and the authorities are committed to further progress in the coming months. These triggers relate to publication of audited government accounts; implementation of a new procurement law; education funding, teacher training, and school inspections; and increasing immunization rates. Audited government accounts have been submitted and will be published once the audited accounts have been reviewed by Parliament. Haiti's Parliament passed a new procurement law in June 2009 which is in line with international best practices. This law constitutes a solid legal basis for the establishment of a modern and transparent procurement system. In recent years, the government also took a number of steps to strengthen procurement practices in advance of the passage of the law. Following the adoption of the 2005 decree to strengthen the previous procurement law, the National Commission for Public Procurement (CNMP) was created, and standard bidding documents and manuals were provided to government procurement staff to support the application of standardized procedures by purchasing agencies. On education, the overall spending target was narrowly missed, reflecting the need to respond to emergencies in 2008, but a majority of education spending was devoted to primary schooling as intended. 
Approximately 2,500 teachers are now being trained and are expected to graduate in 2010. Steps have been taken to increase school inspections, including with a doubling of school inspectors. On health, immunization rates for Diptheria, Pertussis and Tetanus (DPT3) and measles have increased, but the Bacillus Calmette-Guérin (BCG) rate has remained largely unchanged, though from an initially high level.

Small changes to debt and export data do not warrant a revision in the amount of HIPC debt relief. There have been minor upward revisions to the decision point debt stock and the goods and services export figures used to calculate HIPC assistance at decision point. These changes would imply a downward revision in HIPC relief, but since the implied reduction is equal to the threshold for such adjustments (1 percent change in the targeted NPV of debt following HIPC relief), no change in the amount of HIPC relief is proposed and the amount of relief to be provided will remain US\$140.3 million in NPV terms.

- Creditors accounting for 96 percent of total HIPC assistance in NPV terms have given satisfactory assurances of their participation in the Enhanced HIPC Initiative. All Paris Club and multilateral creditors have confirmed their participation. The staffs have encouraged the authorities to work toward reaching agreements with two remaining bilateral creditors.

- Staffs are of the view that Haiti does not meet the requirements for exceptional topping-up under the Enhanced HIPC Initiative. Although the NPV of Haiti's debt-to-exports ratio after HIPC relief would be worse than anticipated at decision point, after taking into account additional bilateral relief the NPV of debt-to-exports would be just below the HIPC threshold of 150 percent at completion point. After some deterioration, this ratio would return below the threshold in the medium-term (after FY 2015).

Upon reaching the completion point, Haiti would also qualify for additional debt relief under the Multilateral Debt Relief Initiative (MDRI). Debt relief under the MDRI would cover all remaining debt service obligations on eligible credit balances to IDA and the Inter-American Development Bank (IADB). MDRI relief net of HIPC assistance would lead to a nominal reduction in the stock of debt owed to IDA of US\$446 million and to the IADB of US\$395 million.

- Haiti's debt burden will decrease significantly after it receives Enhanced HIPC assistance and MDRI relief. HIPC and MDRI assistance would bring the NPV of debt-to-exports ratio in FY 2009 from 169 percent (taking only traditional relief into account) to 79 percent. The NPV of debt-to-exports ratio would rise to 111 percent in FY 2014 before declining in subsequent years. 
- While Haiti's debt ratios would be much more manageable after HIPC and MDRI relief, Haiti's risk of debt distress would remain high. This reflects recent and near-term borrowing requirements, a relatively weak export base, and the need for further policy and institutional strengthening to enhance debt-carrying capacity. Sensitivity analysis shows the potential for significant deterioration in debt ratios under adverse circumstances such as growth or export shocks. Taken together, these factors underscore the importance of maximizing grant assistance and borrowing only on highly concessional terms.

- The staffs recommend that the Executive Directors of IDA and the IMF approve the completion point for Haiti under the Enhanced HIPC Initiative. 


\section{INTRODUCTION}

\section{This paper discusses the progress made by Haiti under the Enhanced Heavily} Indebted Poor Countries (HIPC) Initiative. It recommends that the Executive Directors of the International Development Association (IDA) and the International Monetary Fund (IMF) approve the completion point for Haiti under the Enhanced HIPC Initiative. In the view of the staffs, Haiti has made satisfactory progress in achieving the completion point triggers, despite a challenging environment during the HIPC interim period, marked by major natural disasters, the food and fuel crisis, difficult political conditions and the global economic downturn. Haiti has fully implemented the completion point triggers on preparing and implementing a Poverty Reduction Strategy Paper (PRSP), maintaining a stable macroeconomic environment, tracking poverty-reducing spending and publishing quarterly reports, aligning public spending with PRSP priorities, enacting and reporting on implementation of an asset declaration law, strengthening tax and customs administration, improving debt management and reporting, establishing a financing mechanism to allow 50,000 additional children to attend school, and approving an HIV/AIDS prevention and treatment plan. Four of the 15 triggers have not been fully implemented, specifically, the triggers on submitting and publishing audited government accounts; implementing the new public procurement law; increasing education spending, training new teachers, and inspecting schools; and increasing immunization rates for DPT3, BCG and measles. The authorities are requesting waivers for the four triggers not fully implemented on the basis of progress achieved so far.

\section{In November 2006, the Executive Boards of IDA and the IMF agreed that Haiti had met the requirements for reaching the decision point under the Enhanced HIPC} Initiative. ${ }^{1}$ Directors welcomed the progress made by Haiti in restoring political and economic stability and solid performance under successive programs supported by the Fund's Emergency Post-Conflict Assistance, under which macroeconomic stability was restored through fiscal discipline and improved economic governance. In view of Haiti's high debt burden, Executive Directors agreed that a total of US\$140.3 million in NPV terms (US\$212.9 million in nominal terms) would be required to reduce the NPV of debt to 150 percent of exports. This relief represented a common reduction factor of 15.1 percent for all creditors. At the same time, interim relief was granted by the Boards of IDA and the IMF until the country reached its floating completion point. Interim assistance has also been provided by the IADB and the Paris Club. Executive Directors determined that the completion point would be reached when Haiti complied with the triggers set out in Box 2 of the decision point document and satisfactory assurances of other creditors' participation in the Enhanced HIPC Initiative were received.

\footnotetext{
${ }^{1}$ See Haiti-Enhanced Initiative for Heavily Indebted Poor Countries—Decision Point Document (IDA/R20060206 and IMF Country Report No. 06/440 .
} 
3. This document is organized as follows: Section II assesses Haiti's performance in meeting the requirements for completion point under the Enhanced HIPC Initiative. Section III provides an updated debt sustainability analysis (DSA), including the status of creditor participation, delivery of debt relief under the Enhanced HIPC and MDRI Initiatives, and consideration of topping-up assistance under the Enhanced HIPC Initiative. Section IV summarizes the main conclusions and Section $\mathrm{V}$ presents issues for discussion by the Boards of IDA and the IMF.

\section{ASSESSMENT OF REQUiREMENTS FOR REACHING THE COMPLETION POINT}

4. Haiti has made good progress in meeting the completion point triggers. The conditions for reaching the floating completion point triggers, as spelled out in Box 2 of the decision point document and below in Box 1, relate to:

- $\quad$ Preparation of a full PRSP and satisfactory implementation for at least one year, as evidenced by an Annual Progress Report.

- Maintenance of macroeconomic stability as evidenced by satisfactory performance under the PRGF-supported program.

- $\quad$ Strengthened public finance management and governance through better expenditure tracking and alignment with the PRSP, auditing of public accounts and greater transparency, improved procurement practices, and asset declarations.

- Strengthened tax administration and policy through improved customs controls and tracking of taxpayers.

- Education - increased primary education funding, school enrollment, teacher training, and school inspections.

- Health - greater immunization coverage and an HIV/AIDS prevention and treatment strategy.

- Improved debt management capacity. 


\section{Box 1. Status of Floating Completion Point Triggers}

\section{Triggers}

1. PRSP: Preparation of a full PRSP through a participatory process and satisfactory implementation of its recommended actions for at least one year, as evidenced by an Annual Progress Report submitted by the Government to satisfaction of IDA and the IMF.

\section{Progress}

Implemented. A full PRSP drafted in a participatory process was approved by the Government and submitted to the International Development Association (IDA) and the International Monetary Fund (IMF) on November 30, 2007. The first Annual Progress Report (APR) was submitted to IDA and the IMF on April 23, 2009. The JSAN of the APR is being presented to IDA and the IMF Boards together with this document.

2. Macroeconomic stability: Maintenance of macroeconomic stability as evidenced by satisfactory performance under the PRGF-supported program.
Implemented. Macroeconomic developments since the decision point have been broadly satisfactory. The PRGF-supported program has remained on track. The fourth review of the program was completed on February 11, 2009. IMF staff will recommend that the fifth PRGF review be completed together with the discussion of the HIPC completion point.

\section{Public expenditure management:}

(a) Adoption of an automated mechanism to track public expenditures for poverty reduction on the basis of existing expenditure classification, publication of quarterly reports on these expenditures executed over a period of at least six months preceding completion point.

(b) Alignment of public spending priorities with the I-PRSP, and, when completed, the PRSP, reflecting emphasis on propoor growth.

(c) Up-to-date preparation of Government accounts by the MEF and their annual audit by the supreme audit institution (CSCCA), submission to Parliament and publication of audited Government accounts following generally accepted audit standards and legally mandated timetable.

(d) Adoption and satisfactory implementation of a new public procurement law, in line with international best practice. Compliance by all Government purchasing agencies evidenced by independent audit of contracts above US\$1 million equivalent and also of a representative random sample of all other Government contracts, awarded during the 6 months preceding the audit.

(e) Adoption of a law on asset declaration and submission to the CSCCA and to the Parliamentary ethics and anti-corruption commissions of at least one annual compliance report on the monitoring of asset declarations covering the preceding year.
Implemented. Poverty-reducing spending is being tracked based on existing classifications. Quarterly reports published through December 2008 are available on www.mefhaiti.gouv.ht, with the most recent report covering the period October 2008-March 2009 also on the website.

Implemented. Budget allocations and public spending have been aligned with PRSP priorities, as discussed in the APR and JSAN.

Substantially implemented. The audited Government accounts for FY 2006 and FY 2007 have been completed and submitted to the Parliament on January 10, 2009. The accounts will be published in the official gazette after review by Parliament. The FY 2008 accounts have been submitted to the CSCCA.

Partially implemented. Haiti's Parliament passed a new procurement law in June 2009. The law constitutes a solid legal basis for the establishment of a modern and transparent procurement system. Full compliance was not achieved because of obstacles encountered in submitting the draft procurement law to Parliament, including the five-month political stalemate in 2008. Despite the absence of a consistent legal framework for procurement, partial adoption of improved procedures by some key government entities has occurred.

Implemented. The Law has been in effect since February 2008. A report on the first year since the law was enacted was submitted to the Court of Accounts and Parliament in April 2009.

4. Structural Reforms: Strengthen tax administration and policy by: 


\section{Box 1. Status of Floating Completion Point Triggers}

\section{Triggers}

Haïtien, Gonaives, Saint Marc, Miragoane, Malpasse, Ouanaminthe and Belladere, including by installing the automated system for customs data (ASYCUDA).

\section{Progress}

Prince, Cap Haïtien, Gonaives, Saint Marc, Miragoane, Malpasse, Ouanaminthe and Belladere.

Implemented. The central taxpayer file is being used for all taxes throughout Port-au-Prince metropolitan zone and registering in it all the taxpayers identified in the tax centers of Cayes, Miragoane, Saint Marc, Port de Paix, Cap Haïtien and Fort Liberté.

\section{Social Sectors:}

\section{(i) Education:}

(a) Adoption and satisfactory implementation of a public financing mechanism to help poor families pay for costs of school fees in non-public schools to allow enrollment of an additional 50,000 out-of-school children in primary school as evidenced by the results of an independent audit of schools receiving public transfers.

(b) Actual recurrent expenditures for education reach at least 21 percent of actual total recurrent Government spending, of which at least 50 percent is spent on primary education, over the 12 months preceding completion point, enabling inter alia the training of 2,500 new primary teachers (at least 1 year) and on average two visits per year of all primary schools by the Ministry of Education, Youth, and Sports (MENJS) inspectors.
Implemented. A satisfactory mechanism transferring subsidies to schools has been established, and is now supporting an estimated 80,000 children, far exceeding the target of 50,000 children. Based on preliminary results as of mid-June 2009, the independent audit of schools receiving public transfers verified transfers for over 50,000 children.

Substantially implemented. Spending for FY 2007 increased to 19.4 percent and budget allocations for FY 2008 reached 20.3 percent, just short of the 21 percent. Basic education expenditures did account for 50 percent of education spending, in-line with the target. Approximately 2,500 student-teachers have been enrolled in the teacher training program and are expected to complete their training in 2010. With respect to school visits by inspectors, the Ministry has doubled the number of inspectors and acquired dozens of motorcycles and other small vehicles to facilitate travel to and from schools. Full compliance was not achieved because capacity constraints and changes in leadership at the Ministry of Education slowed the reforms.

\section{(ii) Health and HIV/AIDS:}

a) Increase by at least 10 percentage points immunization rates for DPT3, BCG and measles.

b) Approval by the Government of National Policy, Strategic Plan and Scale up Operational Plan for HIV/AIDS prevention and treatment.
Substantially implemented. Immunization rates for DPT3 increased from 47 percent in 2005-06 to 68 percent in 2007 and for measles from 45 percent in 2005-06 to 54 percent in 2007. But for BCG the rate remained at around 70 percent in 2007 , compared to 73 percent in 2005-06.

Implemented. The National Policy Strategic Plan and Scale up Operational Plan for HIV/AIDS prevention and treatment was approved by the Prime Minister on January 15, 2007. The Plan for HIV/AIDS prevention and treatment is being implemented.

\section{Debt management}

(a) Centralization of all information on public external and domestic foreign currency debt in a single database;
Implemented. The SYGADE software for centralized database has been installed and quarterly reports have been produced, supported by technical assistance and training from UNCTAD. (b) Publication of two consecutive up-to-date quarterly reports on external debt data with a maximum 3 month-lag in the period immediately preceding the completion point.
Implemented. The report for end-December 2008 has been generated and is on the website www.mefhaiti.gouv.ht. The second report for end-March 2009 was published in June. 


\section{A. PRSP}

\section{The Poverty Reduction Strategy Paper or DSNCRP (Document de Stratégie} Nationale pour la Croissance et la Réduction de la Pauvreté) was approved by the Government and submitted to IDA and the IMF on November 30, 2007. The DSNCRP was prepared through a participatory process consisting of consultations with civil society, government officials, and development partners. The overall strategic priorities were structured around three pillars: (i) enhancing human development, with a focus on improving delivery of basic services; (ii) improving security and the justice system; and (iii) promoting vectors of growth through agriculture and rural development, tourism, and infrastructure. The DSNCRP also emphasized the importance of a stable macroeconomic framework and sound management of public resources.

6. The DSNCRP was discussed by the IDA and IMF Boards in February 2008. As noted in the Joint Staff Advisory Note (JSAN), the DSNCRP presents the government's long-term vision to foster growth, reduce poverty, and raise living standards. Staffs considered the three strategic pillars-human development, democratic governance, and vectors of growth - to be an appropriate focus in light of the challenges facing Haiti. Addressing these areas can both improve welfare in the short-term and provide the foundation for long-term economic growth. At the same time, staffs also recommended that the government continue its work on several elements of the strategy. Specifically, work is needed to identify a clear set of specific actions for each sector, develop a consistent set of indicators and targets, and ensure that an adequate monitoring and evaluation mechanism is in place. It will be important to link the DSNCRP three-year costing strategies into the annual budget process to ensure that sufficient resources can be garnered for its implementation.

7. Although the government has set up participatory and inclusive mechanisms to monitor implementation of the DSNCRP, the lack of available statistics hampers a proper assessment of progress in poverty reduction. As noted in the JSAN, the participatory monitoring structures include a wide range of stakeholders, and the qualitative instruments used are valuable. However, conducting a new household consumption survey will be essential to update poverty measures since the last survey was conducted in 2001 . The household survey would also provide baselines for several indicators to measure progress on the DSNCRP. Staffs recommend that the government ensure the survey is completed in a timely manner and its results used to target future policy actions under the DSNCRP.

\section{The first Annual Progress Report (APR) of the country's DSNCRP highlights} the progress and the challenges during the first year of PRSP implementation. Haiti was hit by a series of unexpected and devastating shocks since the DSNCRP document was approved in 2007. In April 2008, Haiti experienced riots over rising food and fuel prices which prompted the resignation of the Prime Minister and led to a five-month political stalemate that severely constrained government operations including the approval of key economic legislation and the FY 2009 budget. Subsequently, Haiti was also hit by four 
back-to-back hurricanes and tropical storms in August-September, which caused extensive food shortages with 60 percent of the Fall harvest destroyed. Distribution networks, transportation, and housing were destroyed and damage to infrastructure is estimated at about 15 percent of GDP. These events altered considerably the DSNCRP implementation and priorities.

\section{Despite the challenges and disruptions caused by the succession of shocks,} implementation of the PRSP has been satisfactory. The JSAN reviewing the first Progress Report has been prepared by the staffs of IDA and the IMF and is being presented along with this document to the Boards of IDA and the IMF. The APR highlights progress in the areas of macroeconomic stability, economic governance, and social sector policies. Overall, the staffs of the IDA and IMF have reviewed progress on each of the pillars of the DSNCRP and concluded that progress during the first year of implementation has been satisfactory.

\section{The IDA and IMF staffs conclude that the trigger on the preparation of a full} PRSP through a participatory process and satisfactory implementation for at least one year has been implemented.

\section{B. Macroeconomic Stability}

\section{Since reaching the decision point in November 2006, Haiti has maintained} macroeconomic stability. Despite difficult political conditions, continuing security challenges, and severe shocks including multiple natural disasters, the authorities have established a solid track record of economic performance, building upon the stabilization efforts begun in 2004 (see Text Table 1). Following successful completion of a Staff-Monitored Program and two annual programs supported by Emergency Post-Conflict Assistance leading up to the decision point, performance under the PRGF-supported program has remained satisfactory.

\section{Growth picked up somewhat and inflation declined steadily through FY 2007.}

After a period of flat or falling output prior to FY 2004, growth turned positive in FY 2005 and reached 3.4 percent in FY 2007. This delivered a much-needed improvement in real per capita income, which had been falling at an average rate of 2 percent a year over two decades. High oil and food prices, which contributed to riots and a political stalemate, as well as a series of devastating hurricanes, affected Haiti in 2008, but growth remained positive at just over 1 percent. In U.S. dollar terms, per capita income rose from about $\$ 500$ in FY 2005 to above $\$ 700$ in FY 2008. Growth is expected to pick up only gradually in the near term (to 2.0 percent in FY 2009 and 2.4 percent in FY 2010) given recent shocks that have weakened productive capacity in Haiti, and the impact of the global economic slowdown. 
Text Table 1. Haiti: Selected Macroeconomic Indicators, FY 2002-09

\begin{tabular}{|c|c|c|c|c|c|c|c|c|}
\hline & $2002-05$ & 2006-09 & 2004 & 2005 & 2006 & 2007 & 2008 & $\begin{array}{r}2009 \\
\text { proj. }\end{array}$ \\
\hline & \multicolumn{8}{|c|}{ (in percentage change, unless otherwise indicated) } \\
\hline \multicolumn{9}{|l|}{ Economic growth and prices } \\
\hline Real GDP & -0.4 & 2.2 & -3.5 & 1.8 & 2.3 & 3.4 & 1.2 & 2.0 \\
\hline Consumer prices (period average) & 20.3 & 10.7 & 28.3 & 16.8 & 14.2 & 9.0 & 14.4 & 5.1 \\
\hline Exchange rate (local currency per U.S. dollar, period average) & 36.6 & 39.5 & 39.7 & 39.0 & 41.4 & 37.4 & 38.3 & \\
\hline Gross investment (in percent of GDP) & 27.6 & 29.5 & 27.3 & 27.4 & 28.9 & 27.7 & 26.0 & 35.4 \\
\hline & \multicolumn{8}{|c|}{ (in percent of GDP) } \\
\hline \multicolumn{9}{|l|}{ External sector } \\
\hline Exports of Goods and services & 14.2 & 12.7 & 14.4 & 14.0 & 14.4 & 12.7 & 12.0 & 11.5 \\
\hline Imports of Goods and services & 42.5 & 41.0 & 43.7 & 42.9 & 44.2 & 37.8 & 41.4 & 40.7 \\
\hline External current account balance, including grants & -0.3 & -2.2 & -1.6 & 2.6 & -1.4 & -0.2 & -4.2 & -3.0 \\
\hline Net official external financing & 4.9 & 7.6 & 2.8 & 7.6 & 7.9 & 6.4 & 6.8 & 9.4 \\
\hline \multicolumn{9}{|l|}{ Government finance } \\
\hline Total revenue and grants & 10.6 & 15.1 & 10.2 & 13.1 & 13.2 & 15.1 & 14.3 & 17.0 \\
\hline Total expenditures & 13.0 & 17.5 & 11.4 & 15.7 & 14.9 & 14.9 & 17.1 & 21.7 \\
\hline Overall fiscal balance & -2.5 & -2.4 & -2.4 & -2.5 & -1.7 & 0.2 & -2.9 & -4.7 \\
\hline
\end{tabular}

Sources: Haitian authorities; and staff estimates and projections

\section{Improved fiscal management enabled Haiti to rely less on central bank financing} and contributed to lower inflation. Government revenue, which had fallen to 8.9 percent of GDP in FY 2004 reached 10 percent of GDP by FY 2006 and has been maintained near that level. Stronger policies were rewarded with greater external support, including an increase in grants from about 3 percent of GDP in FY 2006 to about 4 percent in FY 2008. This enabled Haiti to undertake much needed outlays without reliance on central bank financing, which had been substantial in earlier years, and to repay some outstanding central bank credit in FY 2006 and FY 2007. In turn, this helped bring inflation down from double-digit levels prior to the decision point to 7.9 percent by end-2007. The food and fuel price shocks pushed inflation up in 2008, but prices have fallen sharply in FY 2009 in line with the drop in commodity prices, and inflation is expected to be in the low single digits for the year despite some recourse to central bank financing in FY 2009 given exceptional needs following the Fall 2008 hurricanes.

14. Despite sharp increases in international commodity prices since decision point, Haiti has registered a significant improvement in its international reserve coverage. Haiti's current account deficit (including grants) widened substantially in FY 2008 to more than 4 percent of GDP, due in large part to food and fuel price shocks. Despite this development, international reserve coverage rose from 1.4 months of imports in FY 2005 to 3 months by FY 2008, supported by higher levels of official support and remittances.

\section{The IDA and IMF staffs conclude that the trigger on maintenance of macroeconomic stability and satisfactory implementation of the PRGF program has been implemented.}




\section{Public Expenditure Management and Governance}

\section{The government's program of economic governance reforms to increase} transparency and efficiency in the use of public resources and external assistance is being implemented successfully. The government has produced an action plan for public financial management reform, based on the Public Expenditure Management and Financial Accountability (PEMFAR) study produced with support from the World Bank and the IADB. Key areas of progress include budget preparation, execution, and control. The FY 2008 budget was submitted to Parliament before the start of the fiscal year. The delays in submitting the FY 2009 budget were due to the five-month political stalemate and the exogenous shocks experienced during the second half of FY 2008, which slowed the budget preparation process. The authorities are committed to presenting the FY 2010 budget to Parliament by end-June 2009, in line with the constitutional requirement. The coordination and consultation process between the Ministry of Economy and Finance, the spending ministries, and the Ministry of Planning and External Cooperation has improved during budget preparation.

\section{Budget execution has been strengthened through recent measures including:}

(i) strengthening of programming units of key spending ministries through deployment of trained experts in project formulation and implementation; (ii) deployment of 34 public accountants and budget controllers to key line ministries; (iii) extension of the integrated financial management system, SYSDEP, to line ministries; and (iv) improvement of knowledge of public procurement procedures by public accountants and budget controllers. It is worth noting that satisfactory execution of the FY 2008 budget has been realized by using regular budget processes. The use of discretionary current accounts by ministries has continued to decrease, with the share of public spending executed through the use of these current accounts during FY 2008 estimated at less than 3 percent of total non-salary current public expenditures. The budget execution reports are available on the MEF website: www.mefhaiti.gouv.ht. After the hurricanes, an emergency law authorized the execution of some spending outside the normal budget process (about 3 percent of GDP). The authorities are recording this spending using the normal budget classification and are publishing the relevant spending execution reports.

\section{Adoption of an automated mechanism to track public expenditures for poverty reduction}

\section{The integrated financial management system (SYSDEP) has been operational} since 2005 and was extended to all line ministries during FY 2008 and FY 2009 and it now tracks all current spending. The budget classification system, which has also been improved, allows for classification on administrative and economic bases, and is relatively close to international standards. This has facilitated the tracking of poverty reducing spending and the publication of quarterly reports on these expenditures since FY 2008. The government is committed to continue accelerating budget execution in line with the PRSP priorities. 
19. The IDA and IMF staffs conclude that this trigger has been implemented in view of the satisfactory mechanism put in place for tracking public expenditures.

\section{Alignment of public spending priorities with the PRSP}

20. The Government's budgets reflect the priorities as outlined in the PRSP. The share of poverty-reducing spending in the FY 2008 budget is estimated at 56 percent, up from 43 percent in FY 2007. With the exception of infrastructure which reflects posthurricane reconstruction needs, spending plans in the FY 2009 budget, the first to be prepared following approval of the DSNCRP, are broadly in line with the DSNCRP priorities. Budget allocations are close to one-third of the three-year DSNCRP spending envelope and for some sectors are well above this level.

21. The IDA and IMF staffs conclude that this trigger has been implemented given the good alignment between the budgets and public spending priorities, as outlined in the PRSP.

\section{Preparation of Government Accounts}

22. Budget control mechanisms have also been significantly strengthened. The draft budget review laws (Projet de Loi de Règlement) for FY 2006 and FY 2007 prepared by the Ministry of Economy and Finance (MEF) were reviewed by the Supreme Audit Institution (Cour Supérieure des Comptes et du Contentieux Administratif, CSCCA). The draft budget review laws accompanied by the CSCCA's legal opinions were transmitted by the MEF to the Parliament for adoption on January 10, 2009. The review of the draft Budget Review Laws is on the agenda of the Parliament. The FY 2004 and FY 2005 treasury accounts were audited by CSCCA and were published on the MEF website on April 20, 2009. The FY 2006 and FY 2007 treasury accounts were audited by CSCCA along with the review of budget review laws. They will be published after they have been reviewed by Parliament.

\section{In the view of IDA and IMF staffs, the trigger on preparation of government} accounts has been substantially met. Full compliance was not possible, primarily due to the political stalemate which slowed government's operations in FY 2008 and limited capacity to produce timely budget review laws. In view of the considerable progress, staffs recommend that a waiver be granted for non-observance of this trigger.

\section{Public Procurement}

24. Progress has been slower in implementing procurement reforms. The draft Procurement Law was passed by Haiti's Parliament in June 2009 and constitutes a solid legal basis for the establishment of a modern and transparent procurement system. Additional policy actions already taken to advance procurement reforms include the creation of the Commission National des Marchés Publics (CNMP), the 2005 decree to amend the existing procurement law, and the standardization of procurement procedures. 
25. The delay in meeting this condition was due to obstacles encountered in submitting the new draft Procurement Law to Parliament, including the five-month political stalemate in 2008. Despite the absence of a consistent legal framework for procurement, partial adoption of improved procedures by some key government entities has occurred. The CNMP submitted the draft procurement law to the Prime Minister's Office (PMO) in July 2007 for review and comments. Due to the limited number of legal staff at the PMO and the full legislative agenda that year, an in-depth review of the law only began in May 2008. The PMO's review and eventual submission of the law to Parliament was further delayed by the social, political and economic crises that intervened.

\section{Despite the delay in submitting the Procurement Law to Parliament, improved} procurement practices consistent with the draft law have been adopted by some government entities. This progress has been achieved largely through the efforts of the CNMP, which introduced standard bidding documents and a procedures manual to government procurement staff (including newly-appointed members of Commissions Ministérielles and Commissions Spécialisées) through a series of seminars delivered in 2006 and 2007. These standardized procedures and documents are consistent with the new Procurement Law and their distribution is expected to speed the adoption of improved procurement practices. Since its creation in early 2005, the CNMP has assumed a leadership role and improved public procurement practices through its review/approval of hundreds of procurement processes each year, as well as hands-on training of procurement staff in key purchasing entities. As a result, there is evidence that the percentage of noncompetitive procurement (value of contracts awarded without competition as percent of all contracts awarded) has declined from an estimated 85 percent in 2004 to 59 percent in 2006 . However, more significant changes in government procurement practices depend now on full implementation of the new legislation to consolidate the procurement reforms introduced in 2004. The CNMP estimates that it will take a further six months after the law becomes effective to broaden compliance with the standard documents and procedures in all the target agencies to a level which could be subjected to independent audit with the expectation of a positive result.

27. The authorities have reiterated their commitment to implementing the new procurement framework immediately. The implementing regulations are ready and satisfactory implementation of the new procurement framework by all government agencies has been incorporated in the common budget support conditionality matrix that is being agreed with Haiti's main donors.

28. The IDA and IMF staffs recommend that a waiver be granted, on the basis of progress to date and continued commitment of the CNMP to advance the procurement reforms in a difficult environment. 
Adoption of a law on asset declaration and submission of one annual compliance report on monitoring of asset declarations covering the preceding year

29. The Asset Declaration Law, Loi portant Déclaration de Patrimoine par certaines Catégories de Personnalités Politiques, de Fonctionnaires et autres Agents Publics, was prepared by the Anti Corruption Unit (Unité de Lutte contre la Corruption, ULCC), adopted by Parliament in 2007 and published in the Official Gazette, Le Moniteur, in February 2008. The Blank Disclosure form was released in June 2008 and is available on the ULCC website. As per its Article 20, the application of the law is performed "on a progressive basis" and became fully effective one year after its official publication in the Moniteur, on February 20, 2009. The compliance report for the first year has been submitted by the Unite de Lutte Contre la Corruption to the President of the CSCCA and the Parliament on April 24, 2009. So far 283 Government officials have submitted their asset declaration forms including all the ministers, most senators, and a few judges and deputies.

30. The staffs of IDA and the IMF conclude that the trigger on the asset declaration law has been implemented.

\section{Structural Reforms}

31. The government has taken important steps that will enable it to improve revenue collection. Revenue collection of around 10 percent of GDP inhibits Haiti's ability to undertake priority spending needed to address dire poverty. Since the decision point, Haiti has strengthened its customs and tax administration systems.

\section{A new computerized customs management system has been installed in the} major ports. Customs revenues comprise nearly a third of total revenue, and in addition, an important share of domestic taxes is also collected at customs posts. With support from the World Bank and UNCTAD, by end-April 2009 the authorities were using the ASYCUDA World tracking software, aimed at improving customs collections, at customs posts in Portau-Prince (air and sea ports), Cap Haïtien, and Saint Marc. Delays at other customs posts, including because of hurricane damage in Gonaives and Miragoane, have been addressed. As a result, ASYCUDA is now also functioning in the provincial posts of Belladere, Gonaives, Malpasse, Miragoane, and Ouanaminthe. In addition to the installation of ASYCUDA World, the customs process has been formalized, customs personnel capacity has been enhanced, and SGS is working in the provinces to help ensure effective customs collection. A sizeable fiveyear project to modernize and strengthen overall revenue administration has been launched with assistance from Canada.

33. The ability to track and collect tax revenue in key areas has been enhanced. New software has been installed and is operational for the central taxpayer file in Port-au-Prince, and this file has been linked so that it now includes taxpayer information for Cayes, CapHaïtien, Fort Liberté, Miragoane, Port de Paix, and Saint Marc. Jacmel, Gonaives, Hinche, and Jeremie are also linked to the central taxpayer file. The central file includes the taxpayer 
number and vehicle registration, driver's license, and registration card information. In addition, work is underway to import into the new system old database information for Petionville.

\section{The IDA and IMF staffs conclude that the structural reform triggers on strengthening of customs and tax administration have been implemented.}

\section{E. Social Sectors}

\section{Education}

35. A satisfactory mechanism transferring subsidies to schools has been established, and is currently supporting an estimated 80,000 children. Starting in school year 2007-08, the tuition waiver program transferred subsidies to 600 schools representing tuition waivers for nearly 30,000 students in grade one in Les Nippes and Artibonite. In school year 2008-09, these same schools continued in the program, with students in grade one having moved into grade two, and a new cohort of beneficiaries entering grade one. In addition, the program has also been extended to another 605 schools in six additional regional departments. Based on preliminary results as of mid-June 2009, the independent audit of schools receiving public transfers verified transfers for over 50,000 children.

\section{Due to shifting priorities related to the emergencies of 2008, the overall} education financing target was narrowly missed. Spending for 2006-07 increased to 19.4 percent, and budget allocations for 2007-2008 reached 20.3 percent, just shy of the 21 percent target. Basic education expenditures did account for 50 percent of education spending, in-line with the target. ${ }^{2}$ Unfortunately, capacity constraints and changes in leadership at the Ministry of Education slowed the policy reform process linked to teacher training. The Ministry has made significant progress with the design and launch of the program, including developing the curriculum, signing contracts with the public and private training providers, and testing and recruiting student-teachers. The program officially started in the Spring of 2009, with approximately 2,500 student-teachers enrolled, with an expected graduation date of Spring 2010. With respect to school visits by inspectors, the Ministry has doubled the number of inspectors and acquired dozens of motorcycles and other small vehicles to facilitate their travel to and from schools. Despite the recent creation of a database, however, it is difficult to ascertain whether the average of two visits per school has been met as the database is currently incomplete.

\footnotetext{
${ }^{2}$ As reported in République d'Haïti (2009), « Premier rapport annuel de mise-en-œuvre du DSNCRP (2007-2008) pour réussir le saut qualitatif », Port-au-Prince.
} 
37. In the opinion of IDA and IMF staffs, the trigger on education has been substantially implemented and staffs recommend that a waiver be granted based on the significant progress to date.

\section{Health}

\section{Immunization rates for DPT3 and measles increased but BCG immunization} rates have remained the same. Immunization rates for DPT3 have increased from 47 percent in 2005-06 to 68 percent in 2007, and measles increased from 45 to 54 percent over the same period. BCG immunization rates, however, remained at around 70 percent in 2007 (compared to 73 percent in 2005-06). The BCG vaccine is given to infants born in health facilities with trained health personnel. As the coverage of deliveries in health facilities has not increased, the current coverage is practically the same as the baseline and the target has not been met. The Canadian International Development Agency (CIDA) and the Pan American Health Organization are assisting the government to improve institutional deliveries through the program "Soins Obstetriques Gratuits" (SOG), which provides free obstetric care to women to deliver in health facilities. This program also aims to vaccinate every child born in SOG health services. The births in the 50 institutions covered by the SOG program cover about 60,000 newborns or about a third of the total newborns in the country. The SOG program started in 2008 and will run through 2011.

\section{In the opinion of IDA and IMF staffs, the trigger related to the increase in} immunization rates has been substantially implemented and staffs recommend that a waiver be granted based on the significant progress to date.

\section{Haiti is successfully implementing its strategic plan for HIV/AIDS prevention} and treatment, which was approved in January 2007. Haiti has the highest HIV/AIDS infection rate in the Western Hemisphere. Recent household surveys indicate that the spread of infection has slowed considerably, with declines in prevalence rates among several key demographic groups, such that Haiti is being cited as a successful case of providing treatment to HIV-positive people in a very low-income, fragile state. There are 120,000 people living with HIV/AIDS and 15,000 of them are estimated to be on anti-retroviral therapy. Approximately 7,500 people are estimated to have died of HIV in 2008. The Government prepared a national multi-sectoral HIV/AIDS plan for the period 2002-06 and 2008-12, addressing both prevention and treatment, and secured funding (US\$67 million) from the Global Fund for implementation. The National Policy Strategic Plan and Scale up Operational Plan for HIV/AIDS prevention and treatment was approved by the Prime Minister on January 15, 2007. This plan is being implemented in partnership with international organizations and civil service organizations, with an ambitious public awareness campaign. Partnerships such as UN joint action (organized by United Nations Children's Fund (UNICEF), World Health Organization (WHO) and United Nations Stabilization Mission in Haiti (MINUSTAH)) contributed to scaling up services for the prevention of mother to child transmission in 2008 . The number of sites offering anti- 
retroviral therapy (ART) services increased from 33 in 2006 to 46 in 2007 and the number of sites offering prevention of mother-to-child transmission services increased from 88 in 2006 to 92 in 2007. The United Nations General Assembly Special Session (UNGASS) 2007 reported that there were nearly twice the number of people on ART at the end of 2007 as there were at the end of 2006.

41. The IDA and IMF staffs conclude that the trigger related to the National Policy, Strategic Plan and Scale up Operational Plan for HIV/AIDS prevention and treatment has been met.

\section{F. Debt Management}

42. Haiti has taken steps to strengthen its debt management capacity. Although the central bank (BRH) has for some time produced detailed monthly reports on external debt service and debt stocks, the decision point document highlighted priorities for improvements in debt management. These include creating a single database for external and domestic debt that both the MEF and BRH can access.

\section{All public external and domestic debt data have been centralized in a single} database. As detailed in Appendix I, with support from UNCTAD Haiti has installed the most recent version of the Debt Management Financial and Analysis System (DMFAS) debt management system, which will enhance the availability, quality, and security of debt data. Both the MEF and BRH have access to the database and the staffs of both institutions have received extensive training from UNCTAD in the use of the updated software. The completeness and accuracy of the new database through end-September 2008 was also verified as part of the completion point debt data reconciliation, with only minor errors that the authorities are in the process of rectifying. With the new database, some functions related to debt recording, reporting, and analysis can be transferred from the BRH to the MEF, which, over time and with additional training, would help the MEF improve overall debt management and develop external borrowing strategies, negotiate external loan agreements with creditors, and analyze costs and risks associated with new borrowing.

44. The authorities have begun to produce quarterly external debt reports using the new database. The first quarterly external report covering the quarter ending in December 2008 was published in April 2009. The second quarterly report covering the quarter ending in March 2009 was published in June 2009, at which time an amended December 2008 report was also published to reflect steps the authorities have taken to address minor errors in the database identified in the validation process. The authorities will continue to publish quarterly reports and are also in the process of preparing a more detailed statistical bulletin on external debt.

45. The IDA and IMF staffs conclude that the trigger on debt management has been fully implemented. 


\section{Debt Sustainability After HIPC and MDRI Assistance}

\section{A. Updated Data Reconciliation and Revision of Assistance}

46. The debt stock at end-September 2005 has been revised upward relative to the decision point estimate. Staffs of IDA and the IMF, together with the Haitian authorities, have reviewed the debt stock at end-September 2005 against creditor statements. The nominal debt stock at end-September 2005 has increased from US\$1,336.3 million to US\$1,337.2 million, while the NPV of debt after delivery of traditional debt relief has increased by US\$0.5 million to US\$928.8 million (Table 1 and Figure 1). The revisions arose primarily from data discrepancies discovered during the debt reconciliation process.

47. Multilateral creditors. There were no significant revisions to the decision point database for multilateral creditors.

48. Paris Club creditors. The NPV of debt of two Paris Club creditors has been revised slightly to reflect more accurate data as of the completion point. The NPV of debt after traditional relief has gone up by US\$0.1 million and US\$0.2 million for Spain and Italy, respectively.

49. Other bilateral creditors. The NPV of debt for Taiwan, Province of China went up by US\$0.2 million based on more accurate data. Since the debt from Taiwan, Province of China is all post cut-off, no traditional debt relief is being provided. ${ }^{3}$

50. The three-year average of exports of goods and services used to evaluate HIPC assistance at the decision point has been revised upwards from an average of US\$525.3 million to US\$531.1 million at completion point. ${ }^{4}$

51. The original HIPC assistance calculated at decision point will not be revised at completion point. The upward revisions made to the NPV of debt and to the three-year average of exports of goods and services have resulted in a downward revision of the HIPC assistance calculated in NPV terms at the decision point from US\$140 million to US\$132 million (Table 2). Even though the amount of HIPC relief can be revised in response to new information according to existing policy rules, ${ }^{5}$ the difference as estimated by the staffs is equivalent to the minimum indicative threshold of about 1 percent of the targeted NPV of debt after enhanced HIPC relief (Tables 2 and 3). ${ }^{6}$ Thus, the staffs do not

\footnotetext{
${ }^{3}$ Haiti's cut-off date for Paris Club creditors is October 1, 1993.

${ }^{4}$ The revision of export data reflects updated estimates from the authorities.

5 "Information Reporting in the Context of HIPC Initiative Assistance", approved by the members of the Executive Boards of the IMF and IDA (IDA/SecM2002-0131), March 4, 2002.

${ }^{6}$ The targeted NPV of debt is that needed to bring the NPV of debt-to-exports ratio to 150 percent after traditional and HIPC debt relief.
} 
recommend a downward revision of assistance under the Enhanced HIPC Initiative at the completion point.

\section{B. Status of Creditor Participation in the Enhanced HIPC Initiative}

\section{Haiti has received financing assurances of participation in the enhanced HIPC Initiative from creditors representing 96 percent of the NPV of HIPC assistance estimated at the decision point. Multilateral and Paris Club creditors have confirmed their participation in the HIPC Initiative and the staffs have encouraged the authorities to work toward reaching agreements with remaining creditors (Table 4).}

\section{Multilateral Creditors}

\section{The total amount of HIPC assistance committed by Haiti's five multilateral} creditors is US\$120.0 million in NPV terms, or 85.5 percent of total HIPC assistance (Table 4). IDA, the IMF, and the IADB Group also provided interim assistance amounting to US\$31.3 million in nominal terms through end-September 2008. The OPEC Fund for International Development (OFID) will provide debt relief by restructuring the terms of new loans disbursed after the completion point cutoff date of end-September 2008. ${ }^{7}$ IFAD will provide debt relief only at completion point.

\section{- Debt relief from IDA amounts to US\$52.8 million in NPV terms, as determined at} the decision point, which included a concessional rescheduling of arrears that took place in 2005 equal to US\$33.1 million in NPV terms, leaving US\$19.7 million to be delivered (Table 11). Of this amount, IDA has already delivered US $\$ 10.1$ million in nominal terms (US\$9.9 million in NPV terms) via a 50 percent reduction of debt service falling due during the interim period up. In January 2008, IDA suspended the delivery of interim relief, in line with IDA guidelines limiting the delivery of relief to no more than 50 percent of the approved amount prior to reaching the completion point. ${ }^{8}$ Upon reaching the completion point, IDA would provide the remaining portion of its assistance, amounting to US\$9.9 million in NPV terms, through a 51.6 percent reduction of debt service on eligible debt through July 2010.

\footnotetext{
${ }^{7}$ In anticipation of the completion point, OFID recently concluded an agreement with the Government of Haiti to provide full HIPC relief in the form of a concessional rescheduling of two outstanding loans, which should take effect slightly before the completion point is discussed by the Boards of the IMF and IDA.

${ }^{8}$ Almost 63 percent of the total amount of IDA HIPC relief (in NPV terms) took the form of a concessional rescheduling of arrears at the decision point. Table 16 notes that the percentage of assistance delivered during the interim period (in NPV terms) amounted to 19 percent of total HIPC relief, although it is equal to 50 percent of relief excluding the initial arrears clearance. For IDA's interim delivery assumptions, see: "Haiti-HIPC Debt Initiative: Revised Schedule of IDA's HIPC Debt Relief', IDA/R2007-0226.
} 
- Total IMF assistance under the enhanced HIPC Initiative is estimated at US\$3.1 million in NPV terms, or about US\$4.0 million in nominal terms. At the decision point, the IMF committed HIPC Initiative assistance of SDR 2.10 million (US\$3.12 million) in NPV terms. The IMF has already provided about SDR 0.3 million (US\$0.45 million) in nominal terms in the form of interim assistance. Should Haiti reach the completion point as scheduled in June 2009, the IMF will provide the remaining amount of its share of HIPC assistance through a stock-of-debt operation estimated at an additional SDR 2 million (US\$3 million) in nominal terms (Table 10).

- The IADB committed to provide US\$60.4 million in NPV terms in assistance at the decision point, including US\$9.7 million through a concessional rescheduling of arrears in 2003. Of the remaining US $\$ 50.7$ million in NPV terms, about US\$27.3 million of relief was provided during the interim period through a reduction in debt service, leaving US\$23.5 million in NPV terms to be delivered after the completion point.

- Other multilateral creditors. The modalities of assistance by all other multilateral creditors - the OFID and IFAD_-are summarized in Table 4.

\section{Paris Club Creditors have agreed in principle to provide their share of} assistance under the enhanced HIPC Initiative-about US\$15 million in end-September 2005 NPV terms (Table 4). Interim assistance has been provided through a flow treatment under Cologne terms, agreed on December 12, 2006. Haiti has signed bilateral agreements with all Paris Club creditors since reaching the decision point. Hence, all arrears which existed at the decision point have been cleared. Paris Club creditors are expected to deliver their share of HIPC Initiative assistance through a stock-of-debt reduction under Cologne terms, which should lead to the cancellation of all outstanding obligations of Haiti toward Paris Club creditors. Haiti has a single Official Development Assistance loan administered by IDA and funded by the Netherlands, Denmark, United Kingdom, Ireland, Belgium, Luxembourg, Germany, France, and Italy. Ireland and Luxembourg opted to cancel claims on all HIPC countries, regardless of their HIPC completion point status. The remaining creditor countries that are a part of this EU-IDA loan have rescheduled their credits with the provision that these will be cancelled on reaching completion point (Table 12).

\section{Non-Paris Club creditors are assumed to provide HIPC relief in terms} comparable to that of Paris Club creditors. The NPV of debt as of end-September to the non-Paris Club creditors is US\$37 million (4 percent of the total debt stock).

\section{Debt Outlook after HIPC Assistance and Consideration for Exceptional} Topping-Up of HIPC Assistance

\section{Haiti's nominal stock of external debt reached US\$1,884.4 million at} end-September 2008 (Table 5), compared with US\$1,337.2 million at end-September 
2005 (Table 1). At end-September 2008, in NPV terms, multilateral creditors accounted for 75 percent of total debt and bilateral creditors accounted for 25 percent. ${ }^{9}$ IDA, the IADB Group, the IMF, and the República Bolivariana de Venezuela are Haiti's largest creditors, accounting for 24 percent, 43 percent, 6 percent, and 8 percent, respectively, of total outstanding debt.

\section{The NPV of Haiti's external debt at end-September 2008, after full delivery of} the assistance committed under the HIPC Initiative at the decision point, is estimated at US\$1,199.7 million, equivalent to $\mathbf{1 5 5 . 8}$ percent of exports. Of this amount, US\$948 million is owed to multilateral creditors, US\$69 million to Paris Club creditors, and US\$183 million to other bilateral creditors (Table 5).

\section{Haiti's NPV of debt-to-exports ratio after full delivery of HIPC assistance at end-September 2008 is $\mathbf{2 5 . 3}$ percentage points higher than projected at the decision} point. At the decision point, the NPV of debt-to-exports ratio after full delivery of HIPC debt relief at end-September 2008 was projected to be 130.4 percent compared to the actual ratio of 155.8 percent (Text Table 2).

\section{Additional topping-up assistance can be provided under the HIPC initiative if} debt ratios have deteriorated relative to completion point projections, but Haiti does not qualify given its debt level after additional bilateral relief. ${ }^{10}$ Assuming full and unconditional delivery of enhanced HIPC assistance and additional debt relief provided by bilateral creditors, the NPV of the debt-to-exports ratio drops to 146.8 percent, below the HIPC threshold of 150 percent. Under the baseline scenario and assuming conditional delivery of HIPC relief and including the projected new borrowings, the NPV of debt-toexports ratio drops below the HIPC threshold in the medium term (after FY 2015) and continues to drop over the projection period. As described below, the provision of MDRI relief after Enhanced HIPC and additional bilateral relief brings Haiti's debt ratios well below the HIPC NPV debt-to-exports threshold. The following paragraphs provide a breakdown of the factors that have led to a higher NPV of debt-to-exports ratio after full delivery of HIPC assistance at end-September 2008 but before additional bilateral debt relief.

\footnotetext{
${ }^{9}$ This corresponds to a full reconciliation of multilateral debt data and bilateral debt data at end-September 2008. Haiti does not have any commercial external debt.

${ }^{10}$ The Enhanced HIPC Initiative framework allows for the provision, on an exceptional basis, of additional debt relief (or "topping-up") at the completion point. Additional debt relief is provided if a country's actual debt burden indicators have deteriorated compared to the decision point projection, and this deterioration is primarily attributable to a fundamental change in a country's economic circumstances due to exogenous factors (The Enhanced HIPC Initiative - Completion Point Considerations, and IDA/SecM2001-0539/1 (8/21/2001)). Additional debt relief may be provided to bring a country's debt ratio to the relevant HIPC threshold at the completion point. To date, six countries have received topping-up assistance under the enhanced HIPC Initiative: Burkina Faso, Ethiopia, Rwanda, Malawi, Niger and Sao Tome and Principe.
} 
60. The largest contributing factor to the deterioration in the NPV of debt-toexports ratio after full delivery of HIPC assistance was the higher-than-expected new borrowing, which pushed the ratio up by 23 percentage points. The increase in the NPV of the debt-to-exports ratio was due to a combined effect of higher new borrowing compared to the decision point baseline, the unanticipated change in export volumes, as well as changes in parameters and other factors (e.g., timing of the completion point). The debt stock increased due to new borrowing from Taiwan, Province of China and the República Bolivariana de Venezuela, in the amounts of US\$50 million and US\$167 million, respectively. ${ }^{11}$ As of September 30, 2008 the debt outstanding to non-Paris Club creditors was approximately US\$259 million, or 57 percent of Haiti's total bilateral debt, compared to 27 percent at end-September 2005. The new disbursements from Taiwan, Province of China were used for standard development financing. The financing from PetroCaribe is linked to oil imports from the República Bolivariana de Venezuela, with the amount of financing dependent on the cost of oil imports. This borrowing was used to finance emergency reconstruction projects following the devastating Fall 2008 hurricanes. Disbursements from multilateral institutions were largely in line with decision point projections.

61. Stronger than anticipated export performance contributed to bringing the ratio down by 13.2 percentage points. Exports turned out stronger than projected at the decision point, due largely to an increase in services receipts related to tourism. Following a hotel survey by the government in November 2006, estimates for daily average tourism expenditure have risen from US\$104 to US\$170.

\section{Unanticipated changes in the exchange and discount rates accounted for an} increase in the NPV of debt-to-exports ratio of 10.1 percentage points. Discount rates contributed 4 percentage points (U.S. dollar discount rates dropped, affecting the ratio, given that a major portion of Haiti's debt is in U.S. dollars), and the unanticipated appreciation of the dollar against most major currencies further contributed by 7 percentage points to the ratio. Changes in these parameters are determined by international markets and, thus, are considered exogenous to the country's economic circumstances.

63. The remaining increase of $\mathbf{5 . 5}$ percentage points is due to revisions in the decision point debt database, as well as changes in the timing and mechanisms used to deliver assistance during the interim period, as compared to the assumptions made at the decision point.

\footnotetext{
${ }^{11}$ The grant element of lending from Taiwan, Province of China and the República Bolivariana de Venezuela is lower than that of lending from multilateral institutions, which are Haiti's largest creditors.
} 
Text Table 2. Haiti: Breakdown of the increase in NPV of Debt-to-Export Ratio (As of end September-2008 1/)

\begin{tabular}{lrc}
\hline & $\begin{array}{c}\text { Percentage } \\
\text { Points }\end{array}$ & $\begin{array}{c}\text { Percent of Total } \\
\text { Increase }\end{array}$ \\
\hline NPV of debt-to-export ratio (as projected at Decision Point) & 130.4 \\
NPV of debt-to-export ratio (actual) & 155.8 \\
& & 25.3 \\
Unanticipated change in the ratio & 10.1 & $100 \%$ \\
1. Due to changes in the parameters & 3.6 & $40 \%$ \\
o/w due to changes in the discount rates & 6.5 & $14 \%$ \\
o/w due to changes in the exchange rates & 23.0 & $26 \%$ \\
2. Due to unanticipated new borrowing & 13.8 & $91 \%$ \\
o/w due to higher than expected disbursements & 9.2 & $55 \%$ \\
o/w due to lower concessionality of the loans & -13.2 & $36 \%$ \\
3. Due to unanticipated changes in export & 5.5 & $-52 \%$ \\
4. Due to changes in HIPC relief and other factors $2 /$ & & $22 \%$ \\
Bilateral debt relief beyond HIPC & -8.9 \\
NPV of debt-to-export ratio after full delivery of HIPC assistance and & 146.8 & \\
bilateral debt relief beyond HIPC (actual) & & \\
\hline
\end{tabular}

Source: Staff estimates.

1/ NPV of debt-to-export ratio after full delivery of enhanced HIPC assistance.

$2 /$ Including revisions to the end September-2005 database and changes in the timing and mechanisms of delivery of assistance compared to the assumptions in the decision point projections.

\section{Creditor Participation in the Multilateral Debt Relief Initiative}

\section{Contingent upon approval of the completion point under the enhanced HIPC} Initiative, Haiti would qualify for additional debt relief under the MDRI from IDA, the IMF, and the IADB. MDRI debt relief (net of HIPC assistance) would imply a stock of debt reduction of US\$841.0 million in nominal terms and would save Haiti US\$972.7 million in debt service through 2037 for IDA and 2044 for the IADB Group.

65. IDA. IDA would provide debt service relief under the MDRI amounting to approximately US $\$ 486.7$ million in nominal terms (Table 11 ). IDA would provide MDRI debt forgiveness by irrevocably canceling Haiti's payment obligations for credits disbursed before end-2003 and still outstanding on July 1, 2009. MDRI debt relief from IDA would imply average debt service savings (net of HIPC assistance) of US $\$ 16.8$ million per year through 2037. Upon reaching the completion point, MDRI assistance would reduce Haiti's debt stock to IDA by US $\$ 446.5$ million in addition to the debt relief received under the HIPC Initiative.

66. IMF. While the IMF is a participant in the MDRI, Haiti repaid all MDRI-eligible debt to the Fund prior to the completion point, when a new PRGF arrangement activated in 
November 2006 was used to repay all loans outstanding at end-December 2004, the cutoff date for MDRI eligibility. Thus, the IMF would only provide HIPC assistance at completion point.

67. IADB. Under the "IADB-2007" initiative, the IADB's Board of Governors has agreed to provide debt relief to Haiti over and above the HIPC Initiative, which would extinguish all debt to the IADB accumulated prior to end-2004 that remains outstanding at the completion point. This additional relief would amount to a reduction in debt service of more than US\$486 million in nominal terms, or a further reduction in Haiti's debt stock of over US\$395 million. ${ }^{12}$

\section{E. Debt Sustainability Outlook, 2009-28}

68. The baseline macroeconomic framework for the long-term debt sustainability analysis has been revised to take into account recent developments. Key macroeconomic assumptions for the completion point DSA using the HIPC methodology are summarized in Box 2 and in Text Table 3. Long-term assumptions are largely similar to those used in the decision point debt sustainability analysis. GDP growth in the out-years is still assumed to be 4.5 percent, but near- and medium-term growth is now assumed to be weaker, given actual outturns and recent shocks such as last year's hurricanes and the global financial crisis, which is affecting exports and contributing to a leveling off of remittances flows. Revenue is now assumed to rise over the projection period to about 15 percent of GDP compared with 16 percent assumed at decision point. The current account deficit excluding grants is still assumed to fall over the projection period, but by a smaller amount than assumed at decision point.

\section{Full delivery of debt relief under the HIPC Initiative and the MDRI would} significantly reduce Haiti's public external debt. In NPV terms, the stock of debt would be reduced from US\$1,320 million at end September-2008 to US\$641 million at end-September 2009 after enhanced HIPC relief, additional bilateral relief, and the MDRI (Table 6). The stock of external debt that will remain is primarily due to outstanding debt owed to multilateral creditors that do not participate in MDRI and non-Paris Club bilateral creditors, much of which has been contracted since the decision point. Nominal debt service relief would amount to US\$1,237.5 million as of FY 2009, of which MDRI relief would contribute US\$972.7 million (Table 7 shows annual savings).

70. The debt sustainability analysis shows that Haiti's NPV of debt-to-exports ratio will fall beneath the debt-burden threshold after Enhanced HIPC assistance, additional bilateral assistance, and MDRI debt relief (Table 8 and Figure 2). After Enhanced HIPC relief, additional bilateral relief, and MDRI relief, the NPV of debt-to-exports ratio drops to

\footnotetext{
${ }^{12}$ Based on IADB and World Bank estimates.
} 
79 percent in FY 2009, which is well below the HIPC threshold. The ratio increases in the medium term, reflecting higher external borrowing needs due to the impact of the global downturn on revenue and repayment of debt to the central bank, as well as somewhat less concessional recent borrowing from PetroCaribe. The NPV of debt-to-exports then declines over the long term, and does not breach the HIPC threshold again over the projection period.

\section{MDRI relief also significantly reduces the NPV of debt-to-GDP and debt-to-} revenue ratios. After both Enhanced HIPC and MDRI relief, the NPV of the debt-to-GDP ratio falls to 9 percent at end-September 2009, and is expected to remain at an average of 13 percent over the projection period. Finally, the NPV of debt-to-revenue ratio would be reduced from 188 percent in FY 2008 to 90 percent in FY 2009, and after increasing to 109 percent in FY 2013, falls steadily to 96 percent in FY 2028.

\section{Haiti will also benefit from a reduced debt service burden. Following Enhanced} HIPC, additional bilateral, and MDRI debt relief, Haiti's average debt service-to-exports and debt service-to-revenue ratios would be cut in half for the FY $2009-2008$ period ( 5 percent for each measure, compared to 10 percent following traditional relief only). Over the longer term (FY 2019 - 2028), Haiti's average debt service savings would be about 2 percentage points relative to both exports and revenue ( 5 percent versus 7 percent).

\section{Box 2. Macroeconomic Assumptions}

Growth and inflation: After somewhat lower growth in the near term given recent shocks - real growth of 2.0 percent in FY 2009 and 2.4 percent in FY 2010 - real GDP growth would rise gradually and reach the assumed long-term growth rate of 4.5 percent by 2017. After higher-than-projected inflation in recent years due to price shocks, inflation would reach 5 percent by FY 2011.

Fiscal policy: Revenue, which had been projected to be about 11 percent of GDP by FY 2009 has been affected by the global slowdown, particularly through lower import taxes due to the fall in commodity prices, and is expected to be about 10 percent of GDP in FY 2009. Revenue is expected to grow gradually to about 15 percent of GDP by the end of the period. With primary spending projected near 20 percent of GDP, the fiscal deficit would fall over time to reach about 2.3 percent of GDP by the end of the period and would average 2.6 percent of GDP compared to the 2.0 percent of GDP average assumed at decision point.

Grants and financing: After a near-term increase in grants, reflecting hurricane reconstruction needs and additional pledges of support from the recent donors conference, a conservative approach is taken with the U.S. dollar value of grants only assumed to grow by 2 percent annually in the long-term. It is assumed that Haiti remains eligible for concessional assistance from IDA and the IADB that would cover 80 percent of Haiti's external borrowing needs. The assumed grant element of new external borrowing is 47 percent, as shown in Figure A1 of Appendix I.

Current account: After falling by about 3 percent in FY 2009 due to the global downturn, exports of goods and services in U.S. dollar terms are expected to rebound by 7 percent in FY 2010 (reaching just under 12 percent of GDP) and then rise to a level of about 16 percent of GDP by the end of the projection period. The current account deficit excluding grants would fall to about 6 percent of GDP, a somewhat larger deficit than projected at decision point due to higher imports. 
Text Table 3. Haiti: Long-Term Macroeconomic Assumptions, FY 2009-29

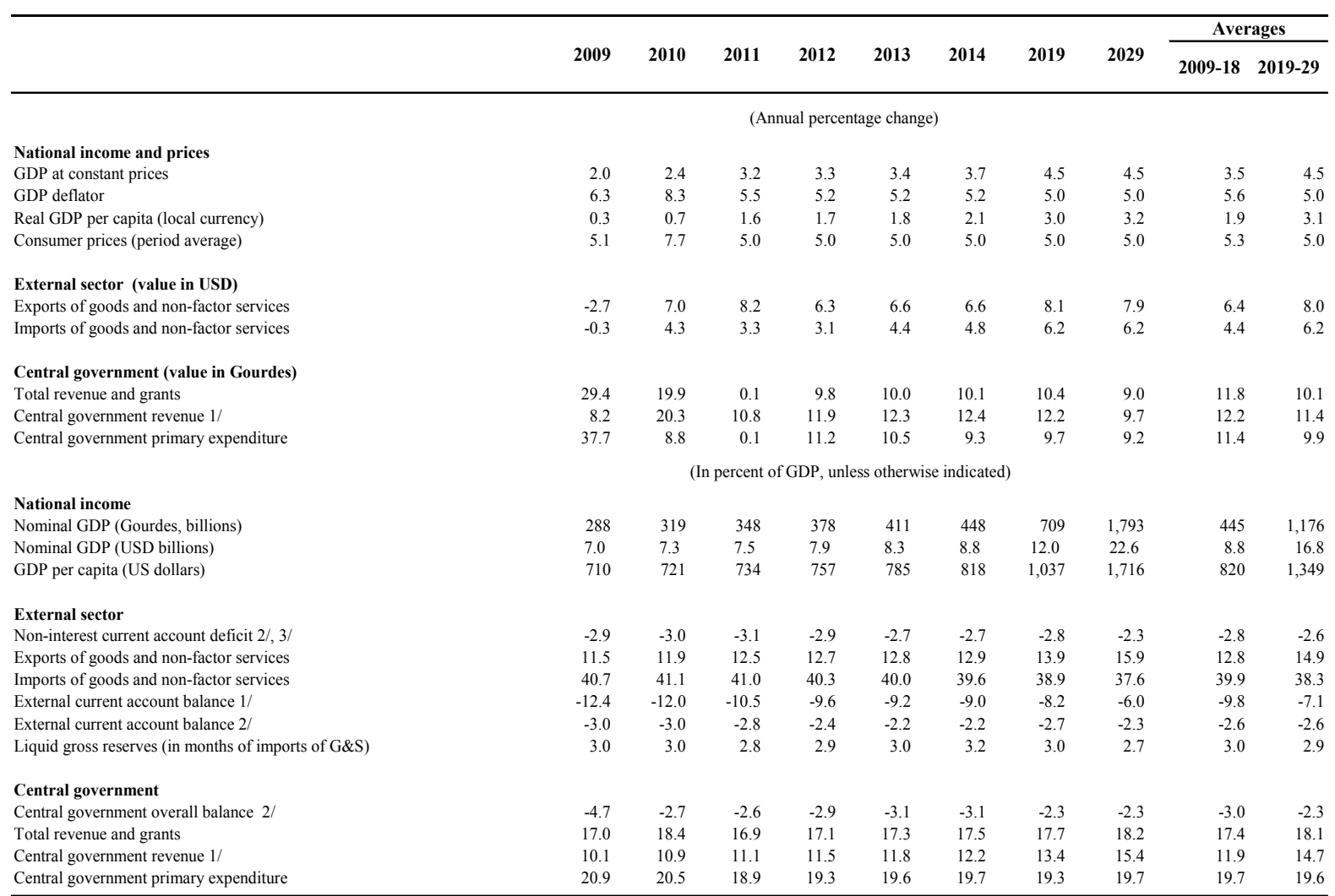

$1 /$ Excluding grants

2/ Including grants

3/ Includes interest earned on foreign exchange reserves.

\section{F. Sensitivity Analysis and Long-Term Debt Sustainability}

73. The sensitivity analysis for Haiti consists of three scenarios to test the sustainability of Haiti's external debt, after assuming full delivery of enhanced HIPC assistance, additional bilateral assistance, and debt relief under the MDRI. These scenarios replicate those used at decision point to facilitate an assessment of how Haiti's debt has evolved (Table 9 and Figure 3). The scenarios help capture key risks to Haiti, including those stemming from its vulnerability to natural disasters, which can create urgent borrowing needs (Scenario 1) and adversely affect exports, growth, and revenue (Scenarios 2 and 3).

\section{Scenario 1: Less concessional borrowing}

74. In this scenario, interest rates are assumed to be $\mathbf{1 0 0}$ basis points higher than in the baseline scenario. ${ }^{13}$ This first scenario demonstrates the importance of borrowing on

\footnotetext{
${ }^{13}$ The baseline assumptions are described in Box 2 and Text Table 3.
} 
highly concessional terms to keep ratios below the HIPC threshold. It considers the sensitivity of the projections to less favorable concessionality on new borrowing. Under this scenario, Haiti's NPV of debt-to-exports ratio slowly deteriorates. Compared to the baseline scenario, it is higher by 27 percentage points by FY 2028, leaving the ratio at about 129 percent in FY 2028.

\section{Scenario 2: Lower export growth}

\section{In this scenario, exports are assumed to grow at 4.6 percent, an average} reduction of 2.5 percentage points compared to the baseline scenario. ${ }^{14}$ The second scenario considers the sensitivity of the projections to lower export growth. Lower export growth is assumed to reduce government revenues, through lower GDP, and to increase the need for new financing. Based on these assumptions, the NPV of debt-to-exports steadily increases over the medium and long term, crossing the HIPC threshold in FY 2019 to reach 206 percent in FY 2028. This represents a deterioration of approximately 104 percentage points relative to the baseline scenario by FY 2028.

\section{Scenario 3: Lower GDP growth}

\section{In this scenario, GDP growth is assumed to be 2 percentage points lower on} average than in the baseline scenario. The third scenario considers the sensitivity of the projections to lower GDP growth as a result of slower implementation of structural reforms or governance concerns. Inability to maintain and enhance security, improve social and economic infrastructure, and implement structural reforms would weaken private sector confidence and investment. The resulting lower GDP growth would translate into lower government revenues and the need for increased new borrowing. Under this scenario, the NPV of debt-to-exports rises faster than the second scenario and breaches the HIPC threshold in FY 2018, reaching 255 percent in FY 2028. Compared to the baseline scenario, this represents an increase in Haiti's NPV of debt-to-exports ratio by 153 percentage points relative to the baseline scenario by FY 2028.

\section{The sensitivity analysis highlights the need for prudent debt management and} further reforms to avoid rising debt ratios following the completion point. While HIPC and MDRI relief will substantially reduce Haiti's debt burden, the sensitivity analysis shows that Haiti remains vulnerable, particularly if GDP or export growth is lower than assumed. In order to maintain debt ratios below the HIPC threshold post-completion point, it will be important to maximize grant assistance and borrow only on highly concessional terms, and undertake further reforms to achieve higher output and export growth given a relatively weak

\footnotetext{
${ }^{14}$ The reduction of 2.5 percentage points in export growth corresponds to the one standard deviation shock used in the decision point sensitivity analysis.
} 
export base. In this regard, maintaining security and ensuring that public investment and other reforms help improve transportation infrastructure, power reliability, port efficiency, resilience to natural disasters, and human capital would help catalyze needed investment, including in export industries.

\section{CONCLUSIONS}

78. In the view of IDA and IMF staffs, Haiti has met the requirements established in November 2006 for reaching the completion point under the Enhanced HIPC Initiative.

\section{In the opinion of IDA and IMF staffs, Haiti has made satisfactory progress in} implementing the reforms specified for reaching the completion point. It has implemented 11 out of 15 triggers and made good progress in implementing the other fourthe triggers on publication of audited government accounts; passage and implementation of a new procurement law in line with international best practice; increasing education funding to at least 21 percent of recurrent spending with a majority of education spending devoted to primary schooling, training 2,500 new primary teachers, and ensuring an average of two visits per year of primary schools; and increasing vaccination rates for DPT3, BCG, and measles.

- $\quad$ On submission and publication of audited government accounts, audited accounts have been submitted to Parliament. They will be published after being reviewed by Parliament.

- $\quad$ On public procurement, the Procurement Law was passed by Parliament in June 2009. In addition, a number of steps had already been taken to strengthen procurement procedures. Following the 2005 decree to amend the previous procurement law, the Commission Nationale des Marchés Publics (CNMP) was created, standard bidding documents and manuals have already been introduced to government procurement staff through a series of seminars in 2006 and 2007, and procurement procedures have been standardized.

- $\quad$ On education, the spending level was only narrowly missed and reflected the need to respond to emergencies in 2008, but primary schooling did account for 50 percent of education spending. A curriculum for teacher training has been developed, contracts with trainers have been signed, and approximately 2,500 student-teachers have now been enrolled and are expected to graduate in the spring 2010. The number of school inspectors has been doubled and other steps have been taken to facilitate inspections, but data weaknesses preclude determining whether an average of two visits per school has been achieved.

- On health, the BCG immunization rate did not increase over this period. This is largely linked to the fact that births in health facilities did not increase significantly. 
80. Small changes to debt and export data do not warrant a revision in the amount of HIPC debt relief. There have been minor upward revisions to the decision point debt stock and the goods and services export figures used to calculate HIPC assistance at decision point. These changes would imply a downward revision in HIPC relief, but since the implied reduction is equal to the threshold for such adjustments ( 1 percent change in the targeted NPV of debt following HIPC relief), no change in the amount of HIPC relief is proposed and the amount of relief to be provided will remain $\$ 140.3$ million in NPV terms. Haiti has received financing assurances of participation in the enhanced HIPC Initiative from creditors representing 96 percent of the NPV of HIPC assistance estimated at the decision point.

\section{Staffs are of the view that Haiti does not meet the requirements for exceptional} topping-up under the Enhanced HIPC Initiative. Although the NPV of Haiti's debt-toexports ratio after unconditional HIPC relief and additional bilateral relief is worse than anticipated at decision point, it is still under the HIPC threshold as of end-September 2008 and would remain below the threshold in the medium-term (after FY 2015).

\section{Haiti's debt burden will decrease significantly after it receives Enhanced HIPC} assistance and MDRI relief. After HIPC and MDRI assistance, the NPV of debt-to-exports ratio in FY 2009 is expected to decline from 169 percent (taking only traditional relief into account) to 79 percent. The NPV of debt-to-exports ratio would rise to 111 percent in FY 2014 before declining in subsequent years. While Haiti's debt ratios would be much more manageable after HIPC and MDRI relief, debt risks in Haiti remain high, as demonstrated in the HIPC sensitivity analysis, and also discussed in Appendix II.

83. In light of the discussion above, the staffs recommend that the Executive Directors determine that Haiti has reached the completion point under the Enhanced HIPC Initiative.

\section{ISSUES FOR DISCUSSION}

84. Executive Directors may wish to consider the following questions:

- Completion point: Do Directors agree that Haiti has reached the completion point under the Enhanced HIPC Initiative?

- HIPC assistance: Do Directors agree with staffs' recommendation that the same amount of HIPC assistance as called for at decision point (US\$140.3 million NPV terms) be provided to Haiti? 
- HIPC Debt Relief from the IMF: Do IMF Directors agree that the remaining IMF HIPC assistance of about SDR 2 million would be delivered on a stock basis to Haiti's Umbrella Account?

- Creditor Participation: Do Directors agree that Haiti's creditors have given sufficient assurances to irrevocably commit HIPC Initiative assistance to Haiti? 
Figure 1. Haiti: External Debt Stock Composition by Creditor Group

\section{End September-2005}

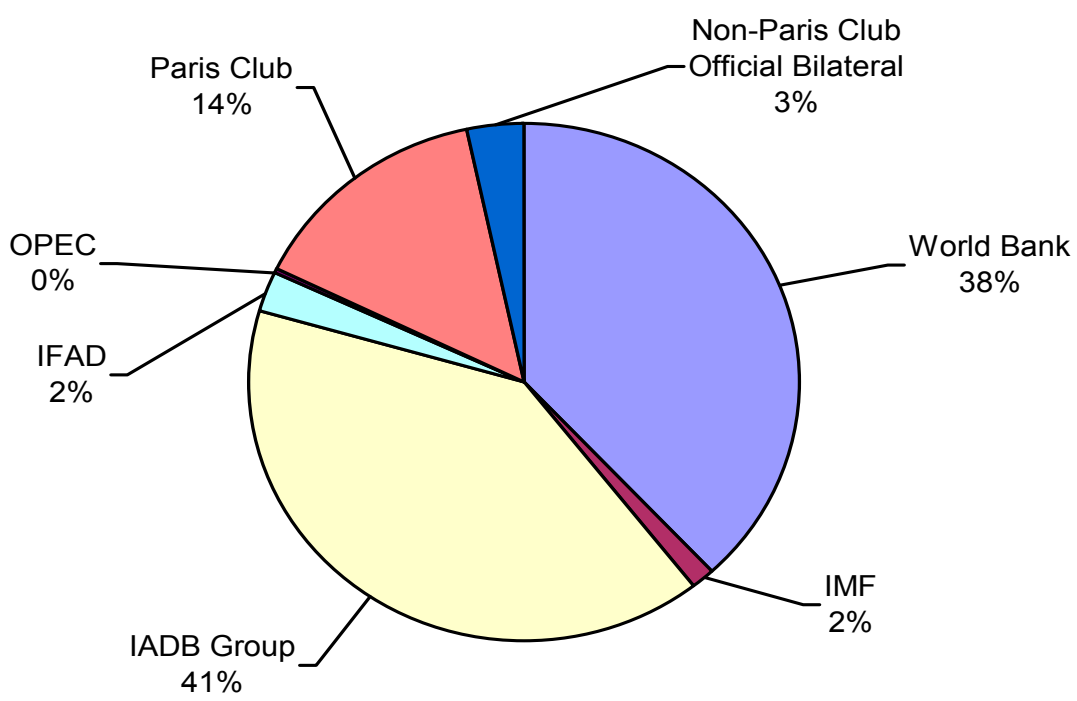

End September-2008

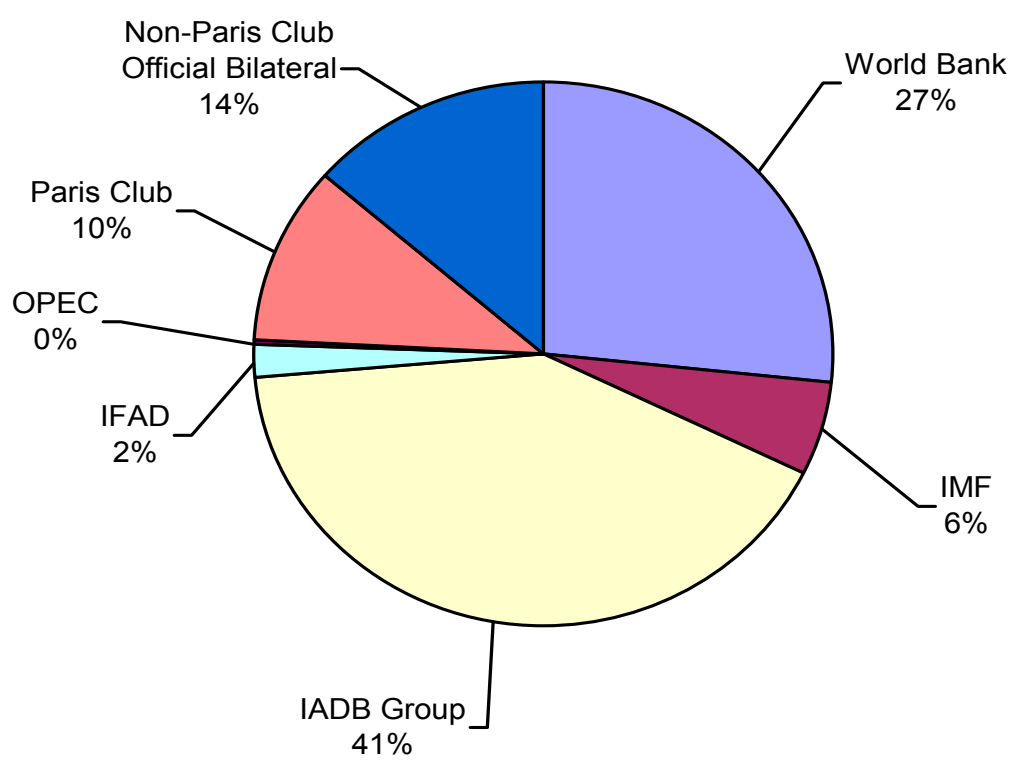

Source: Haitian authorities.

CInternational Monetary Fund. Not for Redistribution 


\section{Figure 2. Haiti: External Debt and Debt Service Indicators for Medium- and Long-Term Public Sector Debt, 2007/08 - 2027/28}

Net Present Value of External Debt-to-Exports
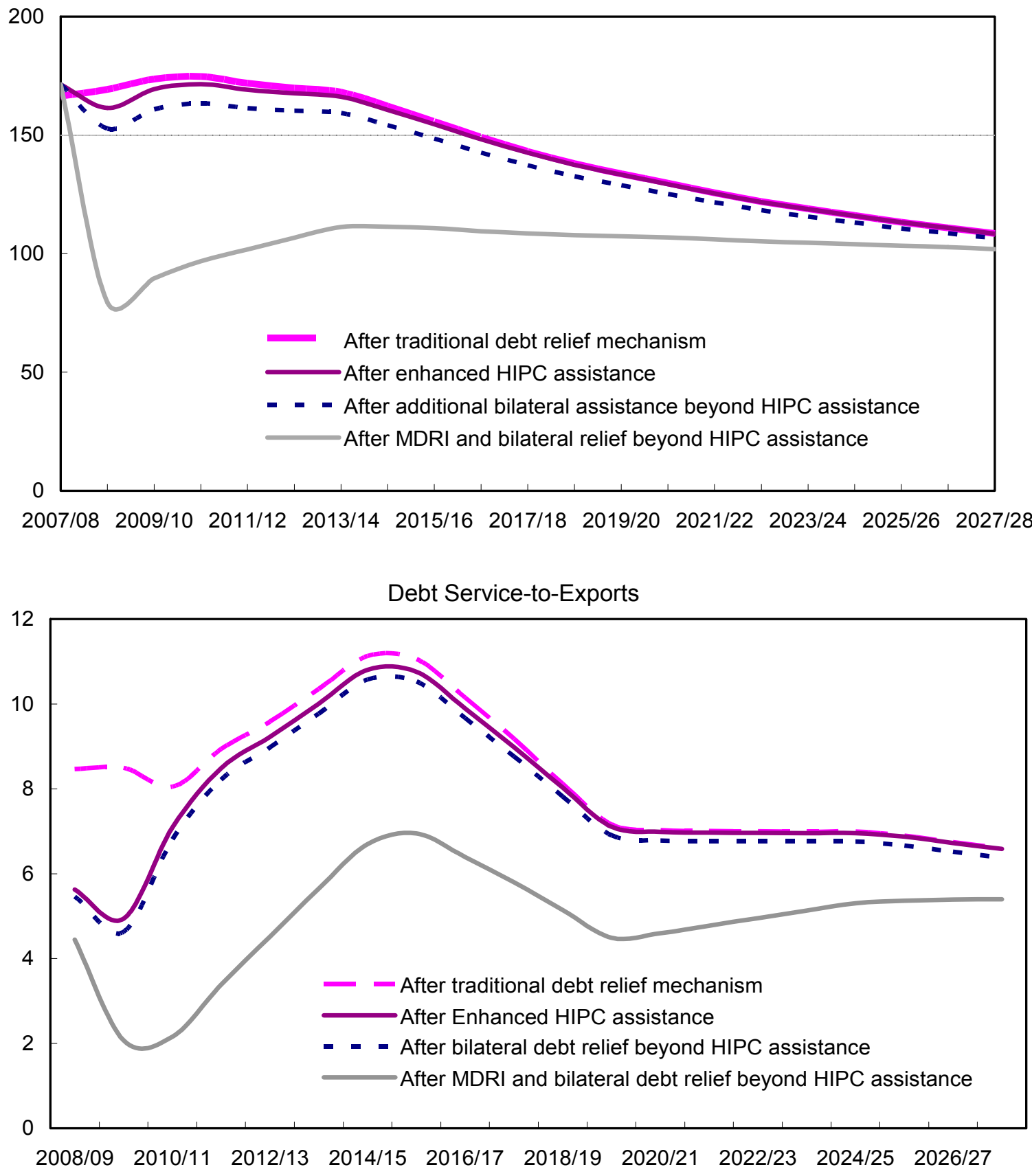

Sources: Haitian authorities; and staff estimates.

(CInternational Monetary Fund. Not for Redistribution 
Figure 3. Haiti: Sensitivity Analysis, 2008/09 - 2027/08
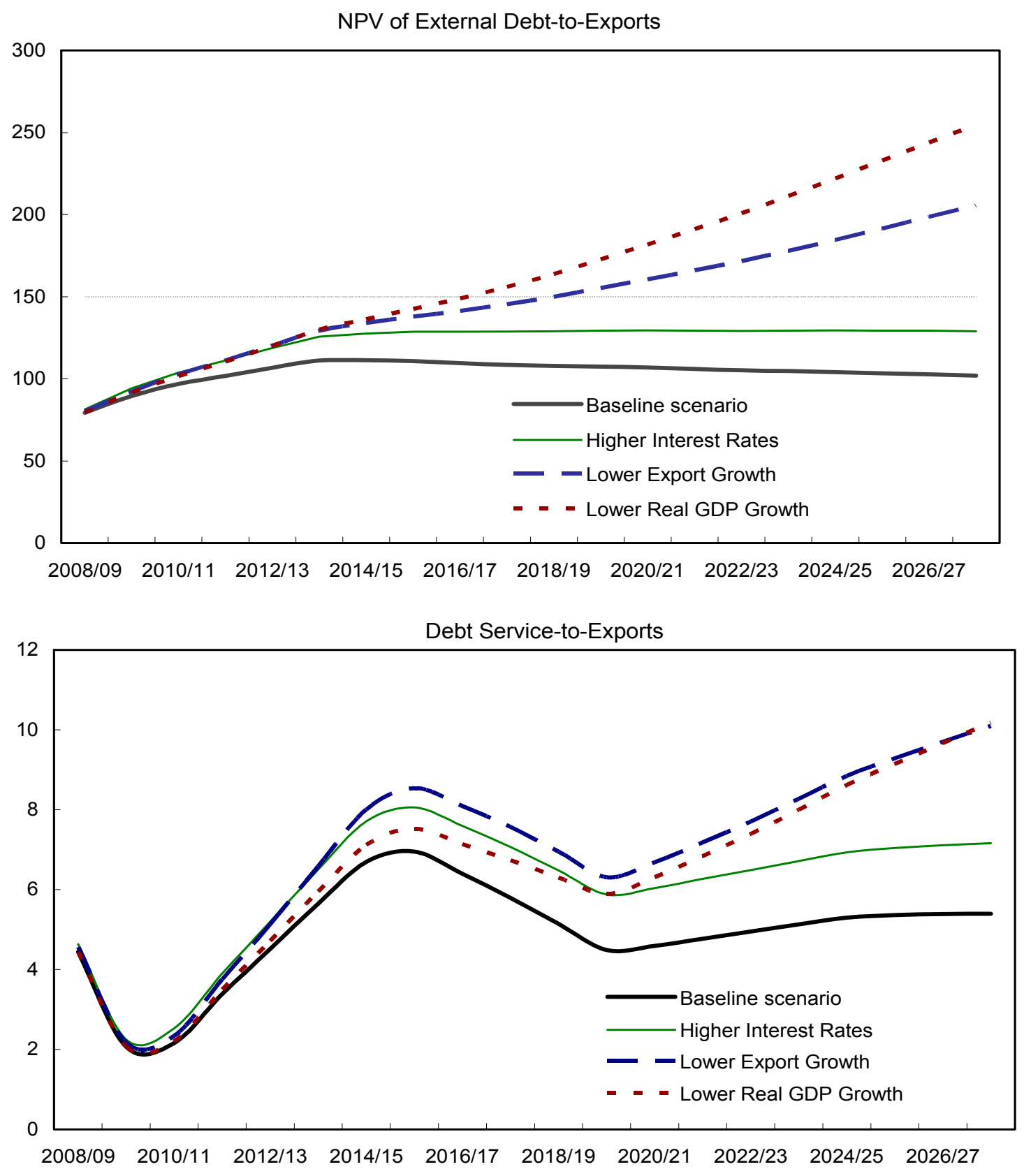

Sources: Haiti authorities; and staff estimates. 
Table 1. Haiti: Revised Nominal Stocks and Net Present Value of Debt at Decision Point by Creditor Groups

(As of end-September 2005 1/)

\begin{tabular}{|c|c|c|c|c|c|c|c|c|c|c|c|c|}
\hline & \multicolumn{4}{|c|}{ Nominal Debt Stock } & \multicolumn{4}{|c|}{ NPV of Debt Before Rescheduling 2/ } & \multicolumn{4}{|c|}{ NPV of Debt After Rescheduling 2/3/ } \\
\hline & \multicolumn{2}{|c|}{ At Decision Point } & \multicolumn{2}{|c|}{$\begin{array}{c}\text { Revised At } \\
\text { Completion Point }\end{array}$} & \multicolumn{2}{|c|}{ At Decision Point } & \multicolumn{2}{|c|}{$\begin{array}{c}\text { Revised At } \\
\text { Completion Point } \\
\end{array}$} & \multicolumn{2}{|c|}{ At Decision Point } & \multicolumn{2}{|c|}{$\begin{array}{c}\text { Revised At } \\
\text { Completion Point }\end{array}$} \\
\hline & US\$ million & $\begin{array}{l}\text { Percent } \\
\text { of total }\end{array}$ & US\$ million & $\begin{array}{l}\text { Percent } \\
\text { of total }\end{array}$ & US\$ million & $\begin{array}{l}\text { Percent } \\
\text { of total }\end{array}$ & US\$ million & $\begin{array}{l}\text { Percent } \\
\text { of total }\end{array}$ & US\$ million & $\begin{array}{l}\text { Percent } \\
\text { of total }\end{array}$ & US\$ million & $\begin{array}{l}\text { Percent } \\
\text { of total }\end{array}$ \\
\hline Total & $1,336.3$ & 100 & $1,337.2$ & 100 & 932.9 & 100 & 934.0 & 100 & 928.3 & 100 & 928.8 & 100 \\
\hline Multilateral & $1,097.8$ & 82 & $1,097.8$ & 82 & 750.6 & 80 & 750.6 & 80 & 793.5 & 85 & 793.5 & 85 \\
\hline World Bank & 507.1 & 38 & 507.1 & 38 & 316.3 & 34 & 316.3 & 34 & 349.4 & 38 & 349.4 & 38 \\
\hline IMF & 21.4 & 2 & 21.4 & 2 & 20.6 & 2 & 20.6 & 2 & 20.6 & 2 & 20.6 & 2 \\
\hline IADB Group & 533.9 & 40 & 533.9 & 40 & 389.9 & 42 & 389.9 & 42 & 399.6 & 43 & 399.6 & 43 \\
\hline IFAD & 31.7 & 2 & 31.7 & 2 & 20.3 & 2 & 20.3 & 2 & 20.3 & 2 & 20.3 & 2 \\
\hline OPEC & 3.7 & 0 & 3.7 & 0 & 3.4 & 0 & 3.4 & 0 & 3.4 & 0 & 3.4 & 0 \\
\hline Official bilateral and commercial & 238.5 & 18 & 239.4 & 18 & 182.2 & 20 & 183.3 & 20 & 134.8 & 15 & 135.3 & 14.6 \\
\hline Paris Club & 192.7 & 14 & 193.6 & 14 & 145.7 & 16 & 146.6 & 16 & 98.4 & 11 & 98.8 & 11 \\
\hline Canada & 2.0 & 0 & 2.0 & 0 & 2.1 & 0 & 2.1 & 0 & 2.1 & 0 & 2.1 & 0 \\
\hline EEC IDA administered & 4.0 & 0 & 4.0 & 0 & 2.7 & 0 & 2.7 & 0 & 1.5 & 0 & 1.5 & 0 \\
\hline France & 64.1 & 5 & 64.1 & 5 & 59.7 & 6 & 59.7 & 6 & 45.7 & 5 & 45.7 & 5 \\
\hline Italy & 68.9 & 5 & 69.6 & 5 & 44.2 & 5 & 44.9 & 5 & 24.2 & 3 & 24.4 & 3 \\
\hline Spain & 38.6 & 3 & 38.9 & 3 & 24.1 & 3 & 24.3 & 3 & 13.6 & 1 & 13.7 & 1 \\
\hline United States & 15.1 & 1 & 15.1 & 1 & 13.0 & 1 & 13.0 & 1 & 11.4 & 1 & 11.4 & 1 \\
\hline Non-Paris Club Official Bilateral & 45.8 & 3 & 45.8 & 3 & 36.5 & 4 & 36.7 & 4 & 36.4 & 4 & 36.6 & 4 \\
\hline Taiwan, Province of China & 45.7 & 3 & 45.7 & 3 & 36.3 & 4 & 36.5 & 4 & 36.3 & 4 & 36.5 & 4 \\
\hline República Bolivariana de Venezuela & 0.1 & 0 & 0.1 & 0 & 0.1 & 0 & 0.1 & 0 & 0.0 & 0 & 0.0 & 0 \\
\hline
\end{tabular}

$1 /$ Information based on latest data available at completion point.

2/ Includes a stock-of-debt operation on Naples terms at end-September 2005; and comparable treatment by other official bilateral creditors on eligible debt (pre-cutoff and non-ODA)

$3 /$ The NPV of debt to the official bilateral creditors has been revised upward at the time of the completion point due to better documentation. 
Table 2. Haiti: Estimated Assistance at Decision Point (Amended) 1/

(In millions of U.S. dollars in end-September 2005 NPV terms, unless otherwise indicated) $2 /$

\begin{tabular}{|c|c|c|c|c|c|c|}
\hline & Total & Multilaterals & Bilaterals & $\begin{array}{l}\text { Commercial } \\
\text { Banks }\end{array}$ & $\begin{array}{l}\text { Common } \\
\text { Reduction } \\
\text { Factor 3/ } \\
\text { (Percent) } \\
\end{array}$ & $\begin{array}{r}\text { Memo item: } \\
\text { Required NPV debt } \\
\text { reduction on } \\
\text { comparable treatment on } \\
\text { bilateral debt based }\end{array}$ \\
\hline NPV of debt-to-exports target (in percent) & 150.0 & & & & & \\
\hline $\begin{array}{l}\text { Assistance (decision point document) } \\
\text { Assistance (potential revision) } 5 /\end{array}$ & $\begin{array}{l}140.3 \\
132.1\end{array}$ & $\begin{array}{l}120.0 \\
112.9\end{array}$ & $\begin{array}{l}20.4 \\
19.3\end{array}$ & - & $\begin{array}{l}15.1 \\
14.2\end{array}$ & \\
\hline Memorandum items: & & & & & & \\
\hline $\begin{array}{l}\text { NPV of debt } 6 / 7 / \\
\text { Paris Club creditors } \\
\text { Of which: pre-cutoff date non-ODA debt } \\
\text { Non-Paris Club creditors } \\
\text { Of which: pre-cutoff date non-ODA debt } \\
\text { Three-year export average } 8 / \\
\text { NPV of debt-to-export ratio (percent) } 8 / \\
\text { Revised } \\
\text { Decision point document }\end{array}$ & $\begin{array}{r}928.8 \\
98.8 \\
50.7 \\
36.6 \\
0.0 \\
531.1 \\
174.9 \\
176.7\end{array}$ & 793.5 & 135.3 & & & \\
\hline $\begin{array}{l}\text { Bilateral Creditors: } \\
\text { of which: pre-cod ODA } \\
\text { pre-cod non-ODA } \\
\text { post-cod debt }\end{array}$ & & & & & & $\begin{array}{l}15.1 \\
72.0 \\
15.1\end{array}$ \\
\hline
\end{tabular}

1/ Assumes proportional burden-sharing as described in "HIPC Initiative: Estimated Costs and Burden-Sharing Approaches" (EBS/97/127; 7/7/97, and IDA/SEC M97-306;7/7/97), that is, after full application of traditional debt relief mechanisms.

2/ Using six-month backward-looking discount rates at end-September 2005, and end-September 2005 exchange rates.

3/ Each creditor's NPV reduction in percent of its exposure at the decision point (after hypothetical Naples stock at the end of the base year).

4/ Includes traditional debt relief; a hypothetical stock-of-debt on Naples terms with comparable treatment from non Paris Club creditors.

5/ Despite a lower revised amount of HIPC assistance at the time of the completion point, the amount of HIPC assistance committed at the time

of the decision point will not be revised downward and remains at US\$140.3 million in NPV terms.

6/ After a hypothetical stock-of-debt operation on Naples terms at end September-2005.

7/ Based on latest data available at the decision point after full application of traditional debt relief mechanisms.

8/ Based on the latest annual data at the completion point on the three-year average of exports of goods and nonfactor services (i.e., 2002/03-2004/05). 
Table 3. Haiti: Comparison of Discount Rate and Exchange Rate Assumptions

\begin{tabular}{|c|c|c|c|c|}
\hline & \multicolumn{2}{|c|}{$\begin{array}{c}\text { Discount Rates 1/ 2/ } \\
\text { (in percent per annum) }\end{array}$} & \multicolumn{2}{|c|}{$\begin{array}{c}\text { Exchange Rates 3/ } \\
\text { (Currency per U.S. dollar) }\end{array}$} \\
\hline & $\begin{array}{l}\text { At decision point } \\
\text { End-September } 2005\end{array}$ & $\begin{array}{l}\text { At completion point } \\
\text { End-September } 2008\end{array}$ & $\begin{array}{l}\text { At decision point } \\
\text { End-September } 2005\end{array}$ & $\begin{array}{l}\text { At completion point } \\
\text { End-September } 2008\end{array}$ \\
\hline \multicolumn{5}{|l|}{ Currency } \\
\hline Canadian Dollar & 4.795 & 4.422 & 1.163 & 1.060 \\
\hline Danish Kroner & 4.058 & 5.373 & 6.197 & 5.217 \\
\hline Euro & 4.112 & 5.147 & 0.830 & 0.699 \\
\hline Great Britain Sterling & 5.505 & 5.705 & 0.566 & 0.556 \\
\hline Japanese Yen & 1.850 & 2.200 & 113.150 & 104.300 \\
\hline Norwegian Kroner & 4.207 & 5.725 & 6.540 & 5.830 \\
\hline Special Drawing Rights & 4.349 & 4.580 & 0.690 & 0.642 \\
\hline Swedish Kroner & 4.205 & 5.140 & 7.746 & 6.848 \\
\hline Swiss Franc & 2.815 & 4.012 & 1.290 & 1.102 \\
\hline United States Dollar & 5.053 & 4.352 & 1.000 & 1.000 \\
\hline Venezuelan Bolivar & 4.349 & 4.580 & 2.147 & 2.147 \\
\hline \multicolumn{5}{|l|}{ Memorandum item: } \\
\hline Paris Club cutoff date & \multicolumn{2}{|c|}{ October 1, 1993} & & \\
\hline Decision point & \multicolumn{2}{|c|}{ December 12, 2006} & & \\
\hline
\end{tabular}

Sources: European Central Bank; IMF, International Financial Statistics; OECD; and staff estimates.

$1 /$ The discount rates used are the average commercial interest reference rates (CIRRs) for the respective currencies over the six-month period ending in September 2008 for the completion point and in September 2005 for the decision point.

2/ For all Euro area currencies, the Euro CIRR is used. For all currencies for which the CIRRs are not available, the SDR discount rate is used as a proxy.

3/ End-of-period exchange rates. 
Table 4. Haiti: Status of Creditor Participation Under the Enhanced HIPC Initiative.

\begin{tabular}{|c|c|c|c|c|}
\hline & $\begin{array}{l}\text { Debt Relief in } \\
\text { NPV Terms } \\
\text { (US\$ mil.) }\end{array}$ & $\begin{array}{l}\text { Percentage } \\
\text { of Total } \\
\text { Assistance }\end{array}$ & $\begin{array}{l}\text { Satisfactory } \\
\text { Reply to } \\
\text { Participate in } \\
\text { Initiative }\end{array}$ & Modalities to Deliver Debt Relief \\
\hline World Bank & 52.8 & 37.6 & Yes & $\begin{array}{l}\text { Interim debt relief was equivalent to a } 50 \text { percent reduction in Haiti's } \\
\text { debt service to IDA, or US } \$ 9.86 \text { million in NPV terms. After } \\
\text { completion point, the remaining assistance of US } \$ 9.86 \text { million in } \\
\text { NPV will be provided through a } 51.6 \text { percent reduction in debt } \\
\text { service payments. }\end{array}$ \\
\hline IMF & 3.1 & 2.2 & Yes & $\begin{array}{l}\text { Interim debt relief was equivalent to US } \$ 0.45 \text { million nominal } \\
\text { reduction in Haiti's debt service to the IMF. Upon reaching the } \\
\text { completion point, the remaining US } \$ 3 \text { million in HIPC relief will be } \\
\text { delivered via a stock of debt operation. }\end{array}$ \\
\hline IADB Group & 60.4 & 43.1 & Yes & $\begin{array}{l}\text { During the interim period, debt service was reduced by about } \\
\text { US } \$ 27.25 \text { million in NPV terms. Upon reaching the completion } \\
\text { point, the remaining US } \$ 23.47 \text { million in NPV terms will be } \\
\text { delivered. }\end{array}$ \\
\hline IFAD & 3.1 & 2.2 & Yes & $\begin{array}{l}100 \text { percent of debt service relief, equal to US } \$ 3 \text { million in NPV } \\
\text { terms, will be provided until the target is reached. Relief will begin at } \\
\text { the completion point. }\end{array}$ \\
\hline OPEC & 0.5 & 0.4 & Yes & $\begin{array}{l}\text { HIPC debt relief will be provided through the restructuring of existing } \\
\text { loans on more concessional terms. }\end{array}$ \\
\hline Total multilateral & 120.0 & 85.5 & & \\
\hline Paris Club creditors & 14.9 & 10.6 & yes & $\begin{array}{l}\text { Paris Club creditors have provided relief on Cologne terms in the } \\
\text { interim period. }\end{array}$ \\
\hline Non-Paris Club creditors & 5.5 & 3.9 & & \\
\hline República Bolivariana de Venezuela & 0.0 & 0.0 & no & $\begin{array}{l}\text { Haiti has made the last payment on the loan from the Venezuelan } \\
\text { trust fund. They have also contracted concessional external } \\
\text { financing from PetroCaribe in the interim period. No interim debt } \\
\text { relief has been provided. }\end{array}$ \\
\hline Total bilateral & 20.4 & 14.5 & & \\
\hline Total & 140.3 & 100.0 & & \\
\hline
\end{tabular}

Sources: Haitian authorities, and staff estimates. 
Table 5. Haiti: Nominal and Net Present Value of External Debt outstanding at End-September 2008 1/ (In millions of US\$, unless otherwise indicated)

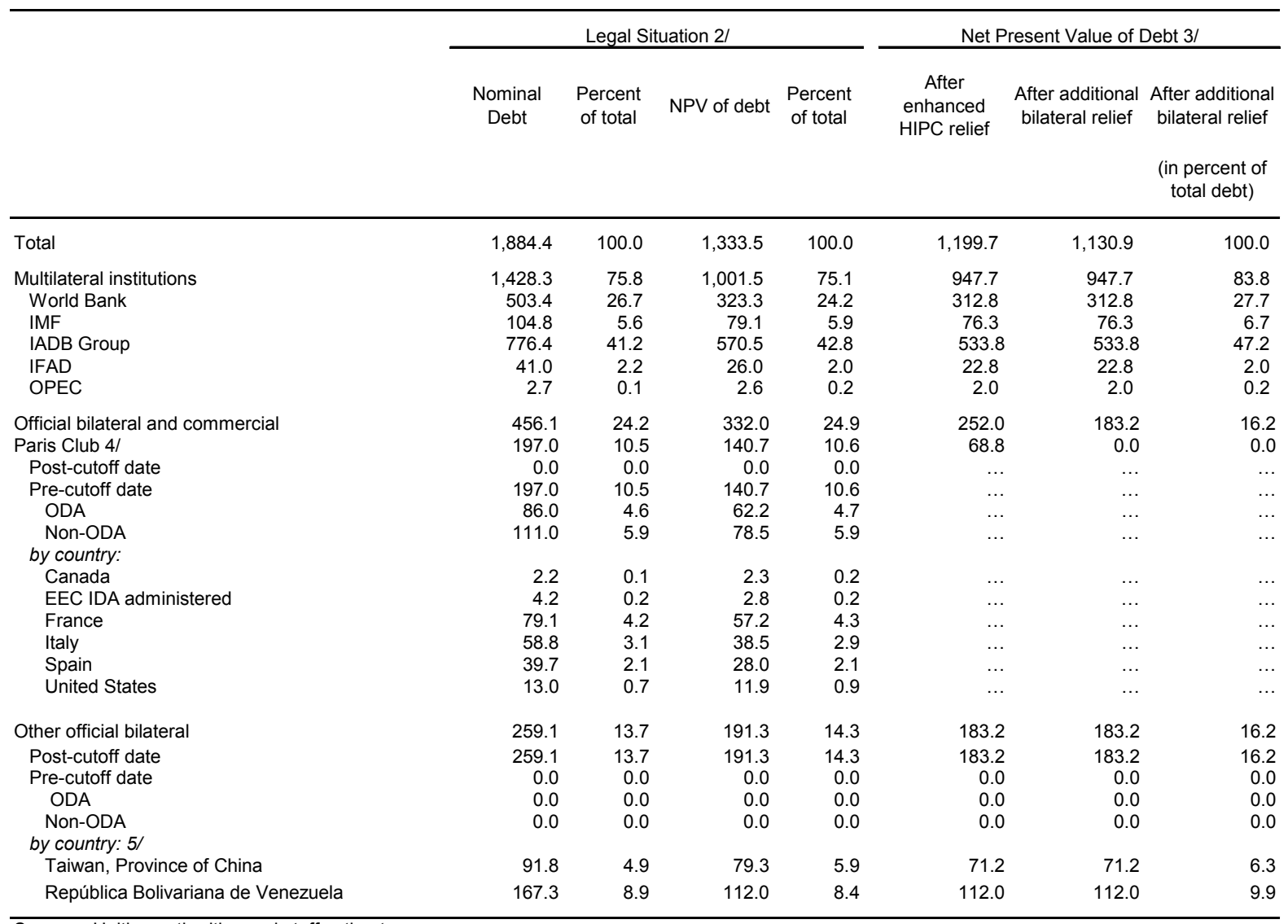

Sources: Haitian authorities and staff estimates.

1/ Figures are based on data as of end September-2008.

2/ Includes Naples flows, as well as Cologne flow and cancellations in the interim period from Paris Club creditors

$3 /$ Assumes full delivery of HIPC assistance as of end September-2008.

4/ Paris Club creditors deliver their share of assistance as a group. Actual delivery modalities are defined on a case-by-case basis.

5/ Haiti has contracted new borrowings from Taiwan, Province of China and República Bolivariana de Venezuela in the interim period. The disbursements totalled US $\$ 50$ million and US\$167 million from Taiwan, Province of China and República Bolivariana de Venezuela respectively as of end September-2008 
Table 6. Haiti: Net Present Value of External Debt, 2007/08 - 2027/28 1/

(In millions of U.S. dollars, unless otherwise indicated)

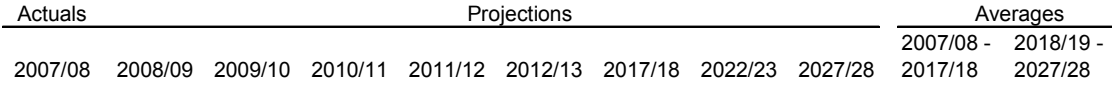

I. After traditional debt-relief mechanisms $2 /$

1. NPV of total debt $(2+4)$

2. NPV of outstanding debt

Official bilateral and commercia

\begin{tabular}{rrrrrrrrr}
$1,281.8$ & $1,367.2$ & $1,453.0$ & $1,524.1$ & $1,605.9$ & $1,698.6$ & $2,046.8$ & $2,574.8$ & $3,360.5$ \\
\hline $1,281.8$ & $1,268.9$ & $1,253.7$ & $1,232.5$ & $1,203.5$ & $1,164.9$ & 879.4 & 655.1 & 414.9
\end{tabular}

Other official bilateral

Multilateral

World Bank Group

IMF

IADB Group

IFAD

OPEC

$\begin{array}{rr}1,281.8 & 1,2 \\ 280.3 & 28 \\ 92.0 & \\ 188.3 & 190 \\ 1,001.5 & 986 \\ 323.3 & 3 \\ 79.1 & \\ 570.5 & 5 \\ 26.0 & \\ 2.6 & \end{array}$

$\begin{array}{rr}1,268.9 & 1,25 \\ 282.0 & 283 \\ 91.8 & \\ 190.1 & 191 \\ 986.9 & 970 \\ 318.0 & 311 \\ 82.2 & \\ 559.1 & 5 \\ 25.7 & \\ 1.9 & \end{array}$

283.3

$232.5 \quad 1,203.5$

$1,164.9$
262.0

879.4
210.3

$\begin{array}{rr}655.1 & 414.9\end{array}$

$\begin{array}{ll}653.2 & 104.5\end{array}$

$1,681.7$

$1,125.7$

$\begin{array}{rrr}279.0 & 271.2 & 262.0 \\ 91.3 & 90.4 & 89.4\end{array}$

81.5

$\begin{array}{lr}77.0 & 61.5\end{array}$

$\begin{array}{lllll}191.7 & 187.7 & 180.8 & 172.6 & 128.8\end{array}$

$953.5 \quad 932.3 \quad 902.9$

$\begin{array}{lll}304.5 & 297.1 \quad 289.6\end{array}$

$\begin{array}{lll}88.8 & 88.0 & 79.3\end{array}$

669.1
236.3

$86.2 \quad 43.1$

$491.9 \quad 310.3$

$\begin{array}{rr}167.5 & 89.4\end{array}$

$\begin{array}{lll}0.0 & 0.0 & 0.0\end{array}$

$309.4 \quad 211.2$

$534.6 \quad 522.2 \quad 510.0$

413.1

211.2
9.7

0.1

0.0

0.0

$256.0 \quad 155.7$

$\begin{array}{ll}167.7 & 81.7\end{array}$

$869.6 \quad 473.0$

$285.8 \quad 158.4$

$58.2-0.0$

300.2

$23.2 \quad 14.4$

II. After enhanced HIPC assistance

1. NPV of total debt $(2+4)$

2. NPV of outstanding debt

Official bilateral and commercial Paris Club Other official bilateral

Multilateral

World Bank Group

$\begin{array}{lll}1,320.5 & 1,304.2 \quad 1,417\end{array}$

$\begin{array}{llllll}1,496.1 & 1,581.1 & 1,676.3 & 2,038.8 & 2,570.2 & 3,358.9\end{array}$

$\begin{array}{rrrrrrrrr}1,320.5 & 1,205.9 & 1,218.5 & 1,204.6 & 1,178.6 & 1,142.6 & 871.4 & 650.5 & 413.3\end{array}$

$1,663.3 \quad 2,682.4$

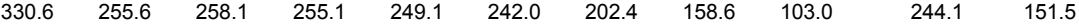

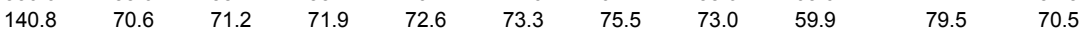

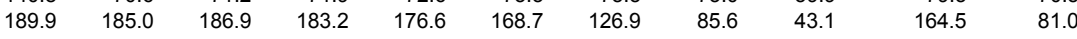

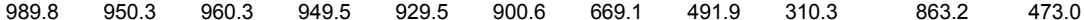

$323.3-310.0-311.5$

IMF

IADB Group

IFAD

OPEC

$\begin{array}{rrr}78.9 & 79.4 & 82.6\end{array}$

$304.5 \quad 297.1 \quad 289.6$

$\begin{array}{rrr}304.5 & 297.1 & 289.6 \\ 85.8 & 85.2 & 77.0\end{array}$

236.3

$167.5 \quad 89.4$

$\begin{array}{rr}285.1 & 158.4 \\ 56.5 & 0.0\end{array}$

$\begin{array}{lrrrrrrrr}559.0 & 537.0 & 542.1 & 534.6 & 522.2 & 510.0 & 413.1 & 309.4 & 211.2\end{array}$

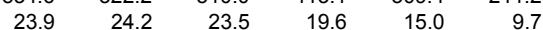

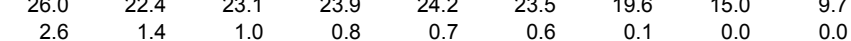

$\begin{array}{rrrrrrrrr}2.6 & 1.4 & 1.0 & 0.8 & 0.7 & 0.6 & 0.1 & 0.0 & 0.0 \\ 1,199.7 & 1,304.2 & 1,417.8 & 1,496.1 & 1,581.1 & 1,676.3 & 2,038.8 & 2,570.2 & 3,358.9\end{array}$

$\begin{array}{llllllllr}947.7 & 950.3 & 960.3 & 949.5 & 929.5 & 900.6 & 669.1 & 491.9 & 310.3\end{array}$

Multilateral (end-sept 2008)

Bilateral

$252.0 \quad 255.6 \quad 258.1$

$949.5 \quad 929.5$

$\begin{array}{rr}255.6 & 258.1 \\ 977.2 & 1,042.5\end{array}$

$1,104.5 \quad 1,144.5$

$242.0 \quad 202.4$

491.9

103.0

498.1

22.6

300.2

14.4

$\begin{array}{rr}0.8 & 0.0 \\ 1,652.3 & 2.682 .4\end{array}$

$859.4 \quad 473.0$

$236.9 \quad 151.5$

$1,208.0 \quad 1,367.2$

III. After bilateral debt relief beyond HIPC assistance 4/

1. NPV of total debt $(2+4)$

2. NPV of outstanding debt

Official bilateral

Paris Club

Other official bilateral

Multilateral

World Bank Group

IMF

IADB Group

IFAD

OPEC

$\begin{array}{lllllllll}1,320.5 & 1,233.6 & 1,346.6 & 1,424.2 & 1,508.5 & 1,603.0 & 1,963.3 & 2,497.2 & 3,299.0\end{array}$

$1,596.5$

$1,040.5$

$2,611.9$

554.1

$\begin{array}{llllllllr}1,320.5 & 1,135.3 & 1,147.2 & 1,132.7 & 1,106.1 & 1,069.3 & 796.0 & 577.5 & 353.4\end{array}$

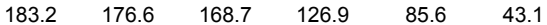

$\begin{array}{rrrrrrrrr}140.8 & 0.0 & 0.0 & 0.0 & 0.0 & 0.0 & 0.0 & 0.0 & 0.0 \\ 189.9 & 185.0 & 186.9 & 183.2 & 176.6 & 168.7 & 126.9 & 85.6 & 43.1\end{array}$

$\begin{array}{rrrrrrrrr}189.9 & 185.0 & 186.9 & 183.2 & 176.6 & 168.7 & 126.9 & 85.6 & 43.1 \\ 989.8 & 950.3 & 960.3 & 949.5 & 929.5 & 900.6 & 669.1 & 491.9 & 310.3\end{array}$

12.8

164.5

863.2

285.1

$\begin{array}{llllll}304.5 & 297.1 & 289.6 & 236.3 & 167.5 & 89.4\end{array}$

$\begin{array}{rrrrrrrrr}78.9 & 79.4 & 82.6 & 85.8 & 85.2 & 77.0 & 0.0 & 0.0 & 0.0 \\ 559.0 & 537.0 & 542.1 & 534.6 & 522.2 & 510.0 & 413.1 & 309.4 & 211.2\end{array}$

$\begin{array}{rrrrrrrrr}323.3 & 310.0 & 311.5 & 304.5 & 297.1 & 289.6 & 236.3 & 167.5 & 89.4 \\ 78.9 & 79.4 & 82.6 & 85.8 & 85.2 & 77.0 & 0.0 & 0.0 & 0.0 \\ 559.0 & 537.0 & 542.1 & 534.6 & 522.2 & 510.0 & 413.1 & 309.4 & 211.2\end{array}$

$\begin{array}{rr}167.5 & 89.4 \\ 0.0 & 0.0\end{array}$

56.5

498.1

22.6

$23.9-23.5$

26.0

$22.4 \quad 23.1$

19.6

15.0

9.7

$1,130.9 \quad 1,135.3 \quad 1,147.2$

$1,132.7 \quad 1,106.1 \quad 1,069.3$

0.1
796.0

0.0
577.5

0.0

0.8

$1,023.3$

81.0
0.0

81.0

473.0

158.4

0.0

300.2

4.4

0.0
554.1

IV. After MDRI assistance and bilateral debt relief beyond HIPC assistance

$\begin{array}{ccc}1,320.5 & 641.0 & 749.7 \\ 1,320.5 & 542.7 & 550.3\end{array}$

$1,320.5 \quad 542.7 \quad 550.3$

$\begin{array}{llllll}844.2 & 950.7 & 1,067.6 & 1,552.5 & 2,219.8 & 3,154.8\end{array}$

$1,126.2$

$2,348.0$

NPV of outstanding debt

$\begin{array}{lll}330.6 & 185.0 & 186.9 \\ 989.8 & 357.7 & 363.4\end{array}$

Multilatera

World Bank Group

IMF

IADB Group

IFAD

OPEC

3. NPV of total debt after full delivery $3 /$

$\begin{array}{rrr}323.3 & 17.2 & 17.9\end{array}$

$\begin{array}{lll}78.9 & 79.4 & 82.6\end{array}$

$\begin{array}{lllll}548.2 & 533.9 & 385.2 & 300.1 & 209.2\end{array}$

570.1

290.2

$\begin{array}{llllllr}183.2 & 176.6 & 168.7 & 126.9 & 85.6 & 43.1 & 177.3\end{array}$

$369.5 \quad 371.7 \quad 365.2 \quad 258.3=214.6 \quad 166.1$

$\begin{array}{rrrrrrrr} & \\ 18.5 & 371.7 & 365.2 & 258.3 & 214.6 & 166.1 & 392.8 & 209.1 \\ 8.1 & 19.7 & 20.7 & 20.8 & 18.2 & 47.2 & 20.2\end{array}$

$\begin{array}{llllllll}85.8 & 85.2 & 77.0 & 0.0 & 0.0 & 0.0 & 56.5 & 0.0\end{array}$

$\begin{array}{rrrrrrrrrrr}559.0 & 237.3 & 238.8 & 240.5 & 242.4 & 244.4 & 217.9 & 178.8 & 138.2 & 265.7 & 174.6 \\ 26.0 & 22.4 & 23.1 & 23.9 & 24.2 & 23.5 & 19.6 & 15.0 & 9.7 & 22.6 & 14.4\end{array}$

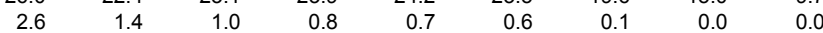

$565.3 \quad 641.0 \quad 749.7$

$382.1 \quad 357.7 \quad 363.4$

$\begin{array}{llllll}844.2 & 950.7 & 1,067.6 & 1552.5 & 2219.8 & 3,154.8\end{array}$

Multilateral

Bilateral and commercial 5/

$\begin{array}{lll}183.2 & 185.0 \quad 186.9\end{array}$

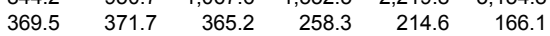

0.8

$1,057.5-2,348.0$

$337.6 \quad 209.1$

$163.9 \quad 81.0$

Memorandum items:

4. NPV of new borrowing

$98.3 \quad 199.3$

291.5

402.4

$533.7 \quad 1,167.4 \quad 1,919.7 \quad 2,945.6$

$611.6 \quad 2,057.8$

Sources: Haitian authorities; and staff estimates and projections.

$1 /$ Refers to public and publicly guaranteed external debt only and is discounted on the basis of the average commercial interest reference

rate for the respective currency, derived over the six-month period prior to the latest date for which actual data are available (September 2008).

2/ Assumes a stock-of-debt operation on Naples terms (67 percent NPV reduction) as of end September-2008, and at least comparable action by other official bilateral and commercial creditors.

$3 /$ NPV of total debt assuming the entire HIPC Initiative assistance is fully delivered as of end September-2008.

4/ Includes additional debt relief provided on a voluntary basis by the Paris Club beyond the requirements of the enhanced HIPC framework

as specified on Table 14

$5 /$ This corresponds to the situation after additional bilateral relief for Paris Club Creditors.

CInternational Monetary Fund. Not for Redistribution 
Table 7. Haiti: External Debt Service After Full Implementation of Debt-Relief Mechanisms, 2008/09 - 2027/28 (In millions of U.S. dollars, unless otherwise indicated)

\begin{tabular}{|c|c|c|c|c|c|c|c|c|c|c|}
\hline \multirow[b]{3}{*}{$\begin{array}{l}\text { After traditional debt-relief mechanisms } 1 \\
\text { Total debt service including new borrowing }\end{array}$} & \multirow[b]{2}{*}{ 2008/09 } & \multirow[b]{2}{*}{$2009 / 10$} & \multirow[b]{2}{*}{ 2010/11 } & \multirow[b]{2}{*}{$2011 / 12$} & \multirow[b]{2}{*}{$2012 / 13$} & \multirow[b]{2}{*}{ 2017/18 } & \multirow[b]{2}{*}{ 2022/23 } & \multirow[b]{2}{*}{ 2027/28 } & \multicolumn{2}{|c|}{ Annual Averages } \\
\hline & & & & & & & & & $\begin{array}{l}2008 / 09 \text { - } \\
2017 / 18 \\
\end{array}$ & $\begin{array}{l}2018 / 19- \\
2027 / 28 \\
\end{array}$ \\
\hline & 686 & & & & & & & & 109.5 & \\
\hline Total debt service on outstanding debt & 67.0 & $\begin{array}{r}73.0 \\
72.0\end{array}$ & 71.5 & 89.4 & $\begin{array}{r}91.4 \\
91.4\end{array}$ & $\begin{array}{r}91.8 \\
96.1\end{array}$ & $\begin{array}{r}159.2 \\
77.8\end{array}$ & $\begin{array}{r}220.2 \\
68.9\end{array}$ & 79.5 & $\begin{array}{l}169.2 \\
76.7\end{array}$ \\
\hline Multilateral & 59.2 & 60.6 & 60.1 & 63.8 & 71.0 & 74.9 & 60.0 & 50.6 & 72.9 & 58.6 \\
\hline World Bank Group & 20.0 & 20.9 & 21.2 & 21.2 & 21.1 & 23.8 & 23.0 & 20.4 & 21.9 & 22.6 \\
\hline & 0.5 & 0.5 & 0.5 & 4.9 & 12.8 & 8.7 & 0.0 & 0.0 & 10.8 & 0.0 \\
\hline IADB Group & 36.4 & 36.8 & 36.3 & 35.8 & 35.2 & 40.5 & 35.3 & 28.6 & 38.1 & 34.3 \\
\hline IFAD & 1.5 & 1.6 & 1.6 & 1.7 & 1.8 & 1.8 & 1.7 & 1.6 & 1.7 & 1.7 \\
\hline OPEC & 0.8 & 0.8 & 0.5 & 0.1 & 0.1 & 0.1 & 0.0 & 0.0 & 0.3 & 0.0 \\
\hline Official bilateral & 7.8 & 11.3 & 11.4 & 17.6 & 20.4 & 21.2 & 17.8 & 18.3 & 17.5 & 18.1 \\
\hline Paris Club & 4.4 & 4.4 & 4.5 & 5.1 & 5.2 & 5.8 & 5.0 & 7.2 & 5.1 & 5.5 \\
\hline Other official bilateral & 3.4 & 6.9 & 6.8 & 12.5 & 15.2 & 15.4 & 12.8 & 11.1 & 12.4 & 12.7 \\
\hline \multicolumn{11}{|l|}{ After enhanced HIPC assist } \\
\hline Total debt service including $n$ & 45.6 & 42.8 & 66.6 & 84.7 & 98.2 & 138.7 & 158.4 & 219.8 & 100.5 & 168.4 \\
\hline Total debt service on outstanding debt & 44.0 & 41.2 & 62.5 & 76.9 & 87.6 & 93.0 & 77.0 & 68.5 & 81.5 & 75.9 \\
\hline Multilateral & 39.7 & 32.3 & 53.7 & 62.4 & 70.4 & 74.9 & 60.0 & 50.6 & 67.0 & 58.6 \\
\hline World Bank Group & 17.0 & 12.6 & 21.2 & 21.2 & 21.1 & 23.8 & 23.0 & 20.4 & 20.8 & 22.6 \\
\hline IMF & 0.3 & 0.5 & 0.5 & 4.5 & 12.2 & 8.7 & 0.0 & 0.0 & 10.5 & 0.0 \\
\hline IADB Group & 20.2 & 18.5 & 31.3 & 35.8 & 35.2 & 40.5 & 35.3 & 28.6 & 34.2 & 34.3 \\
\hline IFAD & 1.4 & 0.3 & 0.3 & 0.7 & 1.8 & 1.8 & 1.7 & 1.6 & 1.4 & 1.7 \\
\hline OPEC & 0.7 & 0.4 & 0.3 & 0.1 & 0.1 & 0.1 & 0.0 & 0.0 & 0.2 & 0.0 \\
\hline Official bilateral & 4.3 & 8.8 & 8.8 & 14.5 & 17.2 & 18.1 & 17.0 & 17.9 & 14.4 & 17.3 \\
\hline Paris Club & 1.3 & 2.7 & 2.7 & 2.7 & 2.7 & 3.4 & 4.5 & 6.9 & 2.7 & 4.9 \\
\hline Other official bilateral & 2.9 & 6.2 & 6.1 & 11.8 & 14.5 & 14.7 & 12.5 & 11.0 & 11.7 & 12.4 \\
\hline \multicolumn{11}{|l|}{$\begin{array}{l}\text { After bilateral debt relief beyond HIPC } 2 \text { I } \\
\text { Total debt service including new borrowing }\end{array}$} \\
\hline Total debt service including new borrowing & 44.3 & 40.1 & 63.9 & 82.0 & 95.5 & 135.3 & 154.0 & 212.9 & 97.8 & 163.5 \\
\hline Total debt service on outstanding debt & 42.6 & 38.5 & 59.8 & 74.2 & 84.9 & 89.7 & 72.6 & 61.6 & 78.8 & 71.0 \\
\hline Multilateral & 39.7 & 32.3 & 53.7 & 62.4 & 70.4 & 74.9 & 60.0 & 50.6 & 67.0 & 58.6 \\
\hline Official bilateral & 2.9 & 6.2 & 6.1 & 11.8 & 14.5 & 14.7 & 12.5 & 11.0 & 11.7 & 12.4 \\
\hline Paris Club & 0.0 & 0.0 & 0.0 & 0.0 & 0.0 & 0.0 & 0.0 & 0.0 & 0.0 & 0.0 \\
\hline Other official bilateral & 2.9 & 6.2 & 6.1 & 11.8 & 14.5 & 14.7 & 12.5 & 11.0 & 11.7 & 12.4 \\
\hline \multicolumn{11}{|c|}{ After MDRI assistance and bilateral debt relief beyond HIPC assistance } \\
\hline Total debt service including new borrowing & 36.0 & 18.0 & 20.3 & 33.8 & 48.0 & 89.5 & 112.7 & 180.1 & 57.5 & 123.7 \\
\hline Total debt service on outstanding debt & 34.4 & 16.3 & 16.2 & 26.0 & 37.5 & 43.9 & 31.2 & 28.8 & 38.4 & 31.2 \\
\hline Multilateral & 31.5 & 10.1 & 10.0 & 14.2 & 22.9 & 29.1 & 18.7 & 17.8 & 26.7 & 18.8 \\
\hline World Bank Group & 13.9 & 0.1 & 0.2 & 0.2 & 0.2 & 1.0 & 0.9 & 1.6 & 1.8 & 1.2 \\
\hline & 0.3 & 0.5 & 0.5 & 4.5 & 12.2 & 8.7 & 0.0 & 0.0 & 10.5 & 0.0 \\
\hline IADB Group & 15.2 & 8.8 & 8.7 & 8.6 & 8.6 & 17.6 & 16.1 & 14.6 & 12.8 & 15.9 \\
\hline IFAD & 1.4 & 0.3 & 0.3 & 0.7 & 1.8 & 1.8 & 1.7 & 1.6 & 1.4 & 1.7 \\
\hline OPEC & 0.7 & 0.4 & 0.3 & 0.1 & 0.1 & 0.1 & 0.0 & 0.0 & 0.2 & 0.0 \\
\hline Official bilateral $2 /$ & 2.9 & 6.2 & 6.1 & 11.8 & 14.5 & 14.7 & 12.5 & 11.0 & 11.7 & 12.4 \\
\hline \multicolumn{11}{|l|}{ Memorandum items: } \\
\hline Debt service of new borrowing & 1.6 & 1.7 & 4.1 & 7.8 & 10.6 & 45.6 & 81.4 & 151.3 & 19.1 & 92.5 \\
\hline \multicolumn{11}{|l|}{ Nominal debt relief } \\
\hline Under the enhanced HIPC initiative & 23.0 & 30.8 & 9.0 & 4.5 & 3.8 & 3.1 & 0.8 & 0.4 & 9.0 & 0.8 \\
\hline Under the MDRI & 8.2 & 22.2 & 43.6 & 48.2 & 47.4 & 45.8 & 41.3 & 32.8 & 40.4 & 39.8 \\
\hline
\end{tabular}

Sources: Haitian authorities; and staff estimates and projections.

1/ Assumes a stock-of-debt operation on Naples terms (67 percent NPV reduction) as of end September-2008, and at least comparable action by other official bilateral

$2 /$ Includes additional debt relief provided on a voluntary basis by the Paris Club beyond the requirements of the enhanced HIPC framework. 


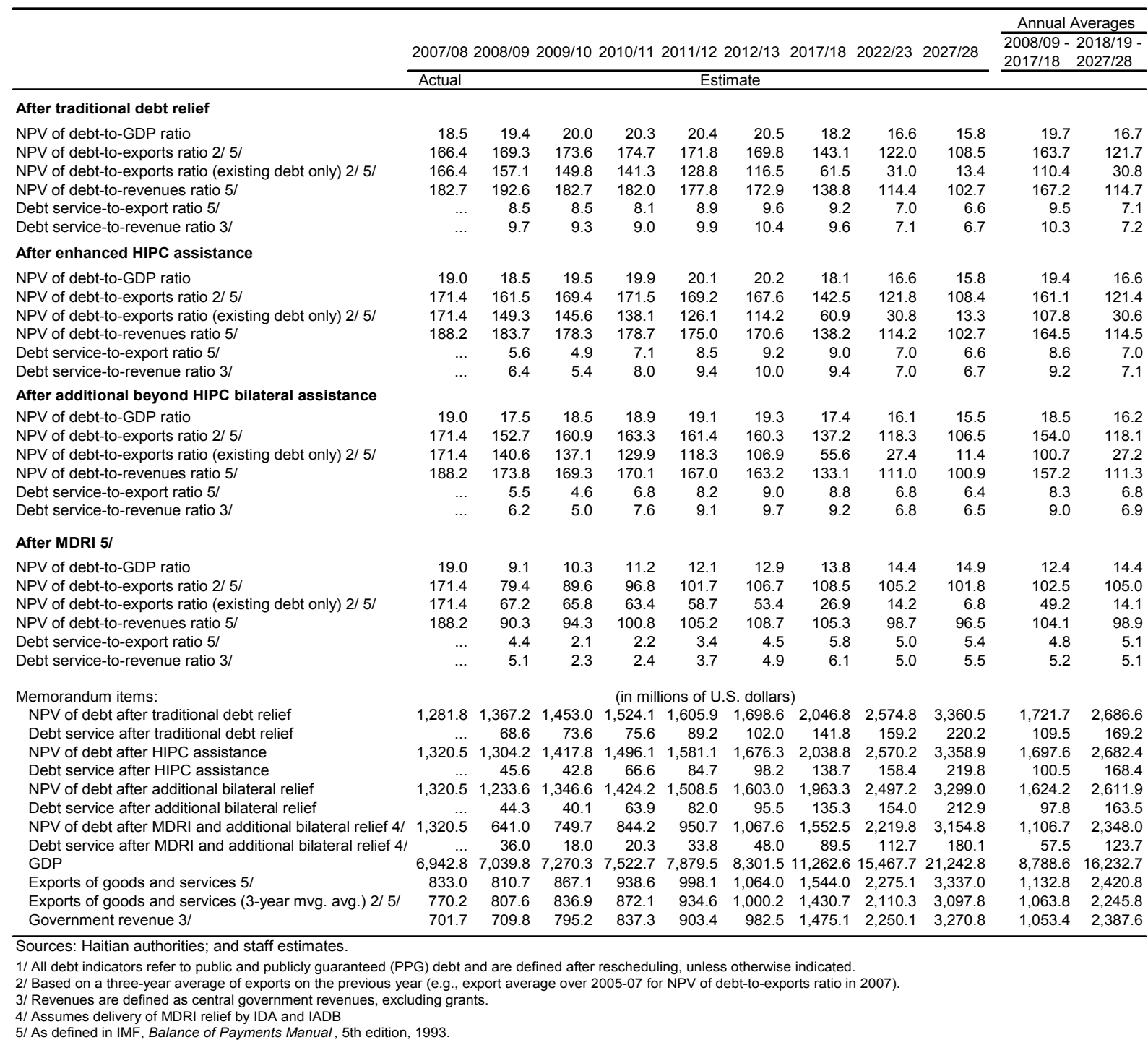




\begin{tabular}{|c|c|c|c|c|c|c|c|c|c|c|}
\hline & 2008/09 & $2009 / 10$ & 2010/11 & 2011/12 & $2012 / 132$ & 2017/18 & $2022 / 23$ & $2027 / 28$ & \multicolumn{2}{|c|}{$\begin{array}{l}\text { Averages } \\
2008 / 09-2018 / 19- \\
2017 / 18 \quad 2027 / 28\end{array}$} \\
\hline & \multicolumn{8}{|c|}{ Projections } & & \\
\hline \multicolumn{11}{|c|}{ A. Baseline Scenario } \\
\hline $\begin{array}{l}\text { NPV of debt-to-exports ratio 2/ } \\
\text { Debt service-to-export ratio }\end{array}$ & $\begin{array}{r}79.4 \\
4.4\end{array}$ & $\begin{array}{r}89.6 \\
2.1\end{array}$ & $\begin{array}{r}96.8 \\
2.2\end{array}$ & $\begin{array}{r}101.7 \\
3.4\end{array}$ & $\begin{array}{r}106.7 \\
4.5\end{array}$ & $\begin{array}{r}108.5 \\
5.8\end{array}$ & $\begin{array}{r}105.2 \\
5.0\end{array}$ & $\begin{array}{r}101.8 \\
5.4\end{array}$ & $\begin{array}{r}102.5 \\
4.8\end{array}$ & $\begin{array}{r}105.0 \\
5.1\end{array}$ \\
\hline Debt service-to-revenue ratio & 5.1 & 2.3 & 2.4 & 3.7 & 4.9 & 6.1 & 5.0 & 5.5 & & \\
\hline Memorandum items (in millions of U.S. dollars) & & & & & & & & & & \\
\hline $\begin{array}{l}\text { NPV of debt } \\
\text { of which: new debt }\end{array}$ & $\begin{array}{r}641.0 \\
98.3\end{array}$ & $\begin{array}{l}749.7 \\
199.3\end{array}$ & $\begin{array}{l}844.2 \\
291.5\end{array}$ & $\begin{array}{l}950.7 \\
402.4\end{array}$ & $\begin{array}{r}1067.6 \\
533.7\end{array}$ & $\begin{array}{l}1552.5 \\
1167.4\end{array}$ & $\begin{array}{l}2219.8 \\
1919.7\end{array}$ & $\begin{array}{l}3154.8 \\
2945.6\end{array}$ & $\begin{array}{r}1106.7 \\
611.6\end{array}$ & $\begin{array}{l}2348.0 \\
2057.8\end{array}$ \\
\hline Debt service & 36.0 & 18.0 & 20.3 & $\begin{array}{r}33.8 \\
7.8\end{array}$ & 48.0 & 89.5 & $\begin{array}{r}112.7 \\
814\end{array}$ & 180.1 & 57.5 & $\begin{array}{r}123.7 \\
92.5\end{array}$ \\
\hline & 1.6 & $\begin{array}{r}1.7 \\
869\end{array}$ & $\begin{array}{r}4.1 \\
8721\end{array}$ & & $\begin{array}{r}10.6 \\
1000\end{array}$ & $\begin{array}{r}45.6 \\
1430.7\end{array}$ & 81.4 & 151.3 & 19.1 & $\begin{array}{r}92.5 \\
2245.8\end{array}$ \\
\hline $\begin{array}{l}\text { Exports of goods and services, three year average } \\
\text { Exports of goods and services } 3 /\end{array}$ & $\begin{array}{l}807.6 \\
810.7\end{array}$ & $\begin{array}{l}836.9 \\
867.1\end{array}$ & $\begin{array}{l}872.1 \\
938.6\end{array}$ & $\begin{array}{l}934.6 \\
998.1\end{array}$ & 1000.2 & 1430.7 & $\begin{array}{l}2110.3 \\
22751\end{array}$ & 3097.8 & 1063.8 & $\begin{array}{l}2245.8 \\
2420.8\end{array}$ \\
\hline Government revenue & 709.8 & 795.2 & 837.3 & 903.4 & 982.5 & 1475.1 & 2250.1 & 3270.8 & 1053.4 & 2387.6 \\
\hline \multicolumn{11}{|c|}{ B. Sensitivity Analysis } \\
\hline \multicolumn{11}{|l|}{ Higher Interest Rates $4 /$} \\
\hline $\begin{array}{ll}\text { NPV of } \\
\text { Debt se }\end{array}$ & 81.3 & 94.2 & 103.8 & 111.1 & 118.7 & 128.7 & 129.1 & 129.0 & 114.8 & 129.2 \\
\hline $\begin{array}{l}\text { Debt service-to-export ratio } \\
\text { Debt service-to-revenue ratio }\end{array}$ & $\begin{array}{l}4.6 \\
5.3\end{array}$ & $\begin{array}{l}2.3 \\
2.5\end{array}$ & $\begin{array}{l}2.5 \\
2.8\end{array}$ & $\begin{array}{l}3.9 \\
4.3\end{array}$ & $\begin{array}{l}5.2 \\
5.6\end{array}$ & $\begin{array}{l}7.1 \\
7.4\end{array}$ & $\begin{array}{l}6.5 \\
66\end{array}$ & $\begin{array}{r}7.2 \\
7.3\end{array}$ & $\begin{array}{l}5.5 \\
5.9\end{array}$ & $\begin{array}{l}6.6 \\
6.7\end{array}$ \\
\hline Memorandum items (in millions of U.S. dollars) & & & & & & & & & & \\
\hline NPV of & 656.8 & 788.5 & 905.1 & 1038.5 & 1187.3 & 1841.7 & 2724.3 & 3996.3 & 1249.2 & $\begin{array}{l}2902 \\
2612\end{array}$ \\
\hline ebt & 114.1 & 238.1 & 352.4 & 490.3 & 653.4 & & 2424.2 & 3787.1 & 754.1 & $\begin{array}{r}2612.0 \\
162.2\end{array}$ \\
\hline Debt s & 37.6 & 19.5 & 23.7 & 39.0 & 55.3 & 109.2 & 147.7 & 239.2 & 66.7 & $\begin{array}{l}162 \\
130\end{array}$ \\
\hline ew debt & 3.2 & 3.2 & 7.6 & 13.0 & 17.8 & 65.3 & 116.4 & 210.3 & 28.3 & $\begin{aligned} 130 \\
2245\end{aligned}$ \\
\hline Exports of goods and services, thr & 807.6 & 836.9 & 872.1 & 934.6 & 1000.2 & 1430.7 & 2110.3 & 3097.8 & 1063.8 & 224 \\
\hline goods and services 3 & 810.7 & 867.1 & 938.6 & 998.1 & 1064.0 & 1544.0 & 2275.1 & 3337.0 & 1132.8 & 2420 \\
\hline Government revenue & 709.8 & 795.2 & 837.3 & 903.4 & 982.5 & 1475.1 & 2250.1 & 3270.8 & 1053.4 & 2387 \\
\hline \multicolumn{11}{|l|}{ Lower Export Growth 5/ } \\
\hline $\begin{array}{l}\text { NPV of debt-to-exports ratio } \\
\text { Debt service-to-export ratio }\end{array}$ & $\begin{array}{r}8.1 \\
4.6\end{array}$ & ${ }_{2.2}^{92.2}$ & $\begin{array}{l}102 . \\
2.3\end{array}$ & $\begin{array}{r}111.2 \\
3.8\end{array}$ & $\begin{aligned} 120.3 \\
5.1\end{aligned}$ & $\begin{array}{r}144.3 \\
7.6\end{array}$ & $\begin{array}{r}171.6 \\
7.7\end{array}$ & $\begin{array}{r}205.6 \\
10.1\end{array}$ & $\begin{array}{r}119.4 \\
5.7\end{array}$ & $\begin{array}{l}6.1 \\
8.1\end{array}$ \\
\hline Debt service-to-revenue ratio & 5.1 & 2.3 & 2.5 & 3.8 & 5.0 & 6.5 & 5.7 & 6.9 & 5.3 & \\
\hline Memorandum items (in millions of U.S. dollars) & & & & & & & & & & \\
\hline $\begin{array}{l}\text { NPV of debt } \\
\text { of which: new debt }\end{array}$ & $\begin{array}{r}641.0 \\
98.3\end{array}$ & $\begin{array}{l}752.5 \\
202.2\end{array}$ & $\begin{array}{l}851.7 \\
299.0\end{array}$ & $\begin{array}{l}964.9 \\
416.6\end{array}$ & $\begin{array}{r}1091.0 \\
557.1\end{array}$ & $\begin{array}{l}1675.9 \\
1290.7\end{array}$ & $\begin{array}{l}2596.8 \\
2296.7\end{array}$ & $\begin{array}{l}4063.2 \\
3853.9\end{array}$ & $\begin{array}{r}1149.0 \\
653.9\end{array}$ & $\begin{array}{l}2811.4 \\
2521.2\end{array}$ \\
\hline Debt & 36.0 & 18.0 & 20.3 & 34.0 & 48.4 & 92.1 & 122.9 & 21 & 58.3 & $\begin{array}{l}137 \\
106\end{array}$ \\
\hline debt & 1.6 & 1.7 & 4.2 & 8.0 & 11.0 & 48.3 & 91.7 & 18 & 19.9 & $\begin{array}{r}106.2 \\
1571.7\end{array}$ \\
\hline d services, three year average & 800.7 & 816.0 & 829.1 & 867.8 & 907.2 & 1153.2 & 1513.2 & 197 & 943.2 & $\begin{array}{l}1571 \\
1656\end{array}$ \\
\hline Exports of goods and & 789.9 & 825.1 & 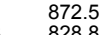 & 906.0 & 943.2 & 1217.0 & 1595.3 & 208 & 981.3 & $\begin{array}{l}1656.7 \\
2263.0\end{array}$ \\
\hline Government revenue & 707.4 & 789.8 & 828.8 & 891.2 & 966.0 & 1426.6 & 2140.7 & 3060.9 & 1031.9 & 2263.0 \\
\hline \multicolumn{11}{|l|}{ Lower Real GDP Gr } \\
\hline $\begin{array}{l}\text { to-exports ratio } 2 \\
\text { to-export ratio }\end{array}$ & $\begin{array}{r}79.4 \\
4.4\end{array}$ & $\begin{array}{r}91.5 \\
2.1\end{array}$ & $\begin{array}{r}101.6 \\
2.2\end{array}$ & $\begin{array}{r}10.3 \\
3.5\end{array}$ & $\begin{array}{r}119.9 \\
4.7\end{array}$ & $\begin{array}{r}155.9 \\
6.7\end{array}$ & $\begin{array}{r}200.9 \\
7.4\end{array}$ & $\begin{array}{r}254.7 \\
10.2\end{array}$ & $\begin{array}{r}121.6 \\
5.1\end{array}$ & $\begin{array}{l}207.4 \\
7.8\end{array}$ \\
\hline \multirow{2}{*}{\multicolumn{11}{|c|}{ Memorandum items (in millions of U.S. dollars) }} \\
\hline & & & & & & & & & & \\
\hline NPV o & 641.0 & 765.9 & 886.4 & 1030.5 & 1198.9 & 2230.0 & 4238.6 & 7888.7 & 1340.9 & $\begin{array}{l}4803 \\
4512\end{array}$ \\
\hline debt & 98.3 & 215.6 & 333.7 & 482.3 & 665.0 & & & & 845.8 & \\
\hline Deb & 36.0 & 18.0 & 20.7 & 34.9 & 50.1 & & 1 & & .9 & $\begin{array}{l}197 \\
166\end{array}$ \\
\hline throp var averag & 1.6 & 1.7 & $\begin{array}{r}4.6 \\
077\end{array}$ & 8.9 & 12.7 & 60.1 & 13 & 3 & 6 & $\begin{array}{r}166 \\
2245\end{array}$ \\
\hline ds and services, three year average & $\begin{array}{l}807.6 \\
8107\end{array}$ & $\begin{array}{l}836.9 \\
867.1\end{array}$ & $\begin{array}{l}872.1 \\
938.6\end{array}$ & 934.6 & $\begin{array}{l}1000.2 \\
10640\end{array}$ & $\begin{array}{l}1430.7 \\
15440\end{array}$ & $\begin{array}{l}2110.3 \\
22751\end{array}$ & $\begin{array}{l}3097.8 \\
3337.0\end{array}$ & $\begin{array}{l}1063.8 \\
1132.8\end{array}$ & $\begin{array}{l}2245.8 \\
2420.8\end{array}$ \\
\hline $\begin{array}{l}\text { Exports of goods and services } 3 / \\
\text { Government revenue }\end{array}$ & $\begin{array}{l}810.7 \\
6959\end{array}$ & $\begin{array}{l}867.1 \\
764.4\end{array}$ & $\begin{array}{l}938.6 \\
789.2\end{array}$ & $\begin{array}{l}998.1 \\
835.1\end{array}$ & $\begin{array}{r}1064.0 \\
890.6\end{array}$ & $\begin{array}{l}1544.0 \\
1213.7\end{array}$ & $\begin{array}{l}2275.1 \\
1680.8\end{array}$ & $\begin{array}{l}3337.0 \\
2218.3\end{array}$ & $\begin{array}{r}1132.8 \\
935.4\end{array}$ & $\begin{array}{l}2420.8 \\
1747.0\end{array}$ \\
\hline & & & & & & & & & & \\
\hline
\end{tabular}

Sources: Haitian authorities, and Bank-Fund staff estimates and projections.

1/ All debt indicators refer to public and publicly guaranteed debt after full delivery of debt relief (including debt relief beyond the HIPC Initiative and MDRI relief) 2/ Based on a three-year backward looking moving average of exports of goods and services.

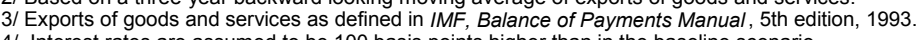

$5 /$ Exports are assumed to grow at 4.6 percent, an average reduction of about 2.5 percentage points compared to the baseline scenario.

6/ GDP growth is assumed to be 2.0 percentage points lower on average than in the baseline scenario. 
Table 10. Haiti: Delivery of IMF Assistance under the Enhanced HIPC Initiative, 2006/07 - 2016/17 1/ (In millions of SDRs, unless otherwise indicated)

\begin{tabular}{|c|c|c|c|c|c|c|c|c|c|c|c|c|}
\hline \multirow[b]{3}{*}{ I. Pre-MDRI Debt relief (under the HIPC Initiative only) 2I } & \multirow{2}{*}{\multicolumn{2}{|c|}{ 2006/07 2007/08 }} & \multicolumn{2}{|c|}{$2008 / 09$} & \multirow{2}{*}{\multicolumn{2}{|c|}{ 2009/10 2010/11 }} & \multirow{2}{*}{\multicolumn{2}{|c|}{$2011 / 122012 / 13$}} & \multirow[t]{2}{*}{ 2013/14 } & \multirow{2}{*}{\multicolumn{2}{|c|}{$2014 / 152015 / 16$}} & \multirow[t]{2}{*}{$2016 / 17$} \\
\hline & & & \multicolumn{2}{|c|}{ Oct.-Jun. Jul.-Sep. } & & & & & & & & \\
\hline & & & & & & & & & & & & \\
\hline HIPC-eligible debt service due on IMF obligations $3 /$ & 0.1 & 0.2 & 0.2 & - & 0.1 & 0.1 & 2.9 & 5.7 & 5.7 & 5.7 & 5.7 & 2.8 \\
\hline Principal & - & - & - & - & - & - & 2.8 & 5.6 & 5.6 & 5.6 & 5.6 & 2.8 \\
\hline PRGF interest & 0.1 & 0.2 & 0.2 & - & 0.1 & 0.1 & 0.1 & 0.1 & 0.1 & 0.1 & 0.03 & 0.01 \\
\hline HIPC assistance-deposits into the HIPC Umbrella Account & -- & -- & & & & & & & & & & \\
\hline Interim assistance & 0.042 & 0.107 & 0.140 & & & & & & & & & \\
\hline Completion point disbursement & & & 2.0 & & & & & & & & & \\
\hline Completion point assistance $4 /$ & & & 1.8 & & & & & & & & & \\
\hline Completion point interest & & & 0.2 & & & & & & & & & \\
\hline HIPC assistance-drawdown schedule from HIPC Umbrella Account & 0.04 & 0.1 & 0.1 & - & - & - & 0.3 & 0.4 & 0.4 & 0.4 & 0.4 & 0.5 \\
\hline IMF assistance without interest & 0.04 & 0.1 & 0.1 & - & - & - & 0.1 & 0.3 & 0.3 & 0.4 & 0.4 & 0.5 \\
\hline Estimated interest earnings 5 / & 0.0 & 0.0 & 0.0 & - & - & - & 0.2 & 0.1 & 0.1 & 0.0 & 0.0 & 0.0 \\
\hline Debt service due on IMF obligations after HIPC assistance & 0.04 & 0.1 & 0.1 & - & 0.1 & 0.1 & 2.7 & 5.3 & 5.3 & 5.3 & 5.3 & 2.3 \\
\hline basis) & 2.0 & 5.1 & 6.7 & - & - & - & 4.3 & 12.9 & 12.9 & 17.2 & 17.2 & 21.6 \\
\hline Share of debt service due on IMF obligations covered by HIPC assistance (in percent) & 51.5 & 56.7 & 58.8 & - & - & - & 8.8 & 6.9 & 6.8 & 7.0 & 6.8 & 16.6 \\
\hline $\begin{array}{l}\text { Proportion (in percent) of each repayment falling due during the period to be paid } \\
\text { by HIPC assistance from the principal deposited in Umbrella Account }\end{array}$ & 51.3 & 56.6 & 58.6 & - & - & - & 3.2 & 4.8 & 4.8 & 6.4 & 6.4 & 16.1 \\
\hline II. Post-MDRI Debt relief (under both MDRI and HIPC Initiatives) & & & 2.0 & & & & & & & & & \\
\hline Projected pre-cutoff date debt at completion point $6 /$ & & & - & & & & & & & & & \\
\hline Delivery of remaining HIPC assistance for post MDRI cutoff date debt (on stock basis): & & & 2.0 & & & & & & & & & \\
\hline III. Debt service due to the IMF after HIPC and MDRI debt relief 7 I & 0.04 & 0.1 & 0.1 & - & 0.4 & 0.4 & 1.2 & 8.3 & 16.2 & 18.6 & 18.5 & 15.6 \\
\hline
\end{tabular}

Source: Fund staff estimates and projections.

1/ Total IMF assistance under the enhanced HIPC Initiative is SDR 2.101 million in NPV terms calculated on the basis of data available at the decision point, excluding interest earned

on Haiti's account and on committed but undisbursed amounts as described in footnotes 5 . Fiscal years cover the period from October to September.

2/ Reflects the projected delivery of HIPC assistance in the absence of MDRI decision.

3/ Data prior to completion point represent actual debt service paid. Project debt service is as of decision point. Interest obligations exclude net SDR charges and assessments which are not eligible for HIPC assistance.

4/ A final disbursement of SDR 2 million will be deposited into Haiti's Umbrella Account at the completion point in June 2009.

5/ Includes estimated interest earnings on: (a) amounts held in Haiti's Umbrella Account; and (b) up to the completion point, amounts committed but not yet disbursed. The projected interest

earnings are estimated based on assumed interest rates which are gradually rising to 4.5 percent in 2014; actual interest earnings may be higher or lower.

6/ Associated with disbursements made prior to December 31, 2004

7/ Data prior to completion point represent actual debt service paid. Projected debt service from April 2009 are as of end-March 2009. 
Table 11. Haiti: Delivery of World Bank HIPC Assistance and MDRI, 2005/06 - 2044/45 /1

(In millions of U.S. dollars, unless otherwise indicated)

Actuals

Projections

Fiscal Years 2005/06 2006/07 2007/08 2009 2009 2009/10 2010/11 2011/12 2012/13 2013/14 2014/15 2015/16 2016/17 2017/18 2018/19 2019/20 2024/25 2029/30 2034/35 2039/40 2044/45 Oct.- Jul.-

\section{Relief under the Enhanced HIPC Initiative 1/}

World Bank Debt Service Before HIPC Relief

Principal

World Bank Debt Service After HIPC Relief

World Bank HIPC Assistance 2/

$\begin{array}{rrrrrrrrrrrrrrrrrrrrrrr}49.7 & 51.4 & 54.5 & 13.9 & 6.1 & 20.9 & 21.2 & 21.2 & 21.1 & 20.9 & 22.4 & 23.8 & 24.0 & 23.8 & 23.6 & 23.5 & 22.5 & 16.3 & 6.8 & 1.6 & 0.8 & 25.4 & 7.9 \\ 36.2 & 37.6 & 40.8 & 11.2 & 5.1 & 17.3 & 17.7 & 17.9 & 17.9 & 17.9 & 19.4 & 21.0 & 21.3 & 21.3 & 21.3 & 21.3 & 21.1 & 15.7 & 6.6 & 1.5 & 0.8 & 21.5 & 7.7 \\ 13.5 & 13.8 & 13.7 & 2.7 & 1.1 & 3.6 & 3.5 & 3.4 & 3.2 & 3.1 & 3.0 & 2.8 & 2.6 & 2.5 & 2.3 & 2.2 & 1.4 & 0.6 & 0.2 & 0.1 & 0.0 & 3.9 & 0.3 \\ 49.7 & 44.0 & 51.7 & 13.9 & 3.2 & 12.6 & 21.2 & 21.2 & 21.1 & 20.9 & 22.4 & 23.8 & 24.0 & 23.8 & 23.6 & 23.5 & 22.5 & 16.3 & 6.8 & 1.6 & 0.8 & 24.4 & 7.9 \\ 0.0 & 7.3 & 2.8 & 0.0 & 3.0 & 8.3 & 0.0 & 0.0 & 0.0 & 0.0 & 0.0 & 0.0 & 0.0 & 0.0 & 0.0 & 0.0 & 0.0 & 0.0 & 0.0 & 0.0 & 0.0 & 1.0 & 0.0\end{array}$

\section{Relief under the MDRI 3}

Projected Stock of IDA Credits Outstanding at Implementation Date 4/

Debt Stock Reduction on Eligible Credits 5/

Due to HIPC relief

Due to MDR

Remaining IDA Credits After HIPC and MDRI Relief

IDA Debt Service Relief Under the MDRI 7 |

Debt Service Due to IDA after HIPC Relief and the MDR

\section{Memorandum item:}

\section{HIPC relief}

Debt Service to IDA Covered by HIPC (in percent)

Debt Service to IDA Covered by HIPC and MDRI (in percent)

Interim Assistance 8/

Interim Assistance as Percent of Total HIPC Relief 8

IDA Debt Service Relief Under the MDRI (in millions of SDR) 9 /

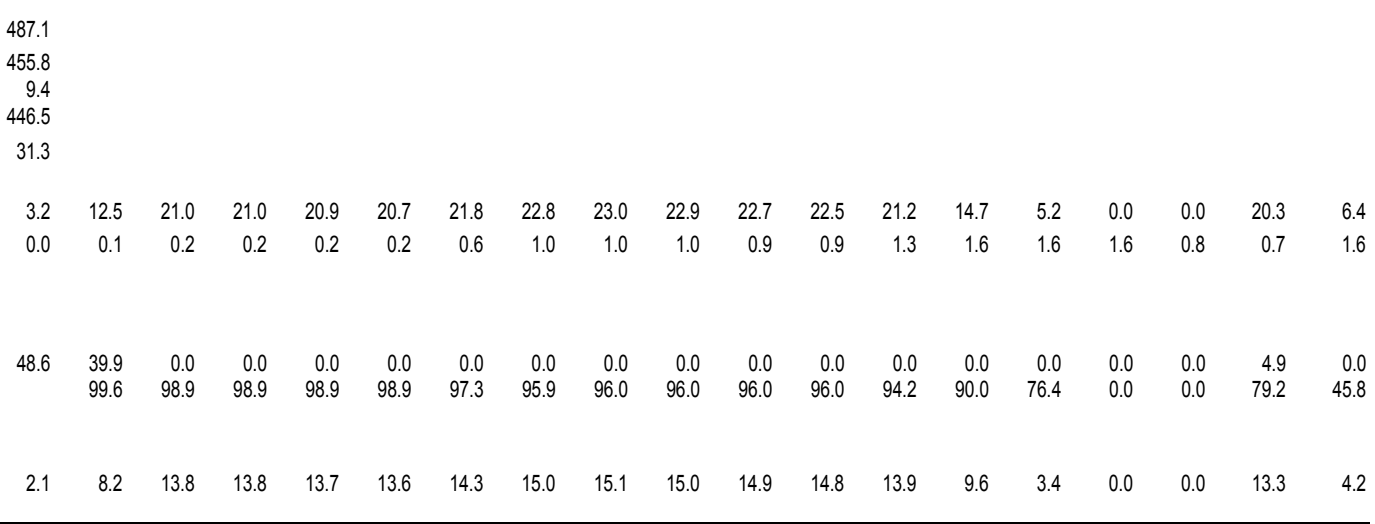

Source: IDA staff estimates.

1/ For the FY 2006-2008 period, debt service and debt relief is estimated on debt outstanding as of end-September 2005, using end-September 2005 exchange rates. For the projection period, the debt service presented here is on end-September 2008 outstanding debt, using end-September 2008 exchange rates.

2/ Enhanced HIPC assistance until end-June 2009 as approved by the Board of IDA (IDA/R2006-6026/1). After July 1, 2009, HIPC debt relief is based on revised schedule. Total HIPC debt relief amounts to US\$52.83 million in NPV terms, including a

(a)

5/ Debt disbused as of fond as of June 30,2009 .

(2008

$6 /$ HIPC relief is assumed to proportionally reduce repayments of principal and charges on IDA credits disbursed as of end-September 2005 and still outstanding as of end-September 2008.

$7 /$ Using end-September 2008 exchange rates.

9/ For SDR-denominated IDA credits, debt relief under the MDRI is estimated as 100 percent of SDR-based debt service minus USD-based debt relief under the Enhanced HIPC Initiative. HIPC debt relief is converted into SDR equivalent amounts by

applying the foreign exchange reference rate of 1.52448 agreed by donors under the latest regular IDA replenishment. For USD-denominated IDA credits. Debt relief under the MDRl is estimated as 100 percent of USD-based debt service minus

USD-based debt relief under the Enhanced HIPC Initiative. The resulting MDRI debt relief amounts are converted into SDR equivalent amounts by applying the foreign exchange reference rates agreed by donors under the latest regular IDA replenishment. 
Table 12. Paris Club Creditors' Delivery of Debt Relief Under Bilateral Initiatives Beyond the HIPC Initiative 1/

\begin{tabular}{|c|c|c|c|c|c|c|c|}
\hline Countrie & vered & ODA (in p & percent) & Non-ODA (in & cent) & Provision of $r$ & relief \\
\hline & & Pre-cutoff date debt $P$ & Post-cutoff date debt & Pre-cutoff date debt Po & utoff date debt & ision point & Completion \\
\hline & (1) & (2) & (3) & (4) & (5) & (6) & (7) \\
\hline Australia & HIPCs & 100 & 100 & 100 & 100 & & \\
\hline Austria & HIPCs & 100 & - & 100 & 0 & Case-by-case, flow & Stock \\
\hline Belgium & HIPCs & 100 & 100 & 100 & - & 100 flow & Stock \\
\hline Canada & HIPCs 21 & -31 & -31 & 100 & 100 & 100 flow & Stock \\
\hline Denmark & HIPCs & 100 & $1004 /$ & 100 & $1004 /$ & 100 flow & Stock \\
\hline France & HIPCs & 100 & 100 & 100 & - & 100 flow $5 /$ & Stock \\
\hline Finland & HIPCs & 100 & $-6 /$ & 100 & $-6 /$ & - & - \\
\hline Germany & HIPCs & 100 & 100 & 100 & 100 & 100 flow & Stock \\
\hline Ireland & - & - & - & - & - & - & - \\
\hline Italy & HIPCs & 100 & 10071 & 100 & 10071 & 100 flow & Stock \\
\hline Japan & HIPCs & 100 & 100 & 100 & - & - & Stock \\
\hline Netherlands & eHIPCs & $1008 /$ & 100 & 100 & - & $90-100$ flow 81 & Stock 81 \\
\hline Norway & HIPCs & 9/ & 9/ & $10 /$ & 101 & - & - \\
\hline Russia & HIPCS & $-11 /$ & $-11 /$ & 100 & 100 & - & Stock \\
\hline Spain & HIPCs & 100 & Case-by-case & 100 & Case-by-case & - & Stock \\
\hline Sweden & HIPCs & - & -121 & 100 & - & - & Stock \\
\hline Switzerland & HIPCs & $-13 /$ & $-13 /$ & $90-10014 /$ & - & 90-100 flow & Stock \\
\hline United King & HIPCS & 100 & 100 & 100 & $10015 /$ & 100 flow $15 /$ & Stock \\
\hline United Stat & HIPCs & 100 & 100 & 100 & $10016 /$ & 100 flow & Stock \\
\hline
\end{tabular}

Source: Paris Club Secretariat.

1/ Columns (1) to (7) describe the additional debt relief provided following a specific methodology under bilateral initiatives and need to be read as a whole for each creditor. In column (1), "HIPCs" stands for eligible countries effectively qualifying for the HIPC process. A "100 percent" mention in the table indicates that the debt relief provided under the enhanced HIPC Initiative framework will be topped up to 100 percent through a bilateral initiative.

2/ Canada: including Bangladesh. Canada has granted a moratorium of debt service as of January 2001 on all debt disbursed before end-March 1999 for 13 out of 17 HIPCs with debt service due to Canada. Eligible countries are Benin, Bolivia, Cameroon, Dem. Rep. Of Congo, Ethiopia, Ghana, Guyana, Honduras, Madagascar, Rwanda, Senegal, Tanzania, and Zambia. 100\% cancellation will be granted at completion point. As of July 2004, Canada has provided completion point stock of debt cancellation for Benin, Bolivia, Guyana, Senegal and Tanzania.

3/ 100 percent of ODA claims have already been cancelled on HIPCs, with the exception of Myanmar's debt to Canada.

4/ Denmark provides 100 percent cancellation of ODA loans and non-ODA credits contracted and disbursed before September 27, 1999.

5/ France: cancellation of 100 percent of debt service on pre-cutoff date commercial claims on the government as they fall due starting at the decision point. Once countries have reached their completion point, debt relief on ODA claims on the government will go to a special account and will be used for specific development projects.

6/ Finland: no post-COD claims

71 Italy: cancellation of 100 percent of all debts (pre- and post-cutoff date, ODA and non-ODA) incurred before June 20, 1999 (the Cologne Summit). At decision point, cancellation of the related amounts falling due in the interim period. At completion point, cancellation of the stock of remaining debt.

8/ The Netherlands: 100 percent ODA (pre- and post-cutoff date debt will be cancelled at decision point); for non-ODA: in some particular cases (Benin, Bolivia, Burkina Faso, Ethiopia, Ghana, Mali, Mozambique, Nicaragua, Rwanda, Tanzania, Uganda and Zambia), the Netherlands will write off 100 percent of the consolidated amounts on the flow at decision point; all other HIPCs will receive interim relief up to 90 percent reduction of the consolidated amounts. At completion point, all HIPCs will receive 100 per cent cancellation of the remaining stock of the pre-cutoff date debt.

9/ Norway has cancelled all ODA claims.

10/ Due to the current World Bank/IMF methodology for recalculating debt reduction needs at HIPC completion point, Norway has postponed the decisions on whether or not to grant $100 \%$ debt reduction until after the completion point.

11/ Russia has no ODA claims

12/ Sweden has no ODA claims.

13/ Switzerland has cancelled all ODA claims.

14/ In some particular cases (Central African Republic, Liberia, Republic of Congo, Sierra Leone, Togo), Switzerland will write off 100 percent of the remaining debt stock at completion point; all other HIPCs will receive debt relief according to Paris Club terms.

15/ United Kingdom: "beyond 100 percent" full write-off of all debts of HIPCs as of their decision points, and reimbursement at the decision point of any debt service paid before the decision point.

16/ United States: 100 percent post-cutoff date non-ODA treated on debt assumed prior to June 20, 1999 (the Cologne Summit). 
Table 13. HIPC Initiative: Status of Country Cases Considered Under the Initiative, March 31, 2009

\begin{tabular}{|c|c|c|c|c|c|c|c|c|c|c|c|}
\hline \multirow[b]{3}{*}{ Country } & \multirow{3}{*}{$\begin{array}{r}\text { Decision } \\
\text { Point }\end{array}$} & \multicolumn{3}{|c|}{$\begin{array}{c}\text { Target } \\
\text { NPV of Debt-to- }\end{array}$} & \multirow{2}{*}{\multicolumn{5}{|c|}{$\begin{array}{c}\text { Assistance Levels 1/ } \\
\text { (In millions of U.S. dollars, present value) }\end{array}$}} & \multirow{3}{*}{$\begin{array}{r}\text { Percentage } \\
\text { Reduction } \\
\text { in NPV of } \\
\text { Debt 2/ } \\
\end{array}$} & \multirow{3}{*}{$\begin{array}{c}\text { Estimated Total } \\
\text { Nominal Debt } \\
\text { Service Relief } \\
\text { (In millions of } \\
\text { U.S. dollars) }\end{array}$} \\
\hline & & \multirow{2}{*}{$\begin{array}{r}\text { Completion } \\
\text { Point }\end{array}$} & \multirow[b]{2}{*}{ Exports } & \multirow{2}{*}{$\begin{array}{r}\text { Gov. } \\
\text { revenue } \\
\text { nt) }\end{array}$} & & & & & & & \\
\hline & & & & & Total & $\begin{array}{l}\text { Bilateral and } \\
\text { commercial }\end{array}$ & \multicolumn{3}{|c|}{ Multilateral } & & \\
\hline Completion point reached un & hanced fra & lework (24) & & & & & & & & & \\
\hline Benin & Jul. 00 & Mar. 03 & 150 & & 265 & 77 & 189 & 24 & 84 & 31 & 460 \\
\hline Bolivia & & & & & 1,302 & 425 & 876 & 84 & 194 & & 2,060 \\
\hline original framework & Sep. 97 & Sep. 98 & 225 & & 448 & 157 & 291 & 29 & 54 & 14 & 760 \\
\hline enhanced framework & Feb. 00 & Jun. 01 & 150 & & 854 & 268 & 585 & 55 & 140 & 30 & 1,300 \\
\hline Burkina Faso & & & & & 553 & 83 & 469 & 57 & 231 & & 930 \\
\hline original framework & Sep. 97 & Jul. 00 & 205 & & 229 & 32 & 196 & 22 & 91 & 27 & 400 \\
\hline enhanced framework & Jul. 00 & Apr. 02 & 150 & & 195 & 35 & 161 & 22 & 79 & 30 & 300 \\
\hline topping-up & $\ldots$ & Apr. 02 & 150 & & 129 & 16 & 112 & 14 & 61 & 24 & 230 \\
\hline Burundi & Aug. 05 & Jan. 09 & 150 & & 833 & 127 & 706 & 28 & 425 & 92 & 1,366 \\
\hline Cameroon & Oct. 00 & Apr. 06 & 150 & & 1,267 & 879 & 322 & 37 & 176 & 27 & 4,917 \\
\hline Ethiopia & & & & & 1,982 & 637 & 1,315 & 60 & 832 & & 3,275 \\
\hline enhanced framework & Nov. 01 & Apr. 04 & 150 & & 1,275 & 482 & 763 & 34 & 463 & 47 & 1,941 \\
\hline topping-up & & Apr. 04 & 150 & & 707 & 155 & 552 & 26 & 369 & 31 & 1,334 \\
\hline Gambia, The & Dec. 00 & Dec. 07 & 150 & & 67 & 17 & 49 & 2 & 22 & 27 & 112 \\
\hline Ghana & Feb. 02 & Jul. 04 & 144 & 250 & 2,186 & 1,084 & 1,102 & 112 & 781 & 56 & 3,500 \\
\hline Guyana & & & & & 591 & 223 & 367 & 75 & 68 & & 1,354 \\
\hline original framework & Dec. 97 & May 99 & 107 & 280 & 256 & 91 & 165 & 35 & 27 & 24 & 634 \\
\hline enhanced framework & Nov. 00 & Dec-03 & 150 & 250 & 335 & 132 & 202 & 40 & 41 & 40 & 719 \\
\hline Honduras & Jul. 00 & Mar-05 & 110 & 250 & 556 & 215 & 340 & 30 & 98 & 18 & 1,000 \\
\hline Madagascar & Dec. 00 & Oct-04 & 150 & & 836 & 474 & 362 & 19 & 252 & 40 & 1,900 \\
\hline Malawi & & & & & 1,057 & 171 & 886 & 45 & 622 & & 1,628 \\
\hline enhanced framework & Dec. 00 & Aug-06 & 150 & & 646 & 164 & 482 & 30 & 333 & 44 & 1,025 \\
\hline topping-up & $\ldots$ & Aug-06 & 150 & & 411 & 7 & 404 & 15 & 289 & 35 & 603 \\
\hline Mali & & & & & 539 & 169 & 370 & 59 & 185 & & 895 \\
\hline original framework & Sep. 98 & Sep. 00 & 200 & & 121 & 37 & 84 & 14 & 43 & 9 & 220 \\
\hline enhanced framework & Sep. 00 & Mar. 03 & 150 & & 417 & 132 & 285 & 45 & 143 & 29 & 675 \\
\hline Mauritania & Feb. 00 & Jun. 02 & 137 & 250 & 622 & 261 & 361 & 47 & 100 & 50 & 1,100 \\
\hline Mozambique & & & & & 2,023 & 1,270 & 753 & 143 & 443 & & 4,300 \\
\hline original framework & Apr. 98 & Jun. 99 & 200 & & 1,717 & 1,076 & 641 & 125 & 381 & 63 & 3,700 \\
\hline enhanced framework & Apr. 00 & Sep. 01 & 150 & & 306 & 194 & 112 & 18 & 62 & 27 & 600 \\
\hline Nicaragua & Dec. 00 & Jan. 04 & 150 & & 3,308 & 2,175 & 1,134 & 82 & 191 & 73 & 4,500 \\
\hline Niger & & & & & 663 & 235 & 428 & 42 & 240 & & 1,190 \\
\hline enhanced framework & Dec. 00 & Apr. 04 & 150 & & 521 & 211 & 309 & 28 & 170 & 53 & 944 \\
\hline topping-up & $\ldots$ & Apr. 04 & 150 & & 143 & 23 & 119 & 14 & 70 & 25 & 246 \\
\hline Rwanda & & & & & 696 & 65 & 631 & 63 & 383 & & 1,316 \\
\hline enhanced framework & Dec. 00 & Apr-05 & 150 & & 452 & 56 & 397 & 44 & 228 & 71 & 839 \\
\hline topping-up & $\ldots$ & Apr-05 & 150 & & 243 & 9 & 235 & 20 & 154 & 53 & 477 \\
\hline São Tomé and Príncipe & & & & & 124 & 31 & 93 & 1 & 47 & 128 & 263 \\
\hline enhanced framework & Dec. 00 & Mar-07 & 150 & & 99 & 29 & 70 & - & 24 & 83 & 215 \\
\hline topping-up & $\ldots$ & Mar-07 & 150 & & 25 & 2 & 23 & 1 & 23 & 45 & 49 \\
\hline Senegal & Jun. 00 & Apr. 04 & 133 & 250 & 488 & 212 & 276 & 45 & 124 & 19 & 850 \\
\hline Sierra Leone & Mar. 02 & Dec. 06 & 150 & & 675 & 335 & 340 & 125 & 123 & 81 & 994 \\
\hline Tanzania & Apr. 00 & Nov. 01 & 150 & & 2,026 & 1,006 & 1,020 & 120 & 695 & 54 & 3,000 \\
\hline Uganda & & & & & 1,003 & 183 & 820 & 160 & 517 & & 1,950 \\
\hline original framework & Apr. 97 & Apr. 98 & 202 & & 347 & 73 & 274 & 69 & 160 & 20 & 650 \\
\hline enhanced framework & Feb. 00 & May 00 & 150 & & 656 & 110 & 546 & 91 & 357 & 37 & 1,300 \\
\hline Zambia & Dec. 00 & Apr-05 & 150 & & 2,499 & 1,168 & 1,331 & 602 & 493 & 63 & 3,900 \\
\hline Decision point reached under & 1ced frame & ork (11) & & & & & & & & & \\
\hline Afghanistan & Jul. 07 & Floating & 150 & & 571 & 436 & 135 & - & 75 & 51 & 1,272 \\
\hline Central African Rep. & Sept. 07 & Floating & 150 & & 583 & 217 & 365 & 27 & 209 & 68 & 782 \\
\hline Chad & May. 01 & Floating & 150 & & 170 & 35 & 134 & 18 & 68 & 30 & 260 \\
\hline Cote d'Ivoire & Mar. 09 & Floating & 250 & 250 & 3,005 & 2,311 & 694 & 38 & 402 & 24 & 3,129 \\
\hline Congo, Democratic Rep. of & Jul. 03 & Floating & 150 & & 6,311 & 3,837 & 2,474 & 472 & 831 & 80 & 10,389 \\
\hline Congo Rep. of & Mar. 06 & Floating & & 250 & 1,679 & 1,561 & 118 & 8 & 49 & 32 & 2,881 \\
\hline Guinea & Dec. 00 & Floating & 150 & & 545 & 215 & 328 & 31 & 152 & 32 & 800 \\
\hline Guinea-Bissau & Dec. 00 & Floating & 150 & & 416 & 212 & 204 & 12 & 93 & 85 & 790 \\
\hline Haiti & Nov. 06 & Floating & 150 & & 140 & 20 & 120 & 3 & 53 & 15 & 213 \\
\hline Liberia & Mar. 08 & Floating & 150 & & 2,846 & 1,420 & 1,426 & 732 & 375 & 91 & 4,008 \\
\hline $\begin{array}{l}\text { Togo } \\
\text { Total assistance provided/cor }\end{array}$ & dov. 08 & Floating & & 250 & $\begin{array}{r}270 \\
42,695\end{array}$ & $\begin{array}{r}120 \\
21,907\end{array}$ & $\begin{array}{r}150 \\
20,689\end{array}$ & $\begin{array}{r}0.3 \\
3,407\end{array}$ & $\begin{array}{r}98 \\
9,731\end{array}$ & 19 & $\begin{array}{r}360 \\
71,642\end{array}$ \\
\hline
\end{tabular}

Sources: IMF and World Bank Board decisions, completion point documents, decision point documents, preliminary HIPC documents, and staff calculations.

1/ Assistance levels are at countries' respective decision or completion points, as applicable.

2/ In percent of the net present value of debt at the decision or completion point (as applicable), after the full use of traditional debt-relief mechanisms.

3/ Equivalent to SDR 1,698 million at an SDR/USD exchange rate of 0.644524 , as of October 4, 2007. 


\section{APPENDIX I - DEBT MANAGEMENT}

1. Debt management in Haiti has improved since the decision point was reached in November 2006. At the decision point, several issues were identified as priorities for reform in the area of debt management and debt recording and reporting. Two such issues have also been included as the basis for HIPC completion point triggers (see Box 1).

2. In the area of debt recording, the BRH and MEF recently completed the installation of the most recent version of the UNCTAD DMFAS system, version 5.3, with the help of UNCTAD consultants. While DMFAS version 5.2 had previously been installed, the authorities had relied primarily on a Microsoft Excel database system for debt recording. The upgraded DMFAS system allows for all domestic and foreign currency-denominated debt data to be centralized into a single database, and networked so that it is available to both the BRH and MEF simultaneously.

\section{The new software will ensure secure access to the system and real-time backups}

between the BRH and MEF, which will facilitate improvements in the availability, quality, and security of debt data. The staffs of both institutions have received extensive training from UNCTAD in the use of the updated software. The completeness and accuracy of the new database through end-September 2008 was also verified as part of the completion point debt data reconciliation, with only minor errors that the authorities have committed to rectifying.

\section{Debt reporting by the government has also improved, resulting in part from the} upgrade to the latest DMFAS system. Debt reporting by the BRH has focused on the preparation of monthly, quarterly, and annual reports covering external debt service, the accumulation of arrears, disbursements, new borrowings, and the evolution of the debt stock. Such reports have been circulated within the government to support policymaking and planning, while some of this information was eventually made public after a considerable lag. The authorities have focused on improving debt reporting over the past several years, and the newly centralized database and updated software has helped them to produce and publish detailed quarterly reports that reflect recent debt data (with a three-month lag) in March and June 2009, with the objective of continuing to produce and publish such bulletins in the future.

5. From an institutional perspective, the improved debt management capacity and the use of a new debt recording system will support the transfer of some functions related to debt recording, reporting, and analysis from the BRH to the MEF. Debt management functions and responsibilities are currently shared between the BRH and MEF, with the BRH maintaining primary responsibility for debt data recording and reporting, and the MEF broadly in charge of front office functions and the authorization of debt service payments by the BRH in its capacity as the government's fiscal agent. With the newly-installed system, the MEF intends to take over the data-entry responsibilities for external debt, and to take the lead in producing and publishing periodic debt data reports. Access to a complete database would also facilitate the MEF's front and middle office functions with respect to debt management, which should ideally 
include the development of regular borrowing strategies and plans, negotiating external loan agreements with creditors, and the analysis of costs and risks associated with new borrowing. The authorities are working with the Center for Latin American Monetary Studies (CEMLA) to address these issues.

\section{As noted in the decision point document, the overall debt management legal and} institutional framework needs to be enhanced. In particular, the BRH and the MEF's specific responsibilities for debt management functions need to be further clarified and enshrined in legislation, coordination and information sharing between the two institutions should be improved, and analytical capacity with respect to the preparation of annual debt management strategies and related technical analysis must be developed. These and the above-mentioned reforms are being considered in the context of the ongoing project with CEMLA. 


\section{ApPendix II - DebT Sustainability Analysis (LIC DSF Methodology)}

June 2009

The debt sustainability analysis (DSA) was prepared jointly by Bank and Fund staffs in accordance with the standardized Debt Sustainability Framework (DSF) methodology for lowincome countries (LICs). The DSA has also benefited from consultations with Inter-American Development Bank staff. Although HIPC and MDRI relief would substantially reduce Haiti's debt burden, the DSA findings indicate the risk of external debt distress is still high given a present value $(P V)$ of debt-to-exports ratio that is above the relevant policy-dependent threshold in the baseline scenario and higher in alternative and shocks scenarios. ${ }^{1}$ Haiti's weak export base is a key factor in its risk of debt distress, as noted in the previous DSA. ${ }^{2}$

\section{Background}

\section{Haiti's public debt as of end-September 2008 is estimated at about 36 percent of}

GDP. Most of the debt is owed to external creditors (28 percent of GDP), mainly the Inter-American Development Bank (41 percent of total external debt), the World Bank (27 percent), and bilateral creditors (24 percent). Domestic public debt corresponds to credit to the government from the central bank $(\mathrm{BRH})$ and Treasury bill issuance in the coming years. This DSA's coverage of domestic debt of the central government, including borrowing by the government from the BRH but excluding bonds issues by the BRH, differs from the last DSA's coverage of domestic debt, which included only BRH bonds and not central government borrowing from the $\mathrm{BRH}$ (BRH bonds have been issued for monetary purposes). The change in coverage of domestic debt helps explain the higher level of total public debt (36 percent of GDP in 2008 compared to 29 percent of GDP in the previous DSA).

\section{As detailed in the completion point document, Haiti will benefit from irrevocable} HIPC and MDRI debt relief upon reaching its HIPC completion point. The nominal reduction in Haiti's debt stock is estimated to be $\$ 1.1$ billion with annual debt service savings of more than $\$ 50$ million for the first ten years following completion point.

3. Haiti has taken steps to strengthen its debt management capacity. With the help of UNCTAD and the World Bank, Haiti has created a single external debt database that will facilitate information sharing between the finance ministry and central bank, and has begun

\footnotetext{
${ }^{1}$ Haiti is classified as a weak performer based on its three-year average score of 2.83 on the World Bank's Country Policy and Institutional Assessment index (CPIA). For a weak performer (defined as those with three-year average CPIA ratings below 3.25), the indicative thresholds for external debt sustainability are a PV of debt-to-GDP ratio of 30 percent, a PV of debt-to-exports ratio of 100 percent, a PV of debt-to-revenue ratio of 200 percent, a debtservice-to-exports ratio of 15 percent, and a debt service-to-revenue ratio of 25 percent.
}

${ }^{2}$ IMF Country Report No. 09/77 
publishing quarterly external debt reports. In addition, as part of the HIPC Capacity Building Program, Haiti is working with the Center for Latin American Monetary Studies (CEMLA) to enhance its debt management capacity.

\section{Assumptions}

4. The medium-term assumptions for the DSA have been revised somewhat to reflect developments since the February 2009 DSA update. Macroeconomic assumptions are detailed in Box A1 and Table A1. The February DSA update incorporated the effects of the 2008 hurricanes and tropical storms, as well as initial estimates for the financial crisis impact. In this DSA, long-term assumptions are largely similar to those used in February, but some adjustments have been made to near-term forecasts. In particular, the effects of the global financial crisis have intensified in recent months, and accordingly the near-term growth and revenue forecasts have been lowered, as has the forecast for the GDP deflator due to the steep fall in commodity prices.

5. The baseline scenario in the DSA assumes delivery of HIPC and MDRI relief. Unlike the last DSA, which showed the impact of HIPC and MDRI relief as an alternative scenario, the baseline now reflects the assumption that completion point is reached by end-June 2009. The HIPC data reconciliation exercise has also strengthened the quality of the underlying debt stock and service data used in the DSA.

\section{The DSA assumes future PetroCaribe-related flows do not contribute to public}

debt. $^{3}$ Beyond the approximately $\$ 197$ million transferred in late 2008 and early 2009 , PetroCaribe flows are not treated as public debt-creating since it is expected that such amounts will be liabilities of a private bi-national corporation rather than the government.

\footnotetext{
${ }^{3}$ Under the PetroCaribe agreement, Haiti receives concessional financing for a portion of its oil imports from the República Bolivariana de Venezuela.
} 


\section{Box A1. Macroeconomic Assumptions}

Growth and inflation: GDP is assumed to be lower than in the previous DSA in FY 2009 (now projected to be 2.0 percent versus 2.5 percent previously) due to slower global growth, while in the medium-term the real rate of growth is assumed to converge to 4.5 percent, as in the previous DSA. Prices are projected to fall more quickly than assumed in the last DSA. The GDP deflator is assumed to be about 6 percent in 2009 (compared to 12 percent previously) and would reach 5 percent over the medium-term.

Fiscal policy: After an initial deterioration in the overall fiscal deficit including grants to 4.7 percent of GDP in FY 2009, reflecting large near-term spending needs as well as the negative impact of the global slowdown on revenue, the after-grants deficit would fall to 2.3 percent of GDP over the long-run. The improvement in the fiscal deficit reflects an improvement in revenue collection to just above 15 percent of GDP in the long-term (comparable to the level in the last DSA), although the improvement in the deficit is smaller than assumed at the time of the last DSA due to somewhat higher primary spending (19.7 percent of GDP by the end of the period compared to 18.1 percent of GDP previously).

Grants and financing: Grants are expected to increase substantially in FY 2009 and somewhat in FY 2010, reflecting hurricane reconstruction needs and additional pledges of support from the recent donors' conference. Thereafter, a conservative approach is taken with the U.S. dollar value of grants only assumed to grow by 2 percent annually in the long-term, implying an increase in the share of the deficit covered by borrowing. Plans to begin Treasury bill issuance in 2010 mean some financing needs can be covered domestically without recourse to BRH or external financing, but the DSA assumes only 0.6 percent of GDP in domestic financing in the long-term.

Current account: Exports of goods and services in U.S. dollar terms are expected to fall in FY 2009 by 2.7 percent, somewhat less than the 4.3 percent decline expected at the time of the last DSA. Over the long-term, exports would grow at about 8 percent annually (compared to 7.6 percent in the last DSA) to reach about 16 percent of GDP by 2029 (compared to 14.4 percent of GDP by 2028 in the last DSA). Long-term export growth would be supported by planned infrastructure improvements as well as the Hemispheric Opportunity and Partnership Encouragement (HOPE) initiative, which provides preferential access to the U.S. market. Imports of goods and services would fall slightly in 2009 (by about 0.3 percent) as somewhat lower food and fuel prices offset substantial reconstruction needs. Import growth would pick up to 6.2 percent annually over the long term (compared to 5.7 percent in the last DSA) with imports reaching 37.6 percent of GDP in 2029 (compared to 36 percent of GDP in the last DSA). The non-interest current account deficit would be 2.3 percent of GDP by the end of the period, or about $1 / 2$ percent of GDP higher than the previous DSA. Remittances have been less affected by the international financial crisis than previously expected, and are now forecast to fall to 18.7 percent of GDP in FY 2009 (compared to 16 percent of GDP in the previous DSA and 19.7 percent of GDP in FY 2008). 


\section{External Debt Sustainability}

7. Haiti's external debt relative to exports remains high in the baseline scenario (see Figure A1 and Tables A2 and A3 for the evolution of external debt ratios under the baseline and alternative/shock scenarios). The updated macroeconomic framework and in particular the drop in revenue in FY 2009 due to the international financial crisis worsen somewhat the expected path of Haiti's debt ratios compared with the alternative post-debt relief scenario in the previous DSA. Plans to pay down debt to the BRH also increase external borrowing needs through the medium-term. The PV of external debt-to-exports ratio will increase in the medium-term, just breaching the 100 percent threshold in FY 2014 and FY 2015. The ratio declines subsequently as the impact of the HOPE initiative on export growth kicks in, but remains near the 100 percent threshold throughout the projection period, reflecting Haiti's weak export base, substantial needs, and limited debt-carrying capacity. In the baseline scenario, other debt stock and debt service ratios remain well below the relevant thresholds throughout the projection period.

\section{Based on the sensitivity analysis, Haiti's debt-to-exports ratio could deteriorate} significantly in the event of shocks. Although the alternative and shock scenarios would worsen all of Haiti's debt stock and service indicators, the ratios would only exceed the indicative threshold in the case of the PV of debt-to-exports ratio. For the PV of debt-to-exports, Haiti is most vulnerable to a combined shock to growth, exports, prices, and non-debt creating flows, but is also susceptible to lower non-debt-creating flows such as grants and remittances, less favorable borrowing terms, and weaker export growth. In each of these four alternative or shock scenarios, the PV of debt-to-exports would rise substantially (to 168 percent for the combined shock) before declining, but would remain above the indicative threshold for the entire projection period. The alternative scenario based on historical values for key variables shows lower debt ratios primarily due to a smaller current account deficit than in the baseline scenario, which in turn reflects low levels of external financing in the past during periods of social and political conflict

\section{Public Debt Sustainability}

9. In the baseline scenario, public debt indicators rise somewhat during the projection period (see Figure A2 and Tables A4 and A5 for the evolution of public debt ratios under the baseline and alternative/shock scenarios). The PV of debt-to-GDP ratio rises from 17 percent in FY 2009 to 21.5 percent of GDP by FY 2029, reflecting primarily an increase in external debt over the period. The PV of debt-to-revenue ratio has a similar profile, rising from about 99 percent in FY 2009 to about 119 percent in FY 2029. Debt service-to-revenue rises from about 6 percent in FY 2009 to a high of 7.7 percent in FY 2016 before dropping back to about 7 percent by FY 2029. 
10. Alternative and shock scenarios put public debt on a more sharply rising trajectory during the projection period. Instead of rising only gradually as under the baseline scenario, if the primary deficit is fixed at its relatively high FY 2009 level, the PV of public debt-to-GDP ratio would grow to 41 percent in FY 2029 from 17 percent in FY 2009, while the PV of public debt-to-revenue ratio would reach 225 percent in FY 2029 compared to 99 percent in FY 2009. Keeping the primary balance unchanged at the FY 2009 level would also raise debt service-torevenue from 6 percent in FY 2009 to 13 percent in FY 2029. Using historical values or the most extreme shock (growth for the debt stock indicators and lower non-debt-creating flows for the debt service measure) would also raise debt above the baseline scenario, although the deterioration would be less pronounced than seen when holding the FY 2009 primary balance constant.

\section{Conclusions}

\section{Haiti's risk of external debt distress remains high given a PV of debt-to-exports} ratio above the indicative threshold in the baseline scenario. Alternative and shock scenarios highlight additional risks on the PV of debt-to-exports, while other debt stock and service indicators remain below the relevant thresholds in all scenarios. In terms of public debt, there is a risk of steadily rising debt ratios under alternative and shock scenarios, particularly if the primary balance is fixed at the FY 2009 level.

\section{Further steps are needed to safeguard debt sustainability following HIPC and}

MDRI relief. HIPC/MDRI relief bring the PV of debt-to-exports ratio below the relevant indicative threshold in FY 2009, but the ratio reaches the threshold by FY 2014, and would be much worse in the likely event of future shocks. Securing lasting debt sustainability will depend on: maximizing grant assistance; a prudent borrowing strategy, for which efforts to strengthen debt management should help; and steps to enhance Haiti's small export base, including through improved security and infrastructure to boost trade, especially given preferential opportunities. Better security and infrastructure could catalyze higher foreign direct investment flows. Greater resilience to natural disasters would also help. Finally, sustained reform progress to bolster institutions and policy implementation capacity would increase Haiti's ability to handle a higher level of debt. 
Table A1. Haiti: Long-Term Macroeconomic Assumptions, FY 2009-2029

\begin{tabular}{|c|c|c|c|c|c|c|c|c|c|c|}
\hline & \multirow[b]{2}{*}{2009} & \multirow[b]{2}{*}{2010} & \multirow[b]{2}{*}{2011} & \multirow[b]{2}{*}{2012} & \multirow[b]{2}{*}{2013} & \multirow[b]{2}{*}{2014} & \multirow[b]{2}{*}{2019} & \multirow[b]{2}{*}{2029} & \multicolumn{2}{|c|}{ Averages } \\
\hline & & & & & & & & & 2009-18 & 2019-29 \\
\hline & \multicolumn{8}{|c|}{ (Annual percentage change) } & & \\
\hline \multicolumn{11}{|l|}{ National income and prices } \\
\hline GDP at constant prices & 2.0 & 2.4 & 3.2 & 3.3 & 3.4 & 3.7 & 4.5 & 4.5 & 3.5 & 4.5 \\
\hline GDP deflator & 6.3 & 8.3 & 5.5 & 5.2 & 5.2 & 5.2 & 5.0 & 5.0 & 5.6 & 5.0 \\
\hline Real GDP per capita (local currency) & 0.3 & 0.7 & 1.6 & 1.7 & 1.8 & 2.1 & 3.0 & 3.2 & 1.9 & 3.1 \\
\hline Consumer prices (period average) & 5.1 & 7.7 & 5.0 & 5.0 & 5.0 & 5.0 & 5.0 & 5.0 & 5.3 & 5.0 \\
\hline \multicolumn{11}{|l|}{ External sector (value in USD) } \\
\hline Exports of goods and non-factor services & -2.7 & 7.0 & 8.2 & 6.3 & 6.6 & 6.6 & 8.1 & 7.9 & 6.4 & 8.0 \\
\hline Imports of goods and non-factor services & -0.3 & 4.3 & 3.3 & 3.1 & 4.4 & 4.8 & 6.2 & 6.2 & 4.4 & 6.2 \\
\hline \multicolumn{11}{|l|}{ Central government (value in Gourdes) } \\
\hline Total revenue and grants & 29.4 & 19.9 & 0.1 & 9.8 & 10.0 & 10.1 & 10.4 & 9.0 & 11.8 & 10.1 \\
\hline Central government revenue $1 /$ & 8.2 & 20.3 & 10.8 & 11.9 & 12.3 & 12.4 & 12.2 & 9.7 & 12.2 & 11.4 \\
\hline Central government primary expenditure & 37.7 & 8.8 & 0.1 & 11.2 & 10.5 & 9.3 & 9.7 & 9.2 & 11.4 & 9.9 \\
\hline \multicolumn{11}{|c|}{ (In percent of GDP, unless otherwise indicated) } \\
\hline \multicolumn{11}{|l|}{ National income } \\
\hline Nominal GDP (Gourdes, billions) & 288 & 319 & 348 & 378 & 411 & 448 & 709 & 1,793 & 445 & 1,176 \\
\hline Nominal GDP (USD billions) & 7.0 & 7.3 & 7.5 & 7.9 & 8.3 & 8.8 & 12.0 & 22.6 & 8.8 & 16.8 \\
\hline GDP per capita (US dollars) & 710 & 721 & 734 & 757 & 785 & 818 & 1,037 & 1,716 & 820 & 1,349 \\
\hline \multicolumn{11}{|l|}{ External sector } \\
\hline Non-interest current account deficit 2/, 3/ & -2.9 & -3.0 & -3.1 & -2.9 & -2.7 & -2.7 & -2.8 & -2.3 & -2.8 & -2.6 \\
\hline Exports of goods and non-factor services & 11.5 & 11.9 & 12.5 & 12.7 & 12.8 & 12.9 & 13.9 & 15.9 & 12.8 & 14.9 \\
\hline Imports of goods and non-factor services & 40.7 & 41.1 & 41.0 & 40.3 & 40.0 & 39.6 & 38.9 & 37.6 & 39.9 & 38.3 \\
\hline External current account balance $1 /$ & -12.4 & -12.0 & -10.5 & -9.6 & -9.2 & -9.0 & -8.2 & -6.0 & -9.8 & -7.1 \\
\hline External current account balance 2/ & -3.0 & -3.0 & -2.8 & -2.4 & -2.2 & -2.2 & -2.7 & -2.3 & -2.6 & -2.6 \\
\hline Liquid gross reserves (in months of imports of G\&S) & 3.0 & 3.0 & 2.8 & 2.9 & 3.0 & 3.2 & 3.0 & 2.7 & 3.0 & 2.9 \\
\hline \multicolumn{11}{|l|}{ Central government } \\
\hline Central government overall balance $2 /$ & -4.7 & -2.7 & -2.6 & -2.9 & -3.1 & -3.1 & -2.3 & -2.3 & -3.0 & -2.3 \\
\hline Total revenue and grants & 17.0 & 18.4 & 16.9 & 17.1 & 17.3 & 17.5 & 17.7 & 18.2 & 17.4 & 18.1 \\
\hline Central government revenue $1 /$ & 10.1 & 10.9 & 11.1 & 11.5 & 11.8 & 12.2 & 13.4 & 15.4 & 11.9 & 14.7 \\
\hline Central government primary expenditure & 20.9 & 20.5 & 18.9 & 19.3 & 19.6 & 19.7 & 19.3 & 19.7 & 19.7 & 19.6 \\
\hline
\end{tabular}

1/ Excluding grants

2/ Including grants

3/ Includes interest earned on foreign exchange reserves. 
Figure A1. Haiti: Indicators of Public and Publicly Guaranteed External Debt under Alternatives Scenarios, 2009-2029 1/
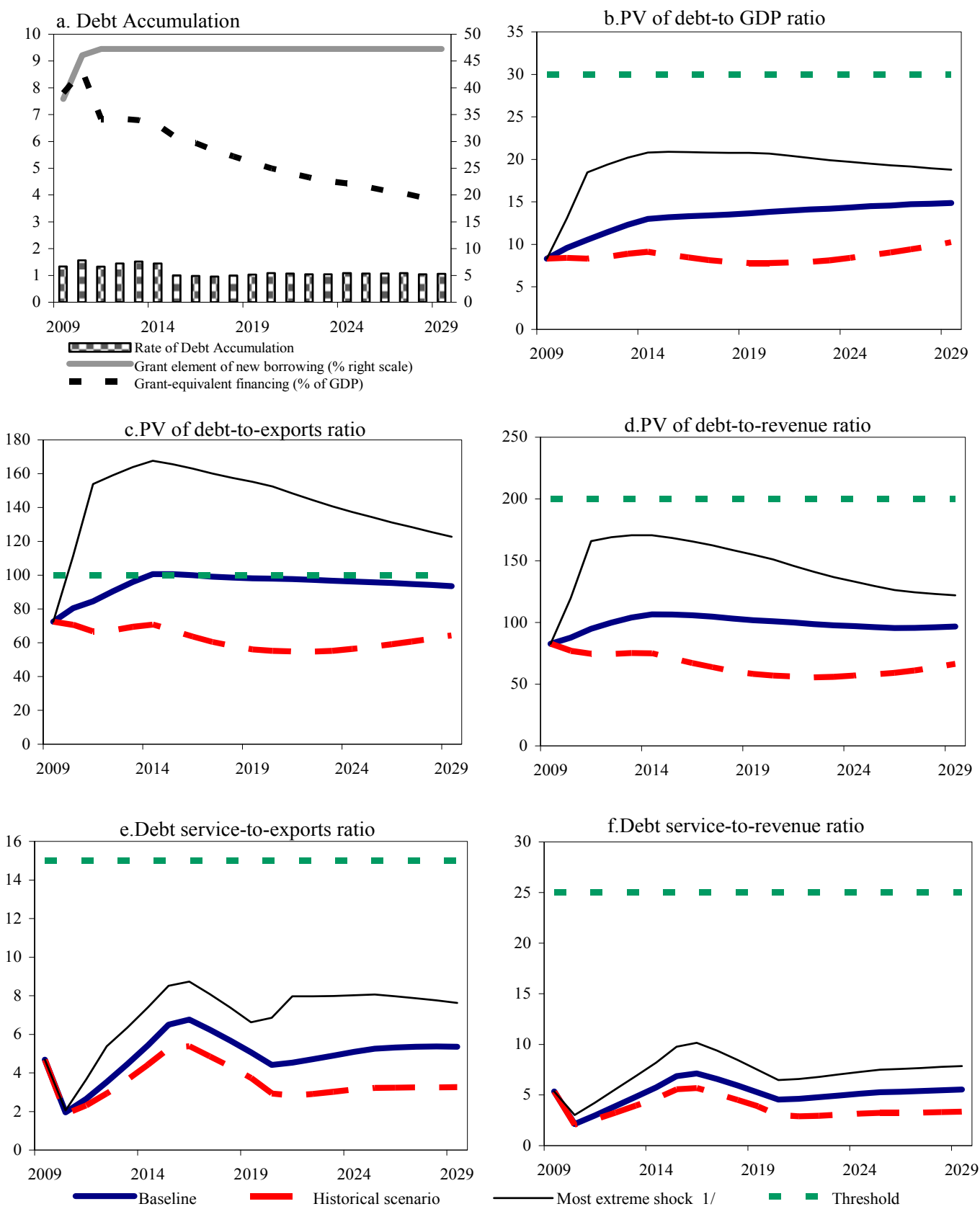

Source: Staff projections and simulations.

1/ The most extreme stress test is the test that yields the highest ratio in 2019. In figure b. it corresponds to a Combination shock; in c. to a Combination shock; in d. to a Combination shock; in e. to a Combination shock and in picture f. to a One-time depreciation shock 
Table A2. Haiti: External Debt Sustainability Framework, Baseline Scenario, 2006-2029 1/

(In percent of GDP, unless otherwise indicated)

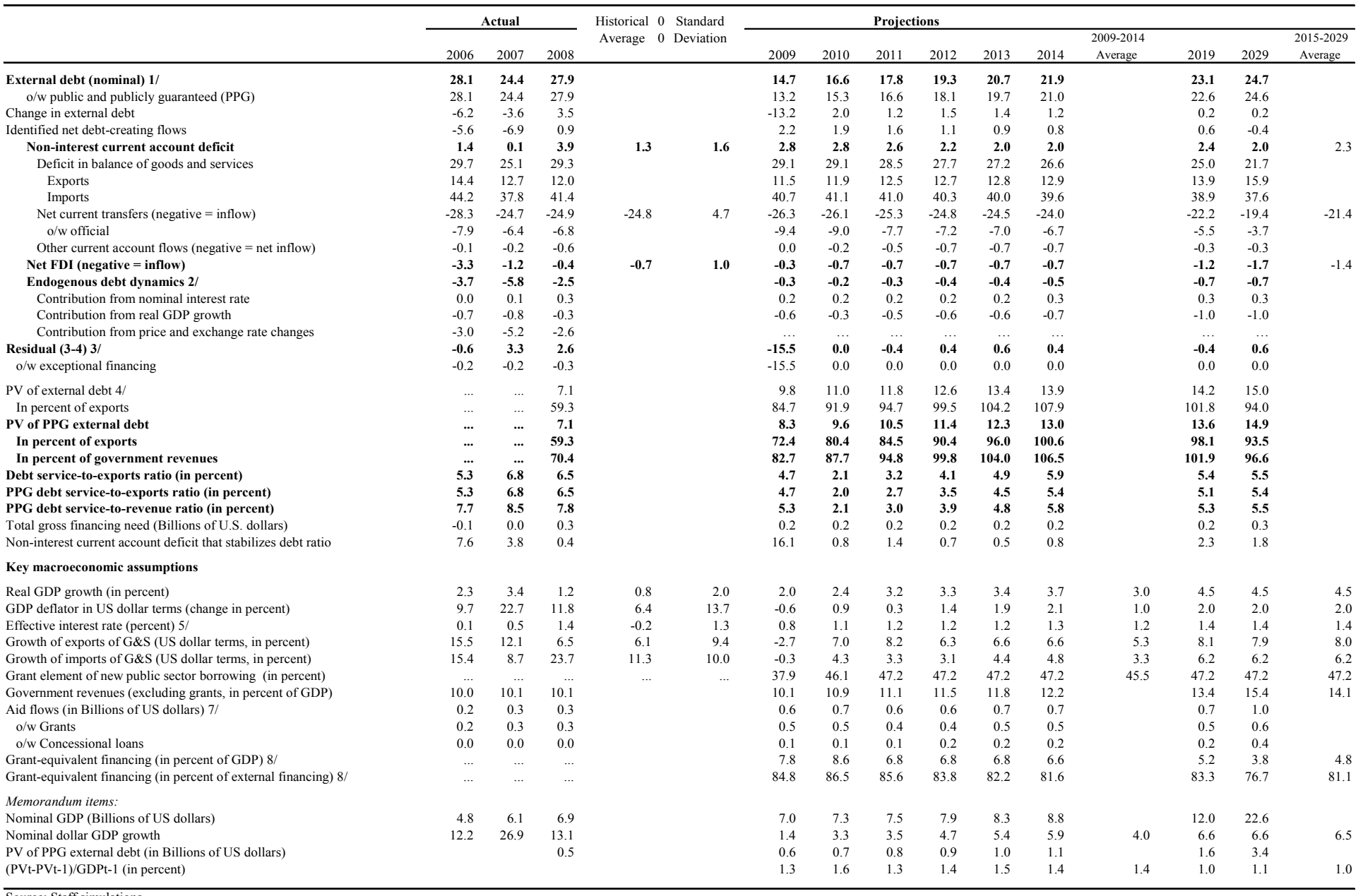

(PVt-PVt-1)/GDPt-1 (in percent)

$1 /$ Includes both public and private sector external debt.

2/ Derived as $[\mathrm{r}-\mathrm{g}-\mathrm{r}(1+\mathrm{g})] /(1+\mathrm{g}+\mathrm{r}+\mathrm{gr})$ times previous period debt ratio, with $\mathrm{r}=$ nominal interest rate; $\mathrm{g}=$ real GDP growth rate, and $\mathrm{r}=$ growth rate of GDP deflator in U.S. dollar terms.

3 / Includes exceptional financing (i.e., changes in arrears and debt relief); changes in gross foreign assets; and valuation adjustments. For projections also includes contribution from price and exchange rate changes.

4/ Assumes that PV of private sector debt is equivalent to its face value.

$6 /$ Historical averages and standard deviations are generally derived over the past 10 years, subject to data availability.

7/ Defined as grants, concessional loans, and debt relief. 


\section{PV of debt-to GDP ratio}

Baseline

Alternative Scenarios

A1. Key variables at their historical averages in 2009-2029 1/

2. New public sector loans on less favorable terms in 2009-2029 2

B. Bound Tests

B1. Real GDP growth at historical average minus one standard deviation in 2010-2011

B. Export value growh at historical average minus one standard deviation in 2010-201

B4. Net non-debt creating flows at historical average minus one standard deviation in 2010-2011

B5. Combination of B1-B4 using one-half standard deviation shocks
B6. One-time 30 percent nominal depreciation relative to the baseline in 2010

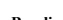

A. Alternative Scenarios

A1. Key variables $t$ thei historical averages in $2009-20291 /$

B. Bound Tests

B1. Real GDP growh at historical average minus one standard deviation in 2010-2011 B2. Export value growth at historical average minus one standard deviation in 2010-2011

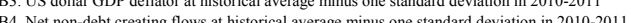
B6. One-time 30 percent nominal depreciation relative to the baseline in $20105 /$

Baseline

A. Alternative Scenarios

A1. Key variables at their historical averages in 2009-2029 1 A2. New public sector loans on less favorable terms in $2009-20292$

B. Bound Tests

B1. Real GDP growth at historical average minus one standard deviation in 2010-2011 B2. Export value growth at historical average minus one standard deviation in 2010-2011 B4. Net non-debt ceeting flows a historiel werage minus one standard devintion in 2010-2011 B5. Combination of B1-B4 using one-half standard deviation shocks
B6. One-time 30 percent nominal depreciation relative to the baseline in 2010

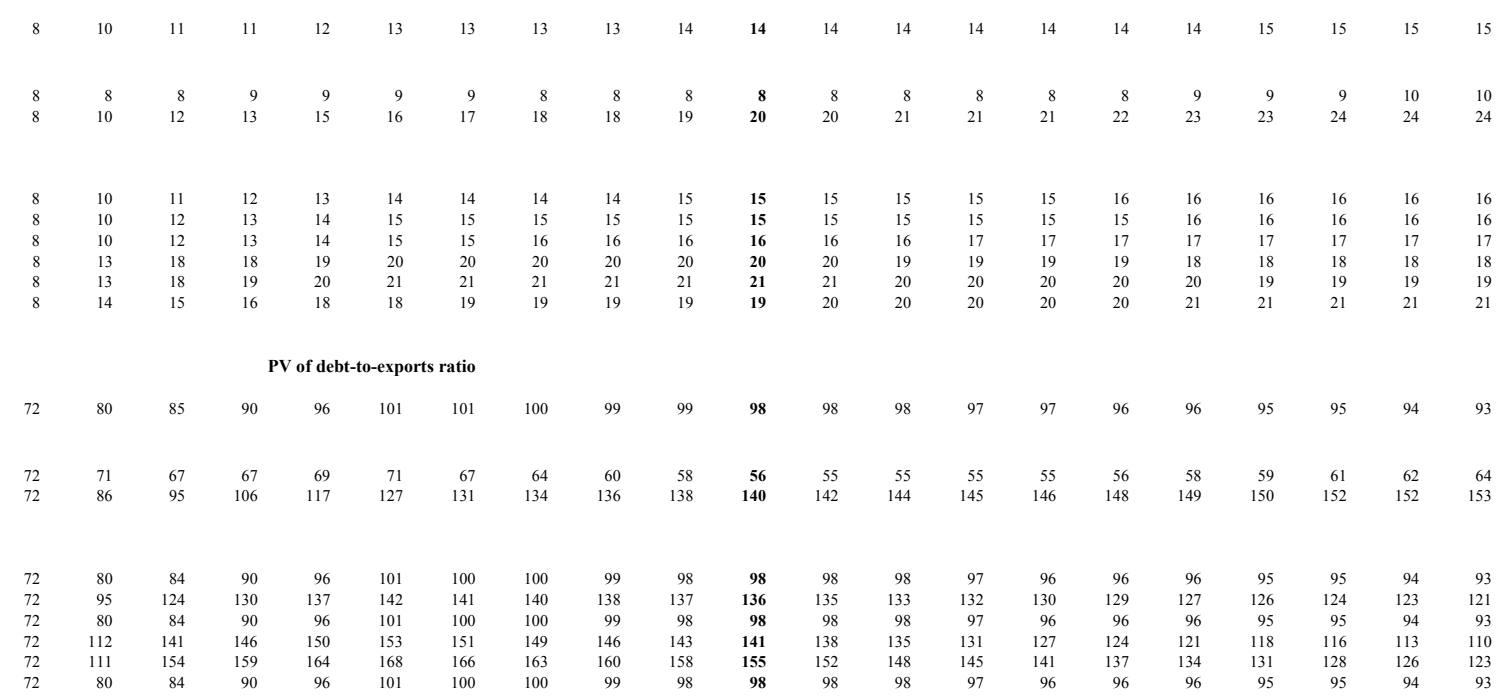

\section{PV of debt-to-revenue ratio}

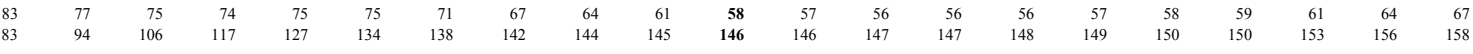

$\begin{array}{lllllllllllllllllllll}83 & 91 & 103 & 108 & 113 & 115 & 115 & 114 & 113 & 112 & 110 & 109 & 108 & 107 & 106 & 105 & 104 & 103 & 103 & 104 & 104 \\ 83 & 93 & 112 & 116 & 120 & 121 & 121 & 120 & 118 & 116 & 114 & 112 & 110 & 108 & 106 & 105 & 103 & 101 & 101 & 101 & 101 \\ 83 & 95 & 111 & 117 & 122 & 125 & 125 & 124 & 123 & 121 & 120 & 119 & 117 & 116 & 115 & 114 & 113 & 112 & 112 & 113 & 113 \\ 83 & 122 & 158 & 161 & 162 & 162 & 160 & 157 & 154 & 150 & 147 & 143 & 138 & 133 & 129 & 125 & 122 & 118 & 116 & 115 & 114 \\ 83 & 120 & 166 & 169 & 171 & 171 & 168 & 166 & 162 & 158 & 155 & 151 & 146 & 141 & 137 & 133 & 130 & 126 & 124 & 123 & 122 \\ 83 & 125 & 135 & 142 & 148 & 151 & 151 & 150 & 149 & 147 & 145 & 143 & 142 & 140 & 139 & 138 & 137 & 135 & 136 & 136 & 137\end{array}$




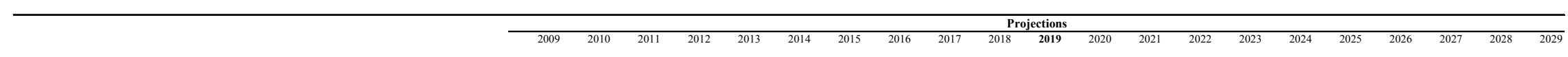

Debt service-to-exports ratio

Baseline

A. Alternative Scenaris

A2. New public sector loans on less favorable terms in 2009 -2029

\section{B. Bound Tests}

B1. Real GDP growth at historical average minus one standard deviation in 2010-2011

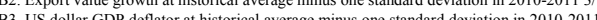

34. Net non-debt creating flows at historical average minus one standard deviation in 2010-2011

B5. Combination of B1-B4 using one-half standard deviation shocks

\section{(1)}

A. Alternative Scenarios

A1. Key variables at their historical averages in 2009-2029 $1 /$

on less favorable terms in 2009-20292

B. Bound Test

B1. Real GDP growth at historical average minus one standard deviation in 2010-2011

B3. US dollar GDP deflator at historical average minus one standard deviation in 2010-2011

34. Net non-debt creating flows at historical average minus one standard deviation in 2010-2011

B5. Combination of B1-B4 using one-half standard deviation shocks
B6. One-time 30 percent nominal depreciation relative to the baseline in $20105 /$

Memorandum item:
Grant element assumed on residual financing (i.e., financing required above baseline) 6

Source: Staff projections and simulations.

1/ Variables ind ing

3/ Exports values are assumed to remain permanently at the lower level, but the current account as a share of GDP is assumed to return to its baseline level after the shock (implicitly assuming

an offsetting adjustment in import levels).

5/ Depreciation is defined as percentage decline in dollar/local currency rate, such that i t never exceeds 100 percent.

6. Applies to all stress scenarios except for A2 (less favorable financing) in which the terms on all new financing are as specified in footnote 2
Debt service-to-revenue ratio

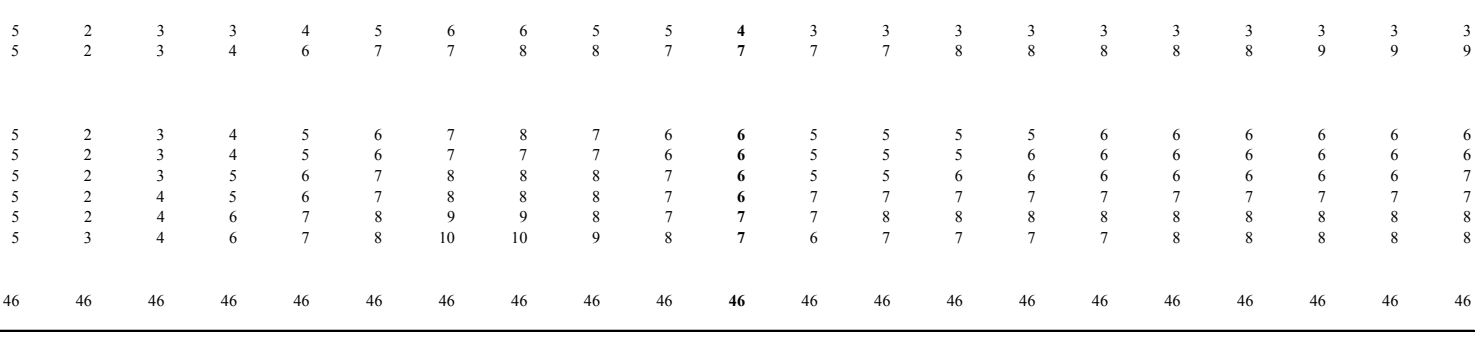


Figure A2.Haiti: Indicators of Public Debt Under Alternative Scenarios, 2009-2029 1/

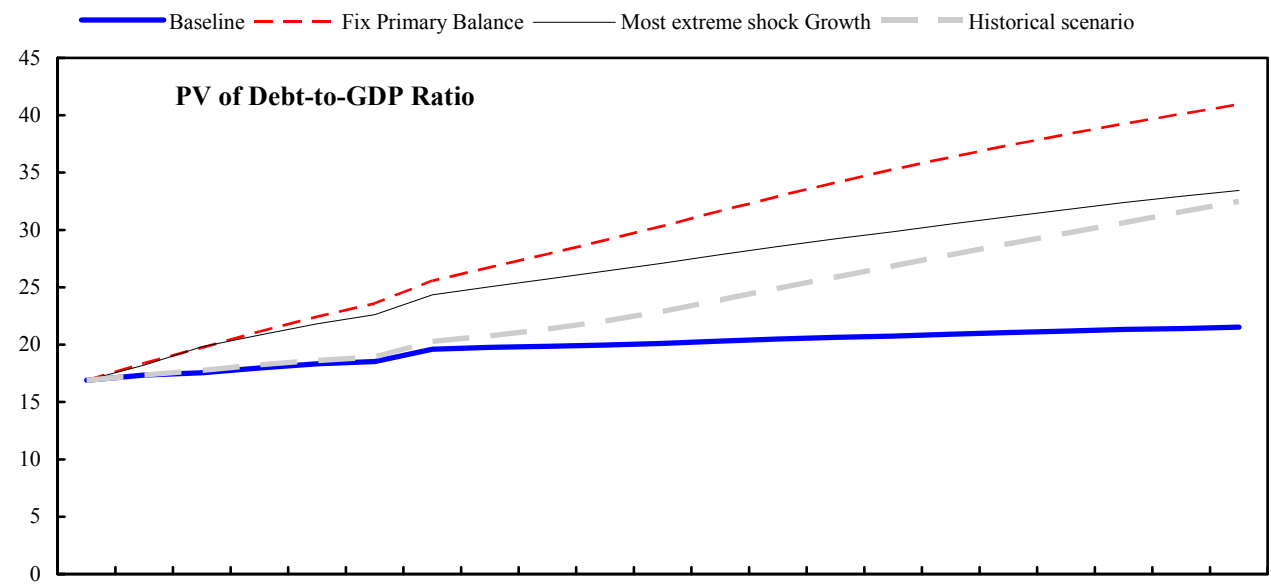

200920102011201220132014201520162017201820192020202120222023202420252026202720282029

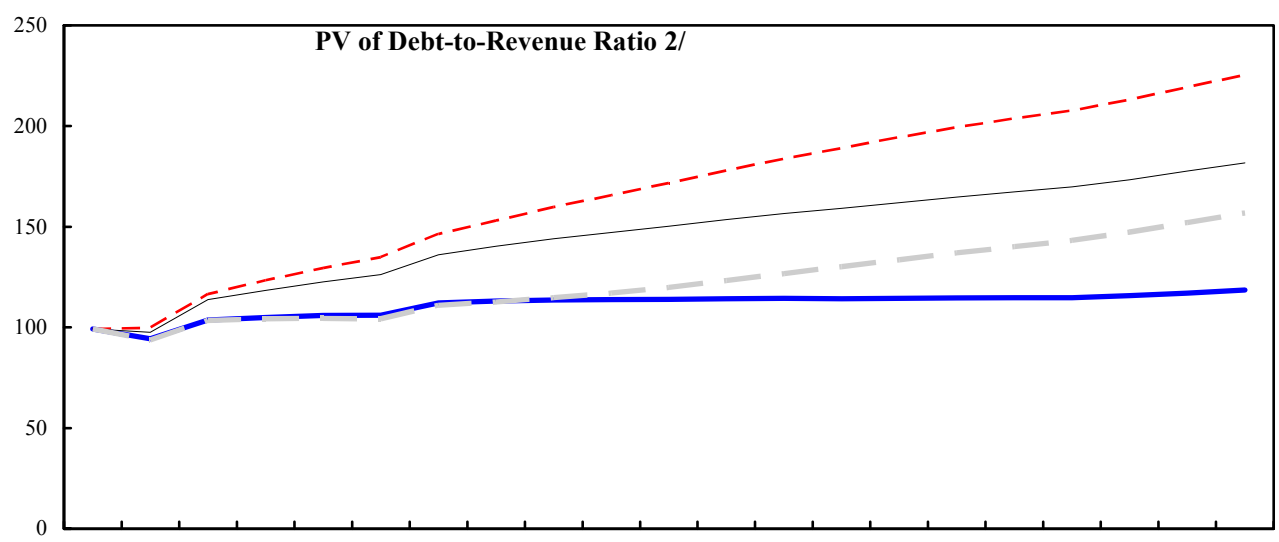

200920102011201220132014201520162017201820192020202120222023202420252026202720282029

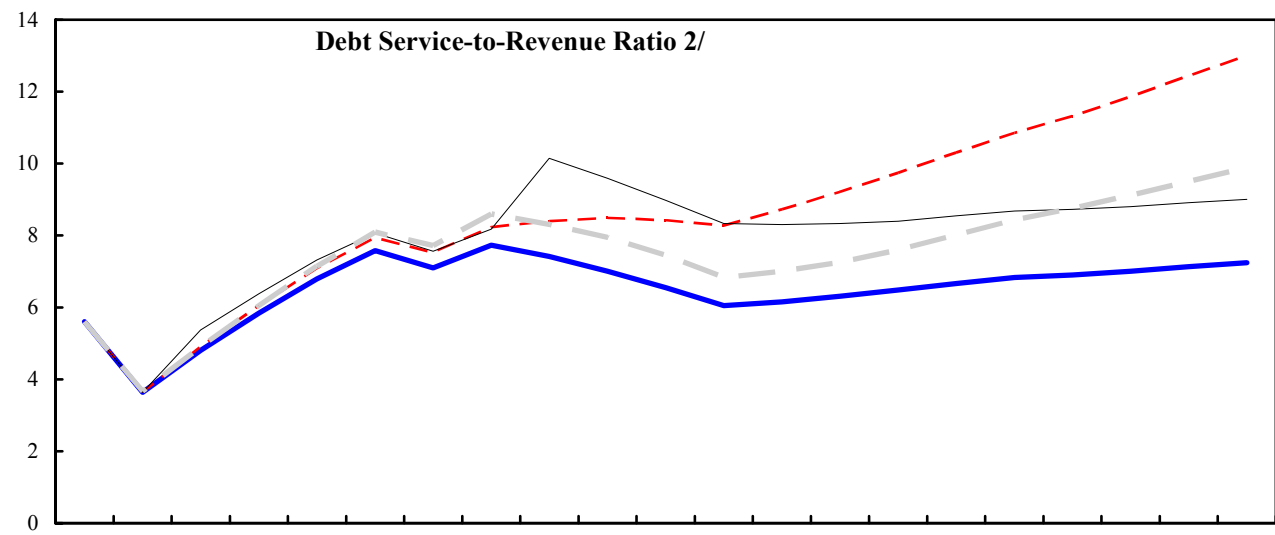

200920102011201220132014201520162017201820192020202120222023202420252026202720282029

Sources: Country authorities; and Fund staff estimates and projections.

$1 /$ The most extreme stress test is the test that yields the highest ratio in 2019.

$2 /$ Revenues are defined inclusive of grants. 
Table A4.Haiti: Public Sector Debt Sustainability Framework, Baseline Scenario, 2006-2029

(In percent of GDP, unless otherwise indicated)

\begin{tabular}{|c|c|c|c|c|c|c|c|c|c|c|c|c|c|c|c|}
\hline & \multicolumn{3}{|c|}{ Actual } & \multirow[b]{2}{*}{ Average } & \multirow[b]{2}{*}{$\begin{array}{c}\text { Standard } \\
\text { Deviation } \\
\end{array}$} & \multicolumn{5}{|l|}{ Estimate } & \multicolumn{5}{|c|}{ Projections } \\
\hline & 2006 & 2007 & 2008 & & & 2009 & 2010 & 2011 & 2012 & 2013 & 2014 & $\begin{array}{l}2009-14 \\
\text { Average }\end{array}$ & 2019 & 2029 & $\begin{array}{l}2015-29 \\
\text { Average } \\
\end{array}$ \\
\hline Public sector debt 1 / & 38.8 & 33.4 & 35.6 & & & 21.5 & 22.7 & 23.4 & 24.4 & 25.5 & 26.3 & & 28.8 & 31.0 & \\
\hline $\mathrm{o} / \mathrm{w}$ foreign-currency denominated & 28.1 & 24.4 & 27.9 & & & 13.2 & 15.3 & 16.6 & 18.1 & 19.7 & 21.0 & & 22.6 & 24.6 & \\
\hline Change in public sector debt & -8.5 & -5.4 & 2.2 & & & -14.1 & 1.2 & 0.7 & 1.0 & 1.0 & 0.8 & & 0.2 & 0.2 & \\
\hline Identified debt-creating flows & -8.7 & -7.1 & 0.4 & & & -12.1 & 1.4 & 1.2 & 1.7 & 1.7 & 1.5 & & 0.4 & 0.3 & \\
\hline Primary deficit & 1.1 & -1.3 & 2.2 & 1.7 & 1.4 & 3.9 & 2.1 & 1.9 & 2.2 & 2.3 & 2.2 & 2.5 & 1.6 & 1.5 & 1.6 \\
\hline Revenue and grants & 13.2 & 15.1 & 14.3 & & & 17.0 & 18.4 & 16.9 & 17.1 & 17.3 & 17.5 & & 17.7 & 18.2 & \\
\hline of which: grants & 3.2 & 5.0 & 4.2 & & & 7.0 & 7.5 & 5.8 & 5.7 & 5.5 & 5.3 & & 4.3 & 2.8 & \\
\hline Primary (noninterest) expenditure & 14.4 & 13.8 & 16.5 & & & 20.9 & 20.5 & 18.9 & 19.3 & 19.6 & 19.7 & & 19.3 & 19.7 & \\
\hline Automatic debt dynamics & -9.8 & -5.8 & -1.8 & & & -0.5 & -0.7 & -0.7 & -0.5 & -0.6 & -0.7 & & -1.2 & -1.3 & \\
\hline Contribution from interest rate/growth differential & -3.5 & -2.1 & -1.4 & & & -0.9 & -0.7 & -0.6 & -0.6 & -0.6 & -0.7 & & -1.2 & -1.3 & \\
\hline of which: contribution from average real interest rate & -2.4 & -0.8 & -1.0 & & & -0.2 & -0.1 & 0.1 & 0.2 & 0.2 & 0.2 & & 0.1 & 0.0 & \\
\hline of which: contribution from real GDP growth & -1.1 & -1.3 & -0.4 & & & -0.7 & -0.5 & -0.7 & -0.7 & -0.8 & -0.9 & & -1.2 & -1.3 & \\
\hline Contribution from real exchange rate depreciation & -6.3 & -3.7 & -0.5 & & & 0.3 & 0.0 & -0.1 & 0.1 & 0.0 & 0.0 & & $\ldots$ & $\ldots$ & \\
\hline Other identified debt-creating flows & 0.0 & 0.0 & 0.0 & & & -15.5 & 0.0 & 0.0 & 0.0 & 0.0 & 0.0 & & 0.0 & 0.0 & \\
\hline Privatization receipts (negative) & 0.0 & 0.0 & 0.0 & & & 0.0 & 0.0 & 0.0 & 0.0 & 0.0 & 0.0 & & 0.0 & 0.0 & \\
\hline Recognition of implicit or contingent liabilities & 0.0 & 0.0 & 0.0 & & & 0.0 & 0.0 & 0.0 & 0.0 & 0.0 & 0.0 & & 0.0 & 0.0 & \\
\hline Debt relief (HIPC and other) & 0.0 & 0.0 & 0.0 & & & -15.5 & 0.0 & 0.0 & 0.0 & 0.0 & 0.0 & & 0.0 & 0.0 & \\
\hline Other (specify, e.g. bank recapitalization) & 0.0 & 0.0 & 0.0 & & & 0.0 & 0.0 & 0.0 & 0.0 & 0.0 & 0.0 & & 0.0 & 0.0 & \\
\hline Residual, including asset changes & 0.2 & 1.6 & 1.8 & & & -1.9 & -0.2 & -0.6 & -0.7 & -0.7 & -0.7 & & -0.2 & -0.1 & \\
\hline \multicolumn{16}{|l|}{ Other Sustainability Indicators } \\
\hline PV of public sector debt & 10.7 & 8.9 & 15.1 & & & 16.9 & 17.4 & 17.6 & 18.0 & 18.3 & 18.5 & & 20.1 & 21.5 & \\
\hline $\mathrm{o} / \mathrm{w}$ foreign-currency denominated & 0.0 & 0.0 & 7.4 & & & 8.7 & 9.9 & 10.7 & 11.7 & 12.6 & 13.2 & & 13.9 & 15.2 & \\
\hline $\mathrm{o} / \mathrm{w}$ external & $\ldots$ & $\ldots$ & 7.4 & & & 8.7 & 9.9 & 10.7 & 11.7 & 12.6 & 13.2 & & 13.9 & 15.2 & \\
\hline PV of contingent liabilities (not included in public sector debt) & $\ldots$ & & $\ldots$ & & & $\ldots$ & $\ldots$ & $\ldots$ & $\ldots$ & $\ldots$ & $\ldots$ & & & & \\
\hline Gross financing need $2 /$ & 13.2 & 9.7 & 11.0 & & & 11.9 & 10.2 & 9.6 & 9.5 & 9.3 & 8.8 & & 8.4 & 8.6 & \\
\hline $\mathrm{PV}$ of public sector debt-to-revenue and grants ratio (in percent) & 80.7 & 59.0 & 105.8 & & & 99.2 & 94.2 & 103.7 & 104.9 & 105.9 & 106.1 & & 113.9 & 118.5 & \\
\hline $\mathrm{PV}$ of public sector debt-to-revenue ratio (in percent) & 106.6 & 88.3 & 149.4 & & & 167.6 & 158.7 & 157.8 & 156.7 & 154.9 & 152.0 & & 150.2 & 139.8 & \\
\hline o/w external 3/ & & & 73.5 & & & 85.8 & 90.7 & 96.4 & 101.8 & 106.1 & 108.6 & & 103.9 & 98.5 & \\
\hline Debt service-to-revenue and grants ratio (in percent) $4 /$ & 9.0 & 10.6 & 7.7 & & & 5.6 & 3.6 & 4.8 & 5.8 & 6.8 & 7.6 & & 6.5 & 7.2 & \\
\hline Debt service-to-revenue ratio (in percent) 4/ & 11.8 & 15.8 & 10.9 & & & 9.5 & 6.1 & 7.3 & 8.7 & 9.9 & 10.9 & & 8.6 & 8.5 & \\
\hline Primary deficit that stabilizes the debt-to-GDP ratio & 9.6 & 4.1 & 0.0 & & & 18.0 & 0.9 & 1.3 & 1.2 & 1.3 & 1.4 & & 1.4 & 1.3 & \\
\hline \multicolumn{16}{|l|}{ Key macroeconomic and fiscal assumptions } \\
\hline Real GDP growth (in percent) & 2.3 & 3.4 & 1.2 & 0.8 & 2.0 & 2.0 & 2.4 & 3.2 & 3.3 & 3.4 & 3.7 & 3.0 & 4.5 & 4.5 & 4.5 \\
\hline Average nominal interest rate on forex debt (in percent) & 0.1 & 0.5 & 1.4 & -0.2 & 1.3 & 0.8 & 1.2 & 1.2 & 1.2 & 1.3 & 1.4 & 1.2 & 1.5 & 1.4 & 1.4 \\
\hline Average real interest rate on domestic debt (in percent) & -10.9 & -2.5 & -9.0 & -9.3 & 5.3 & -0.5 & -2.2 & 1.5 & 3.4 & 5.0 & 6.2 & 2.2 & 2.9 & 2.9 & 2.9 \\
\hline Real exchange rate depreciation (in percent, + indicates depreciation) & -19.5 & -13.7 & -1.9 & -6.8 & 14.3 & 1.2 & & $\ldots$ & $\ldots$ & $\ldots$ & $\ldots$ & $\ldots$ & $\ldots$ & $\ldots$ & \\
\hline Inflation rate (GDP deflator, in percent) & 16.6 & 10.7 & 14.4 & 14.7 & 6.0 & 6.3 & 8.3 & 5.5 & 5.2 & 5.2 & 5.2 & 5.9 & 5.0 & 5.0 & 5.0 \\
\hline Growth of real primary spending (deflated by GDP deflator, in percent) & -0.1 & 0.0 & 0.2 & 0.1 & 0.2 & 0.3 & 0.0 & -0.1 & 0.1 & 0.1 & 0.0 & 0.1 & 0.0 & 0.0 & 0.0 \\
\hline Grant element of new external borrowing (in percent) & $\ldots$ & $\ldots$ & $\ldots$ & $\ldots$ & $\ldots$ & 37.9 & 46.1 & 47.2 & 47.2 & 47.2 & 47.2 & 45.5 & 47.2 & 47.2 & $\ldots$ \\
\hline
\end{tabular}

/ Includes gross external debt of or guaranteed by the central government and central bank, and gross domestic debt of the central government.

$2 /$ Gross financing need is defined as the primary deficit plus debt service plus the stock of short-term debt at the end of the last period.

3/ Revenues excluding grants.

4/ Debt service is defined as the sum of interest and amortization of medium and long-term debt.

5/ Historical averages and standard deviations are generally derived over the past 10 years, subject to data availability. 


\begin{tabular}{|c|c|c|c|c|c|c|c|c|}
\hline & \multicolumn{8}{|c|}{ Projections } \\
\hline & 2009 & 2010 & 2011 & 2012 & 2013 & 2014 & 2019 & 2029 \\
\hline \multicolumn{9}{|c|}{ PV of Debt-to-GDP Ratio } \\
\hline Baseline & 17 & 17 & 18 & 18 & 18 & 19 & 20 & 22 \\
\hline \multicolumn{9}{|l|}{ A. Alternative scenarios } \\
\hline A1. Real GDP growth and primary balance are at historical averages & 17 & 17 & 18 & 18 & 19 & 19 & 23 & 32 \\
\hline A2. Primary balance is unchanged from 2009 & 17 & 18 & 20 & 21 & 22 & 24 & 30 & 41 \\
\hline \multicolumn{9}{|l|}{ B. Bound tests } \\
\hline B1. Real GDP growth is at historical average minus one standard deviations in 2010-2011 & 17 & 18 & 20 & 21 & 22 & 23 & 27 & 33 \\
\hline B2. Primary balance is at historical average minus one standard deviations in $2010-2011$ & 17 & 18 & 19 & 19 & 20 & 20 & 21 & 22 \\
\hline B3. Combination of B1-B2 using one half standard deviation shocks & 17 & 18 & 19 & 20 & 21 & 21 & 25 & 30 \\
\hline B4. One-time 30 percent real depreciation in 2010 & 17 & 21 & 21 & 21 & 20 & 20 & 21 & 22 \\
\hline B5. 10 percent of GDP increase in other debt-creating flows in 2010 & 17 & 23 & 23 & 24 & 24 & 24 & 25 & 24 \\
\hline Baseline & 99 & 94 & 104 & 105 & 106 & 106 & 114 & 118 \\
\hline \multicolumn{9}{|l|}{ A. Alternative scenarios } \\
\hline A1. Real GDP growth and primary balance are at historical averages & 99 & 94 & 103 & 104 & 104 & 104 & 120 & 157 \\
\hline A2. Primary balance is unchanged from 2009 & 99 & 100 & 117 & 123 & 130 & 135 & 172 & 225 \\
\hline A3. Permanently lower GDP growth $1 /$ & 99 & 95 & 105 & 107 & 109 & 110 & 127 & 165 \\
\hline \multicolumn{9}{|l|}{ B. Bound tests } \\
\hline B1. Real GDP growth is at historical average minus one standard deviations in 2010-2011 & 99 & 98 & 114 & 118 & 123 & 126 & 150 & 182 \\
\hline B2. Primary balance is at historical average minus one standard deviations in $2010-2011$ & 99 & 97 & 111 & 112 & 113 & 113 & 120 & 122 \\
\hline B3. Combination of B1-B2 using one half standard deviation shocks & 99 & 96 & 109 & 113 & 117 & 119 & 140 & 164 \\
\hline B4. One-time 30 percent real depreciation in 2010 & 99 & 114 & 122 & 120 & 118 & 116 & 118 & 121 \\
\hline B5. 10 percent of GDP increase in other debt-creating flows in 2010 & 99 & 126 & 138 & 139 & 139 & 139 & 141 & 134 \\
\hline
\end{tabular}

Debt Service-to-Revenue Ratio 2/

Baseline

\section{A. Alternative scenarios}

A1. Real GDP growth and primary balance are at historical averages

A2. Primary balance is unchanged from 2009

A3. Permanently lower GDP growth 1/

$\begin{array}{rrrrrrrr}6 & 4 & 5 & 6 & 7 & 8 & 7 & 10 \\ 6 & 4 & 5 & 6 & 7 & 8 & 8 & 13 \\ 6 & 4 & 5 & 6 & 7 & 8 & 7 & 9\end{array}$

\section{B. Bound tests}

B1. Real GDP growth is at historical average minus one standard deviations in 2010-2011

B2. Primary balance is at historical average minus one standard deviations in 2010-2011

B3. Combination of B1-B2 using one half standard deviation shocks

B4. One-time 30 percent real depreciation in 2010

B5. 10 percent of GDP increase in other debt-creating flows in 2010

$\begin{array}{rrrrrrrr}6 & 4 & 5 & 6 & 7 & 8 & 8 & 11 \\ 6 & 4 & 5 & 6 & 7 & 8 & 7 & 8 \\ 6 & 4 & 5 & 6 & 7 & 8 & 7 & 10 \\ 6 & 4 & 6 & 7 & 8 & 10 & 9 & 10 \\ 6 & 4 & 5 & 6 & 7 & 8 & 9 & 9\end{array}$

Sources: Country authorities; and Fund staff estimates and projections.

1/ Assumes that real GDP growth is at baseline minus one standard deviation divided by the square root of the length of the projection period.

2/ Revenues are defined inclusive of grants. 